\title{
Human Gut Microbiota in Health and Selected Cancers
}

\author{
Aleksandra Sędzikowska (1) and Leszek Szablewski *
}

\footnotetext{
check for updates

Citation: Sẹdzikowska, A.;

Szablewski, L. Human Gut

Microbiota in Health and Selected Cancers. Int. J. Mol. Sci. 2021, 22, 13440. https://doi.org/10.3390/ ijms222413440
}

Academic Editors: Federica Laudisi and Carmine Stolfi

Received: 25 November 2021 Accepted: 10 December 2021 Published: 14 December 2021

Publisher's Note: MDPI stays neutral with regard to jurisdictional claims in published maps and institutional affiliations.

Copyright: (c) 2021 by the authors. Licensee MDPI, Basel, Switzerland. This article is an open access article distributed under the terms and conditions of the Creative Commons Attribution (CC BY) license (https:/ / creativecommons.org/licenses/by/ $4.0 /)$.
Chair and Department of General Biology and Parasitology, Medical University of Warsaw, ul. Chalubinskiego 5 , 02-004 Warsaw, Poland; aleksandra.sedzikowska@wum.edu.pl

* Correspondence: leszek.szablewski@wum.edu.pl; Tel.: +48-22-621-2607

\begin{abstract}
The majority of the epithelial surfaces of our body, and the digestive tract, respiratory and urogenital systems, are colonized by a vast number of bacteria, archaea, fungi, protozoans, and viruses. These microbiota, particularly those of the intestines, play an important, beneficial role in digestion, metabolism, and the synthesis of vitamins. Their metabolites stimulate cytokine production by the human host, which are used against potential pathogens. The composition of the microbiota is influenced by several internal and external factors, including diet, age, disease, and lifestyle. Such changes, called dysbiosis, may be involved in the development of various conditions, such as metabolic diseases, including metabolic syndrome, type 2 diabetes mellitus, Hashimoto's thyroidis and Graves' disease; they can also play a role in nervous system disturbances, such as multiple sclerosis, Alzheimer's disease, Parkinson's disease, and depression. An association has also been found between gut microbiota dysbiosis and cancer. Our health is closely associated with the state of our microbiota, and their homeostasis. The aim of this review is to describe the associations between human gut microbiota and cancer, and examine the potential role of gut microbiota in anticancer therapy.
\end{abstract}

Keywords: gut microbiota; modulators of gut microbiota; dysbiosis; cancers; anticancer therapy

\section{Introduction}

The gut microbiota comprises the organisms that live in the gastrointestinal (GI) tract. The adult human gut microbiota consists of $10^{13}-10^{14}$ microorganisms $/ \mathrm{mL}$ of luminal content, with their total weight estimated to be $1.5 \mathrm{~kg}$ [1]. The human gut microbiota is composed of bacteria, archaea, fungi, protozoa, and viruses, in which bacteria dominate. The genome of the human microbiota includes 100 times more genes than the human genome and 10 times more cells than the human body [2]. The human microbiota is characterized by three groups of bacteria, viz. symbionts, commensals and pathobionts, which coexist in a stable balance in healthy humans. Symbionts possess a health-promoting effect, commensals demonstrate a neutral effect, i.e., no positive and no negative, whereas pathobionts have the potential to induce pathology [3].

Human microbiota, especially those of the gut, may have a beneficial effect on human health, and may be involved in serious metabolic diseases, autoimmune diseases, and those of the human nervous system. Gut microbiota may also play an important role in the development and progression of cancer disease.

The role of gut microbiota in human health is investigated and described in different aspects. Gut bacteria synthesize the compounds necessary for human health, such as vitamins and amino acids, short-chain fatty acids, and secondary bile acids. These bacteria also synthesize neurotransmitters and neuropeptides, as well as playing a protective function. On the other hand, changes in the composition of gut microbiota, called dysbiosis, may cause several diseases. The correlation between dysbiosis and metabolic diseases and psychiatric diseases or disorders is well described in literature. Less is known on dependence on changes of gut microbiota in the development and/or progression of cancers. Moreover, the literature on the role of gut microbiota as a target in anti-cancer 
therapy is very poor. Therefore, we describe how gut microbiota may be associated with cancer diseases. We present more recent and important results obtained in research involved in this problem.

The dependence between microbiota and health, as well as disease, was observed a long, long time ago. Hippocrates, Father of Medicine, in fourth century BC, wrote "All disease begins in the gut". Louis Pasteur, French chemist and microbiologist, honored as the Father of Bacteriology, and as the Father of Microbiology, has seen the important influence of bacteria on human health and disease. Therefore, he wrote "Gentlemen, it is the microbes who will have the last word" "Messieurs, c'est les microbes qui auront the dernier mot". René Dubos, a French-American microbiologist, also observed the abovementioned dependence. He wrote "The states of health or disease are the expression of the success or failure experienced by the organism in its efforts to respond adaptively to environmental challenges". René Dubos is often attributed as the author of the environmental maxim: "Think globally, act locally".

The idea that microbes can promote the development of cancers is old, and acquired a certain popularity in the late 1980s and early 1900s in the context of experiments and observations that were later disproven. Several recent studies have analyzed the oral and gut microbial dysbiosis associated with cancer risk and progression. In this review, we highlight studies analyzing the role of gut microbiota in human health and diseases, especially in cancer cells. We describe the association between changes of human gut microbiota and the development of selected cancers. We also discuss various strategies for microbial modulation. Additionally, we also summarize the potential role as a target in anticancer therapy.

\section{Composition and Distribution of Human Microbiota}

The human gut contains approximately 1000 different species of bacteria. To date, 50 phyla of bacteria have been described [4], four of which dominate in human gut microbiota: Bacteroidetes (Gram-negative bacteria), Firmicutes (Gram-positive, aerobic and anaerobic bacteria), Proteobacteria (for example the genera Escherichia and Enterobacter), and Actinobacteria (for example Bifidobacterium). Of these, the predominant phyla, accounting for up to 70 to $90 \%$ of total bacteria, are Firmicutes (60-80\%), with more than 200 genera, the most important being Ruminococcus, Clostridium, Eubacterium, Faecalibacterium, Roseburia, and Mycoplasma, and the Bacteroidetes (20-30\%), with the genera Bacteroides, Prevotella, and Xylanibacter [5]. Of the remainder, the Actinobacteria and Proteobacteria both constitute less than 10, and the minor phyla Fusobacteria and Verrucomicrobia occur relatively rarely $[6,7]$. In addition to the human gut, they are known to colonize various compartments of the human body. For example, various lipophilic bacteria, such as Propionibacterium spp. and Malassezia spp., are present in human skin [8,9].

A number of fungi also colonize the human body. The human gastrointestinal tract has been found to contain 66 fungal genera, including 184 fungal species [10]. In addition, the oral cavity is known to contain fungi belonging to the phylum Ascomycota, such as Candida spp., Fusarium spp., as well as various species of Saccharomycetaceae, such as Candida albicans, C. dubliniensis, C. rugose and C. pararugosa, as well as Saccharomyces cerevisiae, Hanseniaspora uvarum and Pichia spp. [11,12]. The human gastrointestinal tract is home to several fungal species from the genera Candida, Saccharomyces, Aspergillus, Cryptococcus, Malassezia, Cladosporium, Galactomyces and Trichosporon [13]. Other studies have also reported the presence of the genera Candida, Aspergillus, Penicillium, Eremothecium, Trichospora, Cladosporium, Epicoccum, and Cryptococcus in the human mouth, Candida in the stomach, and the genera Aspergillus, Malassezia, Trichosporon, Eremothecium, Cladosporium, Saccharomyces, Candida, Cryptococcus and Galactomyces in the intestine, between the duodenum and colon [14,15]. Species of Aspergillus, Penicillium, and Candida have been identified in the lungs of healthy humans [11,12,16], and Candida albicans, C. glabrata, C. krusei, C. parapsilosis and Saccharomyces cerevisiae in the vagina of healthy women are low $[17,18]$. 
The composition of the human microbiota is not homogenous throughout the body; its precise makeup at any location depends on a range of factors such as the organ, region of the GI or type of bacteria, among others (Table 1). It is also strongly influenced systematically by the mode of delivery at birth, age, sex, ethnicity, diet, diseases, use of antibiotics and other pharmaceuticals, as well as probiotics and prebiotics. It is also important to consider that the bacteria of the human microbiota may play various roles, and they can be beneficial as well as pathological (Table 2).

Table 1. The composition and concentrations of microbiota in healthy human digestive tract with regard to body parts. The concentration of bacteria is presented as number of cells per gram of luminal content $[3,14,15,19]$.

\begin{tabular}{|c|c|c|}
\hline Region of Digestive Tract & $\begin{array}{l}\text { Concentrations } \\
\text { of Microbiota }\end{array}$ & Composition of the Microbiota Families/Genus (Species) \\
\hline Mouth & $10^{12}$ & $\begin{array}{c}\text { Lactobacillus, Streptococcus, Helicobacter pylori, } \\
\text { Peptostreptococcus, Veillonella }\end{array}$ \\
\hline Stomach & $0-10^{4}$ & $\begin{array}{l}\text { Lactobacillus, Streptococcus, Helicobacter pylori, } \\
\text { Peptostreptococcus, Veillonella }\end{array}$ \\
\hline Duodenum & $10^{2}-10^{3}$ & $\begin{array}{c}\text { Streptococcus, Lactobacillus, Bacilli, Actinobacteria, } \\
\text { Actinomycinaeae, Corynobacteriaceae }\end{array}$ \\
\hline Jejunum & $10^{2}-10^{6}$ & $\begin{array}{c}\text { Streptococcus, Lactobacillus, Bacilli, Actinobacteria, } \\
\text { Actinomycinaeae, Corynobacteriaceae }\end{array}$ \\
\hline Proximal ileum & $10^{3}$ & $\begin{array}{c}\text { Streptococcus, Lactobacillus, Bacilli, Actinobacteria, } \\
\text { Actinomycinaeae, Corynobacteriaceae }\end{array}$ \\
\hline $\begin{array}{l}\text { Distal } \\
\text { ileum }\end{array}$ & $10^{7}-10^{8}$ & $\begin{array}{c}\text { Clostridium, Streptococcus, Bacteroides, Actinomycinaeae, } \\
\text { Corynobacteria }\end{array}$ \\
\hline Colon & $10^{10}-10^{12}$ & $\begin{array}{c}\text { Bacteroides, Clostridium clusters IV and V, Bifidobacterium, } \\
\text { Enterobacteriaceae, Lachnospiraceae, Propionibacterium, } \\
\text { Lactobacillus, Escherichia coli }\end{array}$ \\
\hline
\end{tabular}

Table 2. Roles of selected human gut bacteria. For details, please see [2,10,15,20].

\begin{tabular}{|c|c|}
\hline Bacteria & Role in Human Body \\
\hline Bifidobacterium spp. & $\begin{array}{l}\text { Produces short-chain fatty acids, improves gut mucosal barrier, decreases } \\
\text { lipopolysaccharide levels. Some species used as probiotics. }\end{array}$ \\
\hline Bacteroides spp. & $\begin{array}{l}\text { Involved in immunity by activation of } \mathrm{CD}^{+} \mathrm{T} \text { cells. Some species exclude potential } \\
\text { pathogens from the human gut, however, others are opportunistic human pathogens. }\end{array}$ \\
\hline Lactobacillus spp. & $\begin{array}{l}\text { Produces short-chain fatty acids. Plays a role in anti-cancer and anti-inflammatory } \\
\text { processes, produces and releases hydrogen peroxide which inhibits the growth and } \\
\text { virulence of the fungal pathogen Candida albicans; some species are used as probiotics. }\end{array}$ \\
\hline Bilophila spp. & $\begin{array}{l}\text { These bacteria are involved in immunity by activation of Th1 cells. Some species are } \\
\text { detected in perforated and gangrenous appendicitis. }\end{array}$ \\
\hline Clostridium spp. & $\begin{array}{l}\text { These species promote generation of Th17 cells, however some species of this genus are } \\
\text { significant human pathogens, causing botulism and diarrhea. }\end{array}$ \\
\hline Roseburia spp. & $\begin{array}{l}\text { These species produce short-chain fatty acids. This genus produces butyrate, which plays } \\
\text { several beneficial roles in human body. }\end{array}$ \\
\hline Eubacterium spp. & $\begin{array}{l}\text { These species produce short-chain fatty acids (butyrate-producing bacteria). Some species } \\
\text { may cause bacterial vaginosis. }\end{array}$ \\
\hline Enterococcus spp. & $\begin{array}{l}\text { These species may cause urinary tract infections, bacteremia, bacterial endocarditis and } \\
\text { diverticulitis meningitis. }\end{array}$ \\
\hline Faecalibacterium prausnitzi & $\begin{array}{c}\text { This species produces short-chain fatty acids, plays an anti-inflammatory role and boosts } \\
\text { the immune system. }\end{array}$ \\
\hline
\end{tabular}


Table 2. Cont.

\begin{tabular}{|c|c|}
\hline Bacteria & Role in Human Body \\
\hline Akkermansia muciniphila & This species shows anti-inflammatory effects; it degrades human intestinal mucin. \\
\hline Escherichia coli & It activates Toll-like receptors and synthesizes vitamin $K_{2}$. \\
\hline Helicobacter pylori & This species may cause peptic ulcer disease and gastric cancer. \\
\hline Streptococcus spp. & $\begin{array}{l}\text { Some species may cause scarlet fever, rheumatic heart disease, glomerulonephritis, } \\
\text { pneumococcal pneumonia. }\end{array}$ \\
\hline Prevotella spp. & $\begin{array}{c}\text { The species of this genus may cause anaerobic infections of the respiratory tract and } \\
\text { predominate in periodontal disease and abscess. }\end{array}$ \\
\hline Staphylococcus spp. & $\begin{array}{l}\text { These bacteria reside normally on the skin and mucous membranes in humans and are } \\
\text { responsible for several common infections. }\end{array}$ \\
\hline Corynebacterium spp. & Some species can cause diseases, such as diphtheria. \\
\hline Egerthella lenta & This species is associated with abdominal sepsis. \\
\hline Xylanibacter spp. & These species increases fecal short-chain fatty acid levels. \\
\hline Enterobacteriaceae & $\begin{array}{c}\text { This family includes symbionts and pathogens, such as Salmonella, Yersinia } \\
\text { pestis, and Shigella. }\end{array}$ \\
\hline
\end{tabular}

\section{The Role of Gut Microbiota in Human Health}

The human gut microbiota is involved in several processes that influence human health. Its microbiological components synthesize a range of compounds necessary for human health, such as vitamins, amino acids, and several other small molecules that may be absorbed into the circulating system. The absorbed molecules affect cellular processes, such as gene expression, differentiation, proliferation, and apoptosis [21].

\subsection{Gut Microbiota and Short-Chain Fatty Acids}

The microbiota that live in the human cecum and colon can produce carbohydrateactive enzymes that ferment non-digestible carbohydrates such as cellulose, xylans, and inulin to generate short-chain fatty acids (SCFAs) [22]; of these, propionate $\left(\mathrm{C}_{3}\right)$, butyrate $\left(\mathrm{C}_{4}\right)$, and acetate $\left(\mathrm{C}_{2}\right)$ acid predominate in the ratio 1:1:3 [21]. These SCFAs are rapidly absorbed by epithelial cells in the gastrointestinal tract. The bacteria also synthesize and release isobutyrate and hexonate [23]. Of the SCFAs, acetate is released by most anaerobic bacteria, and propionate and butyrate by various subsets of gut microbiota. In addition, the bacteria of the human colon synthesize propionate from sugars via the succinate or propanediol pathway, or butyrate via glycolysis [24].

The gut microbiota has been estimated to produce $50-100 \mathrm{mmol} / \mathrm{L} /$ day of SCFAs, and that up to $95 \%$ of this serves as an energy source for colonocytes [25]. Particular SCFAs play several roles in humans. Butyrate is involved in anti-inflammation and anticancer processes [26]. It influences tight-junction assembly and mucin synthesis, thus enhancing gut barrier function and attenuating bacterial translocation [26]. Butyrate and acetate are inhibitors of histone deacetylase [27], resulting in histone hyperacetylation, altered gene expression, anti-inflammatory properties, the induction of growth arrest and apoptosis [28]; thus, the microbiota can influence the proliferation and differentiation of human colonic epithelial cells, and their gene expression, via butyrate and acetate production. It is believed that these SCFAs could regulate $2 \%$ of the mammalian transcriptome [29]. The inhibition of histone deacetylase activity by SCFAs also stimulates non-histone proteins, such as nuclear factor-kappa B (NFkB), MyoD, a transcription factor that could reprogram fibroblasts into skeletal muscle cells, p53 and the nuclear factor of activated T cells (NFAT), which can modulate gene expression [30]. Butyrate also inhibits the expression of pro-inflammatory mediators, such as interleukin $1 \beta$ (IL- $\beta$ ), IL-6, IL-12, tumor necrosis factor- $\alpha$ (TNF- $\alpha$ ), nitric oxide (NO) and interferon- $\gamma$ (IFN- $\gamma$ ), but increases the release of anti-inflammatory IL-10 [30], which stimulates the expression of intestinal epithelial cytoprotective shock 
proteins (HSPs) 25 and 72 [31]. In addition, elevated levels of butyrate and propionate also activate intestinal gluconeogenesis via the gut-brain neural circuit [32]. Generally speaking, the SFCAs released by colonic bacteria are known to play a wide range of functions in the human body, including as signaling molecules [15].

\subsection{Gut Microbiota and Bile Acids}

The gut microbiota is known to synthesize secondary bile acids (BAs), deoxycholic acid (DCA), ursedeoxycholic acid (UDCA) and lithocholic acid (LCA) from cholesterol derived from the human liver [33]. This process takes place in the distal small intestine and colon [34]. The synthesized primary bile acids are conjugated to glycine and taken up in the distal ileum for transport to the liver. These bile acids are deconjugated by bacteria in the distal ileum and colon, and are then further metabolized by gut microbiota into secondary bile acids [20], such as deoxycholic acid (DCA) and litocholic acid (LCA). Like SCFAs, bile acids play several roles in the human body. They are naturally occurring detergents that help in the absorption of dietary fats. They also act as signal molecules: BAs bind to cellular receptors such as the farnesoid $X$ receptor (FXR) [35] and G protein-coupled receptors, such as $\mathrm{G}$ protein-coupled bile acid receptor (TGR5), also known as a membrane-type receptor for bile acids (M-BAR) [20]. The activation of FXR, by primary bile acids, and TGR by secondary bile acids [20] influences the glucose metabolism: TGR5 activation stimulates cyclic adenosine monophosphate (cAMP) synthesis, which activates protein kinase A (PKA); FXR activation impairs glucose homeostasis, whereas the activation of TGR promotes it [36]. Results obtained in animal studies indicate that the stimulation of TGR5 stimulates the secretion of glucagon-like peptide 1 (GLP-1) from L-cells, enhances glucose tolerance in obese mice [37], and in brown adipose tissue and muscle, increases thermogenesis, and protects against diet-induced obesity [38].

\subsection{Gut Microbiota and Protective Functions}

The human gut microbiota is involved in the construction of the mucus layer and the secretion of mucins in the intestine [39]; it also enhances the intestinal barrier, which protects against the colonization of pathogenic bacteria such as Streptococcus pneumoniae [40]. The bacteria of the microbiota influence the development of the immune system [41], as well as of the humoral and cellular immune system [42]. The gut microbiota releases metabolites that act as signals for the development of regulatory T-cells (Treg), T-helper type 1 and type 2 cells, and T-helper 17 cells [43]. In addition, the aforementioned SCFAs produced by gut bacteria influence the production of inflammatory mediators of macrophages; these are believed to be involved in a range of diseases, such as atherosclerosis and rheumatoid arthritis, as well as various neurodegenerative diseases [30]. Their course is influenced by the production and secretion of large amounts of TNF- $\alpha$, IL- $\beta$, IL- 6 , chemokines and nitric oxide by the activated macrophages, as well as various arachidonic acid derivatives, such as thromboxane $A_{2}$ and F1 $\alpha$. Butyrate decreases the release of TNF- $\alpha$, IL-6, IL-12 and IFN- $\gamma$, while increasing the release of anti-inflammatory IL-10 [44]. These SCFAs act as anti-inflammatory mediators, decreasing the release of macrophage chemoattractant protein (MCP), and increasing the release of IL-10 and prostaglandin E [45].

Germ-free (GF) animals, i.e., those devoid of microbes, typically exhibit immune deficiency. They are also characterized by a lack of $\mathrm{CD} 4^{+} \mathrm{T}$ cells, as well as defective $\mathrm{T}$ and $\mathrm{B}$ cell function, poorly developed lymphoid tissues, and decreased antibody production. In these animals, immune function may be restored by colonization of the GI. Alternatively, treatment with Bacteroides fragilis or its capsular antigen PSA (polysaccharide A) induces the proliferation of $\mathrm{CD} 4^{+} \mathrm{T}$ cells, and restores the development of lymphoid-containing spleen white pulp [46].

Lactobacilli regulate dendritic cell function, and influence the Th1/Th2/Th3 cytokine balance at the intestinal mucosa [47], as well as the activation of natural killer (NK) cells [48]. Gram-negative bacteria secrete peptidoglycan via NOD-like receptor (NOD1), which induces the formation of isolated lymphoid follicles (ILF) [49]. ILFs are organized lymphoid 
structures in the small intestine in humans and in mice. In mice, they contain a polyclonal population of B lymphocytes [50].

Certain strains of Clostridia (Cluster IV, XIVa, and XVIII) and Bacteroidetes also play a protective role in the body. These bacteria enhance the abundance of intestinal $\mathrm{CD} 4^{+} \mathrm{Foxp}^{+}$ regulatory $\mathrm{T}$ cells, which play several immunological functions, such as maintaining tolerance to commensal bacteria, suppressing the aggressive immune responses to autoand bacteria antigens, and inducing epithelial wound repair [51]. By releasing products that enhance neutrophil function, the human gut bacteria influence the development of the host innate immune system [52].

\subsection{Gut Microbiota and Neurotransmitters and Neuropeptides}

Several bacteria from the genera Lactobacillus, Bifidobacterium, Escherichia and Enterococcus synthesize and release neurotransmitters and neuropeptides. The main inhibitory neurotransmitter in the central nervous system (CNS) is gamma-aminobutyric acid (GABA), and disturbances in the GABA system can result in chronic disorders, such as anxiety and depression. GABA is produced from glutamate by various bacteria, such as Lactobacillus and Bifidobacterium [53]. Lacticaseibacillus rhamnosus can thus modulate the expression of GABA receptors in specific regions of the brain, and possibly play a role in the therapy of depression and anxiety [54]. Serotonin, a monoamine neurotransmitter, is also involved in the regulation of several brain functions and the modulation of various processes, including motor function, mood, sleep, pain, aggression, and sexual behavior [55]. Many neuropsychiatric disorders, including anxiety and depression, are associated with disturbances in the serotogenic system [56]. While approximately $90 \%$ of serotonin is synthesized and released by enterochromaffin cells, it can also be produced by bacteria from the genera Escherichia, Streptococcus and Enterococcus [57]. Gut microbiota can also enhance serotonin synthesis by activating SCFAs on enterochromaffin cells [58].

The human gut microbiota also produces other bioactive signaling molecules. Escherichia spp., Bacillus spp., and Serratia spp. produce dopamine, E. coli, Bacillus spp. and Saccharomyces spp. synthesize norepinephrine, while Lactobacillus spp. produce acetylcholine and glutamate $[59,60]$.

The CNS is a site of high expression of neurotrophin, a brain-derived neurotrophic factor (BDNF) which regulates multiple aspects of cognitive and emotional behavior [61]. This BDNF also influences neural survival and differentiation, and prevents neuronal damage and death, and decreased levels of BDNF have been observed in germ-free (GF) mice [62], and in the brains and serum of patients with Alzheimer's disease [63]. Pretreatment of animal models with a probiotic such as Bifidobacterium longum normalizes the BDNF levels [62].

\section{Modulators of Gut Microbiota Composition}

The composition of the gut microbiota depends on several factors, such as the method of delivery, diet while newborn and later in life, use of pharmaceuticals, probiotics and prebiotics, and intestinal microflora transplantation. These are also influenced by demographic factors such as age, sex, and ethnicity [64].

\subsection{Prenatal Factors}

Prenatal factors affect human gut microbiota. Microbes have been detected in the placenta [65], amniotic fluid [66], fetal membrane [67], umbilical cord blood [68], and meconium [69]. For example, bacteria belonging to the genera Enterococcus, Streptococcus, Staphylococcus, and Propionibacterium have been isolated from umbilical cord blood and from the meconium samples [68,70], and the DNA of Bifidobacterium and Lactobacillus has been isolated from placental samples [65]. Studies on Enterococcus faecium in animals suggest that gut microbiota may be translocated from mother to fetus via the bloodstream [70]; as such, it has been suggested that, in the case of Firmicutes, Tenericutes, Proteobacteria, Bacteroides, and Fusobacteria, maternal oral bacteria may be translocated to the fetus via the 
bloodstream [71,72]. Therefore, unlike previously believed, bacteria are translocated from mother to fetus in healthy pregnancies [70], and fetuses are not sterile.

\subsection{Method of Delivery}

In the case of vaginal delivery, newborns develop microbiota within 20 min of birth from the maternal vaginal or fecal microbiota. As such, the intestinal microbiota of newborns are similar to the vaginal microbiota of their mothers [73], with the most abundant bacteria in the gut microbiota of infants being Lactobacillus, Prevotella, and Sneathia [74]. In contrast, newborns delivered by Cesarean section typically present different gut microbiota, these being more characteristic of the microbiota of the skin from the hand that touches them after birth [75]; in these newborns, the most abundant bacteria are Staphylococcus, Corynebacterium, and Propionibacterium [74]. However, a few days after delivery, the composition of the gut microbiota shifts to being dominated by Proteobacteria and Actinobacteria [7].

\subsection{Method of Feeding}

The gut microbiota in breast-fed infants is dominated by Bifidobacterium [76] and Ruminococcus [77]. This microbiota presents significantly lower contributions of Escherichia coli, Clostridium difficile, Bacteroides fragilis, and Lactobacillus spp. than those of formula-fed bottle-fed infants [78]. In bottle-fed infants, the composition of gut microbiota includes enterobacterial genera, such as Streptococcus, Bacteroides, Clostridium, Bifidobacterium, and Atopobium [79]. The introduction of solid food results in the formation of a more complex and stable microbiota, similar to adult gut microbiota [80].

\subsection{Age}

As a child gets older, the intestinal microbiota gradually stabilizes. After one year of age, the composition of the gut microbiota resembles that of a young adult [73]. Later, at approximately 2.5 years of age, it becomes dominated by Firmicutes and Bacteroidetes [7], and finally resembles adult microbiota at around the age of seven [74]. At this age, about $90 \%$ of the bacterial composition comprises Firmicutes and Bacteroidetes, with the remaining $10 \%$ being made up of Terricutes, Cyanobacteria, and Proteobacteria [74]. In addition to the aging process, the composition of human gut microbiota may also be influenced by a range of factors, including pharmaceutical use, swallowing difficulties, and digestive problems. The low-grade systemic inflammation observed in the aging process stimulates the growth of pathobionts; as such, the microbiota of the elderly tend to demonstrate lower biodiversity [81]. The number of anaerobic bacteria remains stable, however, the proportion of facultative anaerobes increases. This gut microbiota is dominated by Bacteroides and Firmicutes, with Actinobacteria and Proteobacteria representing a smaller fraction [81]. Interestingly, gut microbiota composition in elderly people has been found to vary depending on nationality: while German, Austrian and Finnish seniors demonstrate an increased proportion of Bacteroidetes, Italian seniors do not indicate this [81].

\subsection{Diet}

One of the important factors influencing the composition of the gut microbiota is diet [82-84]. The modern diet consumed in industrialized countries tends to be rich in fat and saturated fatty acids, and higher in carbohydrates than that of preagricultural people [85,86]; this diet is accompanied by lower levels of dietary fiber and products with a low glycemic index [87]. European children tend to prefer this "Western diet", which is low in dietary fiber, but rich in animal protein and saturated fatty acids. Not surprisingly, compared to that of children in rural Africa, the gut microbiota of European children tends to be depleted in Bacteroides and bacteria from the genus Xylanibacter, but enriched in Enterobacteriaceae (Shigella and Escherichia), Firmicutes (Faecalibacterium and Acetitomaculum), and Gram-negative bacteria. The gut microbiota of the African children tends to contain a greater proportion of Bacteroidetes and Gram-positive bacteria, a higher 
ratio of Bacteroidetes:Firmicutes, and a greater abundance of Prevotella and Xylanibacter. The consumption of a Western diet also results in the loss of several bacterial species and a reduction in microbial diversity and stability [88], which are indicators of unhealthy microbiota [89]. The children from an African village in Burkina Faso were found to consume a low-fat but plant-rich diet [19]. The gut microbiota of the Hadza, a community of human hunter-gathers from Tanzania, was found to be characterized by much greater microbial richness and diversity than those of urban residents in Italy. The gut microbiota of the Hadza contained bacteria from the phylum Spirochaetes, the genera Anaerophaga, Sphingobacteriales, Ruminobacter and Treponema, and from family Veillonellaceae, whereas these taxa were absent from the Italian subjects; conversely, the microbiota of the Italian subjects over-expressed the phyla Actinobacteria and Firmicutes, as well as the genera Bifidobacterium, Bacteroides, Alistipes and Blautia, compared with the Hadza [88].

Other diets have also been found to influence the composition of human gut microbiota. A diet rich in plant-derived carbohydrates, digestible and non-digestible fiber, increases the proportions of Actinobacteria, Bacteroidetes (Prevotella, Xylanibacterium), Proteobacteria, Bifidobacteria, Lactobacilli, Ruminococcus, Eubacterium rectale, Blautia, Streptococcus, and Bifidobacteria. It also increases the diversity of the microbiota and Firmicutes:Bacteroides ratio, but decreases shares of Firmicutes, Bacteroides, Clostridium spp. Enterococcus, Roseburia, Bacteroidaceae, and Eubacterium. A vegetarian or vegan diet increases the proportion of Bacteroides thetaiotaomicron, Clostridium clostridioforme, Faecalibacterium prausnitzii, Bifidobacterium, and Lactobacillus, but decreases that of Acteroides spp., Enterobacteriaceae, Escherichia coli, Bacteroides fragilis, Clostridium perfringens, and Clostridium cluster XIVa. The Mediterranean diet, often regarded as the best diet, characterized by high amounts of fruits, grains, vegetables and monounsaturated fats, is associated with an increased share of Bacteroidetes, Clostridium, Prevotella and Firmicutes, and a lower share of Bacillaceae and Proteobacteria. Finally, a high-protein diet increases the shares of the Bacteroides enterotype, Alistipes, and Bilophila, and decreases that of Firmicutes, such as Ruminococcus bromii, Roseburia, and Eubacterium rectale [15,90-92].

\subsection{Probiotics}

Probiotics, treated as dietary supplements, are defined as "live microorganisms which when administered in adequate amounts, confer a health benefit on the host" [92]. Most bacterial probiotics currently sold are lactic acid bacteria Ligilactobacillus salivarius, Lacticaseibacillus paracasei, Limosilactobacillus reuteri, Lactiplantibacillus plantarum, and Lactobacillus gasseri) and Bifidobacterium, such as B. lactis [2]. Probiotics are involved in several human and animal functions, such as immune and metabolic processes, protection against diseases, and anti-tumorigenic effects [93]; they are also believed to influence the normalization of brain functions [59].

Animal studies indicate that probiotic use influences body weight. The administration of Limosilactobacillus ingluviei increases body weight [94], L. plantarum reduces adipocyte size in mice [95], and L. paracasei reduces fat accumulation [96]. Administration of Lacticaseibacillus casei/paracasei, L. plantarum, and L. gasseri demonstrated an anti-obesity effect [97]. Probiotic VSL\#3, which contains eight different strains of bacteria belonging to the genera Bifidobacterium and Lactobacillus, stimulates the secretion of GLP-1, a hunger-reducing hormone [98]. Probiotics have also been found to influence mood. B. longum and Lacticaseibacillus rhamnosus administration in animals normalizes anxiety-like behavior caused by the parasite Trichuris muris [54], and in humans, Lactobacillus and Bifidobacterium treatment has been found to decrease the symptoms of anxiety [99]. Two-week administration of Lactobacillus helveticus and B. longum also alleviated anxiety and depressive symptoms in healthy volunteers [100]. They are also believed to influence the human brain, especially regions that control processes associated with emotion and sensation [101]; they have been found to decrease the levels of BDNF and modulate the levels of GABA [54], as well as a range of other functions [15]. It was found that probiotic treatment decreases the levels of C-reactive protein, total cholesterol, LDL-cholesterol, and plasma triglycerides, 
and increases those of SCFAs, IL-10, IGA, HDL-cholesterol; administration has also been associated with insulin sensitivity [102-104]. Administration of probiotics increases the counts of beneficial gut bacteria, such as Bifidobacteria and Lactobacilli, and significantly reduces those of enteropathogens, such as E. coli and H. pylori $[105,106]$.

\subsection{Prebiotics}

A prebiotic is "a nondigestible food ingredient that beneficially affects the host by selectively stimulating the growth and activity of one or a limited number of bacteria in the colon, and thus improving host health" [107]. Prebiotics are not hydrolyzed by the enzymes of the human intestine, but are selectively fermented by colonic bacteria. Several compounds may serve as prebiotics, such as inulin, oligosaccharides, and dietary polyphenols. Inulin is the general term used to describe $\beta(2-1)$ linear fructans with variable degrees of polymerization. Colonic bacteria ferment inulin to SCFAs and gases. Various oligosaccharides, such as fructooligosaccharides (FOSs), galactooligosaccharides (GOSs), soybean oligosaccharides (SBOSs) may act as probiotics [108], and vegetables such as Jerusalem artichokes and chicory, which contain inulin, are regarded as prebiotic-rich foods. Inulin increases the counts of beneficial bacteria, such as Bifidobacteria and Lactobacilli [109,110], and decreases the counts of enterococci [111], facultative anaerobes [112], and Bacteroides [109]. In obese women, inulin was found to increase the count of Bifidobacterium and Faecalibacterium prausnitzii, and decrease those of Bacteroides and Propionibacterium [113]. Uptake of Yacon syrup, which contains FOS or GOS, was found to decrease the body weight, BMI, and waist circumference in obese adults, as well as serum LDL-cholesterol and glucose levels [114]. Several investigations have found prebiotics to have a beneficial role in human metabolic disorders [15].

Prebiotics have also been found to influence brain functions. Arabinoxylan, a plant polysaccharide, stimulates the growth of beneficial bacteria known to produce butyrate, such as Roseburia intestinalis, Eubacterium rectale and Anaerostipes caccae [115]. It has also been proposed that plant polyphenols may also have prebiotic properties; these compounds are plentiful in fruits, nuts, seeds, and vegetables, as well as food products and beverages such as chocolate, coffee, red wine, and soymilk. Polyphenols increase the counts of Bifidobacteria and Lactobacilli, and decrease those of Bacteroides, Clostridium, Salmonella typhimurium and Staphylococcus aureus [116].

\subsection{Pharmaceutical Use}

Recent years have seen an increase in antibiotic therapy. Antibiotics significantly influence the composition of human gut microbiota, with some taxa not recovering for several months after treatment [117]: while the human intestinal microbiota can take four weeks to recover from five-day antibiotic treatment, some taxa may need six months to return to levels before therapy. Antibiotic therapy mainly reduces the diversity and/or abundance of Bacteroides, and decreases the evenness of the community [118]. Treatment with ampicillin and gentamycin within $48 \mathrm{~h}$ of birth in a mother has been associated with higher counts of Proteobacteria in the infant gut microbiota, and lower counts of Actinobacteria and the genus Lactobacillus, compared to those of untreated mothers. After eight weeks, the recovery was still incomplete, and the level of Proteobacteria remained elevated [119]. Several other antibiotics have been found to influence the infant gut microbiota. For example, administration of cephalexin reduces the levels of Bifidobacterium and increases those of Enterococcus and Enterobacteriaceae [120], and six-week intravenous treatment with vancomycin was found to change the level of Lactobacillus [121]. The use of antibiotic therapy in newborns may cause the overgrowth of Clostridium difficile, resulting in antibiotic-associated diarrhea [122]. Several of these observations have been confirmed in animal studies [123]. Interestingly, the use of antibiotics in animals has been found to increase the gastrointestinal abundance of Candida albicans [124].

Metformin, widely used in patients with type 2 diabetes mellitus, also influences the human gut microbiota. The levels of metformin in serum correlate positively with 
Escherichia counts, and negatively with Intestinibacter $[125,126]$. It has also been suggested that metformin may have beneficial effects by increasing the levels of butyrate and propionate producers [126].

\subsection{Intestinal Microflora Transplantation}

Intestinal microflora transplantation (IMT) [2], also known as fecal microbial transplantation (FMT) [127], was used more than a hundred years ago as a traditional Chinese medicine to treat diarrhea [128]. The technique has also been used in contemporary medicine, in patients presenting pseudomembranous colitis after antibiotic treatment of Clostridium difficile. Since then, IMT has been extended to treat other diseases, including those of the GI tract [7]. The aim is restoring normal intestinal microbial balance [129]. Fecal microbiota obtained from the filtrate stool of a "healthy" donor is transplanted to a recipient with a disturbed or altered microbiota. The method of introduction of microbiota depends on the disease. The sample is introduced by endoscopy into the large intestine in the case of Clostridium difficile infection, and into the duodenum in the case of metabolic syndrome [2]. This technique has frequently been used to treated Clostridium difficile infection, and has been found to be highly effective. These patients demonstrate decreased levels of Bacteroidetes and Firmicutes; however, 14 days after transplantation, the microbiota was dominated by Bacteroides spp. [130]. IMT has also been proposed as a treatment for inflammatory bowel disease [131], metabolic syndrome [132], type 2 diabetes mellitus [133], autism spectrum disorder and mood disorders [134], as well as Parkinson's disease [135], Alzheimer's disease, and several others [136,137]. Various next-generation therapies have also been proposed in which synthetic microbial composition in place of the microbial composition of healthy donors is used [138]. However, FMT is generally not well accepted by patients.

\section{Metabolic Endotoxemia}

Metabolic endotoxemia, first described in mice, is the term given to increased levels of lipopolisaccharides (LPS) in blood plasma [139]. LPS is a cell wall component derived from the lysis of Gram-negative bacteria in the intestine. After an absorption by enterocytes, LPS is carried in plasma and bound to chylomicrons [140]. In humans, the overgrowth of Gram-negative bacteria is closely associated with the consumption of a high-fat diet.

Toll-like receptors (TLRs) play a crucial role in the innate immune system, and the combination of LPS with CD14 can act as a ligand for TLR-4. LPS binds to the CD14/TLR-4 receptor in macrophages, triggering an inflammatory cascade [139]. In healthy humans, metabolic endotoxemia increases the levels of adipose TNF- $\alpha$ and IL-6, thus promoting insulin resistance [141]. The postprandial increase of plasma LPS observed after a high-fat meal increases the expression of NF- $\mathrm{kB}$ and a suppressor of cytokine signaling-3 (SOCS-3), which are involved in insulin resistance; no such changes are observed in the case of a diet rich in fiber and fruits [142]. Increased levels of plasma LPS stimulate the CD14/TLR-4 complex, which stimulates the TLR-2 mediated inflammatory response, thus increasing the secretion of pro-inflammatory cytokines by adipose tissue [143]. Animal studies based on mice have found that a high-fat diet changes the composition of gut microbiota; more specifically, a reduction in the abundance of Bifidobacteria spp. and Eubacteria spp. accompanied by a 2- to 3-fold increase in LPS level [144].

\section{Dysbiosis}

The term dysbiosis is defined as an "increase in the population of gut bacteria with pathogenic traits, which occasionally causes diseases" [145]. Hence, dysbiosis results in a change in the composition of the gut microbiota, characterized by a decrease in the share of symbionts and commensals, and/or an increase in the share of pathobionts. As mentioned earlier, several factors may change the balance and induce dysbiosis, which may directly or indirectly influence the course of several diseases [146-150]. In addition, fungal dysbiosis may also play a role in several diseases $[14,151]$. 


\section{Human Microbiota Dysbiosis and Cancers}

Carcinogenesis progresses through three stages: initiation, progression, and metastasis. The tumor requires a particular environment, known as the tumor microenvironment (TME), to grow and thrive. The TME promotes tumor transformation, growth and invasion, protects it from host immunity, and enhances resistance to therapeutics [152,153].

The development of cancer may be caused by several factors. Certain bacteria, viruses, and fungi may influence cellular dysplasia and carcinogenesis, while inflammation can also promote tumorigenesis and proliferation [154]. In most cases, carcinogenesis occurs secondary to the creation of a local chronic inflammation state. Some bacteria, such as Helicobacter pylori, may directly contribute to the process of tumorigenesis by influencing the intracellular signaling pathways involved in the regulation of cell growth and proliferation [155]. Examples of such oncogenic bacteria include Salmonella typhi and Helicobacter spp. in biliary cancer [156], and H. pylori in gastric cancer [155]. In addition, viruses such as hepatitis $\mathrm{C}$ virus (HCV) and hepatitis $B$ virus (HBV) are known to support the development of hepatocellular carcinoma [157]. Approximately $16 \%$ of human cancers are caused by infectious factors or infection-associated chronic inflammation [158].

The process of tumorigenesis may involve various mechanisms. Some bacterial species, such as Bacteroides fragilis, stimulate inflammation, and the induction of pro-inflammatory toxins may promote carcinogenesis [159]; Helicobacter hepaticus stimulates the development of colon cancer in animal models, increasing the production of reactive oxygen species [160]; Fusobacterium nucleatum may alter signaling pathways and inhibit host antitumor immune function [161]; Escherichia coli produces genotoxic metabolites, such as colibactin, and Campylobacter jejuni produces a cytolethal toxin, known to induce carcinogenesis in animal models [162]. Fusobacterium nucleatum produces a FadA adhesion complex (FadAc), which activates the $\beta$-catenin-Wnt signaling pathway, influencing oncogene transcription in human colon cancer cell lines [163]. F. nucleatum has also been found to influence the development and progression of colon adenomas and colon cancers [164,165], and other bacterial species are believed to employ other mechanisms [166-168].

\subsection{Human Gut Microbiota and Cancers of Digestive System}

Several cancers of the digestive system are caused by the dysbiosis of gut microbiota. These bacteria are known to be involved in the initiation, progression, and metastasis of cancers in various organs of the human digestive system.

\subsubsection{Oral Cavity Cancers}

Oral cavity cancer, primarily oral squamous cell carcinoma (OSCC), arises from oral mucosa. It is the fourteenth most prevalent malignancy worldwide [169]. Approximately $90 \%$ of oral cavity cancers are squamous cell carcinoma.

The healthy oral cavity is home to 772 bacterial species, belonging to 185 genera and 12 phyla. The most abundant phyla, constituting $96 \%$ of oral bacteria, are the Firmicutes, Actinobacteria, Fusobacteria, Bacteroides and Spirochaetes. Lower levels of Chloroflexi, Chlamydiae, Saccharibacteria and Gracilibacteria are also observed $[170,171]$. In a healthy oral cavity, the predominant bacteria include 12 Gram-positive genera, including Abiotrophia, Peptostreptococcus, Actinomyces, Bifidobacterium and Lactobacillus and 15 Gram-negative genera, including Neisseria, Veillonella, Capnocytophaga, Fusobacterium and Prevotella [172]. Other nonbacterial organisms have also been recorded, including the protozoa Entamoeba gingivalis and Trichomonas tenax, and 85 fungal genera, such as Candida, Aureobasidium, Saccharomycetales, Aspergillus, Fusarium, and Cryptococcus [173]. Taxonomic diversity within samples is known as $\alpha$-diversity, and diversity between samples as $\beta$-diversity [174].

Several environmental factors, including changes in the composition of microbiota, may be involved in the development of oral squamous cell carcinoma (OSCC). Several authors have suggested potential associations between oral dysbiosis and oral cancer [175]. In patients with OSCC from Sri Lanka, cancer tissue samples demonstrated lower species 
richness and diversity, characterized by the overexpression of certain genera, such as Capnocytophaga, Pseudomonas and Atopobium, and species such as Campylobacter concisus, Prevotella salivae, P. loeschii, and Fusobacterium oral taxon 204, as compared to control patients with fibroepithelial polyps. The OSCC tissue demonstrated a predominance of proinflammatory bacterial attributes, such as the biosynthesis of LPS and peptides [176]. Of note, the increased expression of genes involved in bacterial chemotaxis, flagellar assembly and biosynthesis is also associated with pathological processes [177]. Another investigation revealed drastic changes in the composition of oral microbiota in patients with OSCC. The cancer samples demonstrated significantly higher bacterial diversity than healthy controls, with the cancer samples demonstrating significantly higher levels of Fusobacterium, Peptostreptococcus, Dialister, Filifactor, Peptococcus, Catonella, and Parvimonas. Significantly higher diversity and richness in tumor sites have also been noted in other investigations of OSCC [177]. Cancer tissues were found to be significantly enriched in six families: Prevotellaceae, Fusobacteriaceae, Flavobacteriaceae, Lachnospiraceae, Peptostreptococcaceae and Campylobacteriaceae, and 13 genera, including Fusobacterium, Allomevotella and Porphyromonas. At the species level, Fusobacterium nucleatum, Prevotella intermedia, Aggregatibacter seqnis, Capnocytophaga leadbetteri, Peptostreptococcus stomatis, among others, were all found to be significantly increased in patients with OSCC [177]. Other studies have noted an association between dysbiosis in the oral microbiota and the development of OSCC [178-180]. It has been proposed that some oral taxa, especially Porphyromonas gingivalis and Fusobacterium nucleatum, may have carcinogenic potential [181,182], and some aerobic bacteria, such as Parvimonas, could also be linked to tumorigenesis [183]. It has also been suggested that oral and gut microbiota may serve as potential biomarkers in cancer [184,185], with three oral bacterial species being good candidates as diagnostic indicators of OSCC: Capnocytophaga gingivalis, Prevotella melaninogenica, and Streptococcus mitis [179]; Peptostreptococcus spp. and Porphyromonas gingivalis have also been proposed [186]. Interestingly, Salmonella typhimurium and Clostridium spp. may be used for targeted strategies as a potential vectors to treat cancer [182].

Gingival carcinoma is the third most prevalent oral cancer, with less than $10 \%$ morbidity. Higher levels of LPS biosynthesis were observed in the subgingival plaque of gingival squamous cell carcinoma (GSCC). The authors suggest that high levels of Atopobium in saliva and LPS synthesis have the potential risk of suffering in individuals with periodontitis [187].

Three mechanisms have been proposed for the influence of oral microbiota on the development of cancer [188]. The first involved stimulation of chronic inflammation by bacteria such as Porphyromonas gingivalis, Fusobacterium nucleatum, Streptococcus anginosus, and Prevotella spp. [186,189]. Oral epithelial cells produce pro-inflammatory cytokines and chemokines, including IL-1 $\beta$, IL-6, IL-8, IL-23, TNF- $\alpha$, and metalloproteinases, such as matrix metalloproteinase-8 (MMP-8) and MMP-9 [190]; these inflammatory mediators may induce or facilitate cell proliferation, mutagenesis, oncogene activation and angiogenesis [191]. The resulting chronic inflammation may cause immunosuppression, influencing the development of OSCC [192]. Alternatively, oral bacteria may affect cell proliferation, cytoskeletal rearrangement and NF-кB activation, and inhibit apoptosis. Porphyromonas gingivalis increases the level of cyclin A, diminishes the level and activity of p53, and activates the PI3-K pathway, inducing the proliferation of gingival epithelial cells [193]. Interestingly, the PI3-K/AKT and JAK/Stat3 signaling pathways are known to inhibit gingival epithelial cell apoptosis [194]. P. gingivalis may also cause immunosuppression [189]. Finally, bacteria such as Porphyromonas gingivalis, Prevotella intermedia, Aggregatibacter actinomycetemcomitans, and Fusobacterium nucleatum are known to produce various substances that may have carcinogenic properties, such as reactive oxygen species, reactive nitrogen species, organic acids, and various volatile sulfur compounds (VSC) such as hydrogen sulfide, methyl mercaptan and dimethyl sulfide $[186,188]$. Other oral microbiota, such as Neisseria sp. and Candida sp., produce acetylaldehyde and N-nitrosamine compounds, which may also be carcinogenic [195]. Colonization with fungal species also may be a risk 
factor in OSCC. Patients with OSCC demonstrated significantly higher levels of Candida albicans than healthy controls [196], and the C. albicans isolated from patients with OSCC were found to be genotypically different from those isolated from healthy subjects [197]. It has been suggested that $C$. albicans isolated from cancer tissue may demonstrate greater acetylaldehyde production and nitrosylating activity [198]. C. albicans was found to induce neoplastic mucosal changes in an animal model of chemically induced carcinogenesis [199]. Other studies have indicated an increased abundance of fungal species, such as Candida etchellsii and Hanaella luteola, in patients with OSCC [195]. One particularly interesting observation is that Candida colonization appears to be associated with increased levels of $F$. nucleatum [200].

\subsubsection{Esophageal Cancer}

Esophageal cancer (EC) is the eighth most common cancer worldwide, and the sixth most common cause of cancer-related death [201]. There are two major histological types of esophageal cancers: esophageal adenocarcinoma (EAC) and esophageal squamous cell carcinoma (ESCC) [202]. EAC localizes in the distal esophagus, whereas ESCC localizes in the middle thoracic esophagus. In developed countries, the most common type is EAC, whereas ESCC predominates in developing countries [203]. EAC develops from the precursor lesion Barrett's esophagus (BE), a characteristic metaplastic change of the mucosa of the distal esophagus [204]. Only 1 in 860 patients with BE will develop EAC [205]; however, more than $85 \%$ of patients with newly diagnosed EAC have no history of BE [206].

Healthy esophagus tissue has been found to include bacteria from 97 species belonging to six phyla: Firmicutes, Bacteroides, Actinobacteria, Proteobacteria, Fusobacteria, and TM7. Of these, the most common genera are Streptococcus (39\%), Prevotella (17\%), and Veillonella $(14 \%)[207,208]$. No difference in microbiota was found between benign and malignant tissues in surgically resected samples from patients with EAC and ESCC; in addition, the same bacteria were detected in normal and cancerous tissues [209]. More recent studies revealed a higher abundance of Treponema denticola, Streptococcus mitis, and S. anginosus in EAC samples compared to healthy controls; however, the pathological subtypes of the tumors were not specified [210]. Tissue samples from patients with EAC demonstrated decreased diversity [211], decreased levels of Veillonella and Granulicatella, and increased levels of Limosilactobacillus fermentum. It has been suggested that the presence of the genus Neisseria and the species L. fermentum may be associated with the risk of EAC [212]. In addition, chronic infection with Helicobacter pylori also appears to be inversely related to the risk of EAC [206,213]; however, the mechanism by which $H$. pylori affects carcinogenesis in the lower esophagus remains unclear [213]. There is also a need to better clarify the associations between the microbiome and EAC [214].

Little evidence exists regarding the microbiome in patients with ESCC [214]. Patients with esophageal dysplasia, a precursor of ESCC, demonstrated significantly lower numbers of microbial genera in the upper gastrointestinal tract, as well as the presence of Porphyromonas gingivalis, which was not observed in healthy control subjects [215]. Positive correlations have also been noted between the presence of $P$. gingivlis and cancer cell differentiation, metastasis, and poor clinical outcome [216]. Changes in the composition of bacterial microbiota in the saliva is associated with a higher risk of ESCC; patients with ESCC demonstrated a decreased abundance of the genera Lautropia, Bulleidia, Catonella, Corynebacterium, Moryella, Peptococcus, and Cardiobacterium as compared to healthy controls [217]. It has also been noted that patients with ESCC displayed a higher proportion of Firmicutes, lower share of Gammaproteobacteria, and higher proportion of Bacilli than in healthy controls. In these patients, $\alpha$-diversity and richness were significantly lower than in healthy subjects, whereas $\beta$-diversity was higher [202]. It has also been suggested that a key role in the development of ESCC may be played by Fusobacterium nucleatum, a species that primarily inhabits the oral cavity, and has been detected in colon cancer tissue. This bacterium was detected in cancer tissue in about $23 \%$ of patients who underwent 
surgical resection of esophageal cancer. Its presence in cancer tissue is also associated with significantly shorter survival time [218].

\subsubsection{Gastric Cancer}

Gastric cancer (GC) is the fifth most common cancer in the world, and the third leading cause of cancer-associated death worldwide [201]. Although GC is associated with various etiologies, Helicobacter pylori infection is the most well-established risk factor for its development [219]. Although H. pylori is known to induce chronic gastritis, and is associated with more than $90 \%$ of GC cases [220], GC is only observed in 1-3\% of patients infected with $H$. pylori $[221,222]$. Nevertheless, $H$. pylori has been recognized by the WHO as a "definite carcinogen" [220]. The carcinogenesis of GC may involve other factors. The composition of gastric microbiome depends on gastric acidity [223], and due to its acidic environment, only $H$. pylori is able to colonize the human stomach. Such colonization causes chronic inflammation, which is believed to be the first step to GC. In the case of antral-predominant gastritis, bacteria stimulate the secretion of gastrin; although this causes further production of gastric acid and increases the risk of duodenal ulcers, it also protects patients against GC. In the case of corps-predominant gastritis, H. pylori suppresses the production of gastric acid through inflammatory mediators. This disturbance may cause the progressive loss of gastric glands, and leads to atrophic gastritis [224]. Corps-predominant gastritis may influence the development of carcinogenesis. Changes of gastric $\mathrm{pH}$, due to reduced secretion of gastric acid, allow colonization by bacteria other than $H$. pylori from the oral cavity, upper respiratory tract, or the intestine; these bacteria are not normally detected in a normal stomach, because they cannot survive the hostile gastric environment. Changes of gastric $\mathrm{pH}$ may also be associated with the increased abundance of nitrosating species of bacteria in the stomach, as well as elevated nitride and N-nitrosamine levels [225].

A comparison of the gastric mucosal microbiota between $H$. pylori-negative and $H$. pylori-positive patients indicated that the H. pylori-positive gastritis patients demonstrated significantly lower bacterial richness. The H. pylori-negative patients also demonstrated increased levels of bacteria from the phyla Firmicutes, Fusobacteria, Bacteroidetes, and Actinobacteria; they also demonstrated higher counts of Streptococcus spp. and Haemophilus influenzae and, unlike the positive patients, they were found to display Treponema spp. The authors suggest that Streptococcus spp., Haemophilus parainfluenzae, and Treponema spp. may be potential pathogenic bacteria for the $H$. pylori-negative gastritis group. In addition, the relative abundance of $H$. pylori was found to be around $90 \%$ ( $\alpha$-diversity) in the $H$. pylori-positive group, while greater $\beta$-diversity was observed among $H$. pylori-negative patients [226]. Patients after gastrectomy for gastric cancer were also found to have higher species diversity and richness than healthy controls, with a higher abundance of aerobes, facultative anaerobes, and oral microbiota. Significantly higher levels of Bifidobacterium nucleatum were also observed, a species known to be related to colorectal cancer [227]. In addition, higher diversity and richness have been observed in cancerous tissue in comparison with non-cancer tissue [228]; the cancer samples were dominated by oral bacteria, such as Peptostreptococcus, Streptococcus, and Fusobacterium, and the non-cancerous controls by lactic acid-producing bacteria such as Lactobacillus lactis and Levilactobacillus brevis. In the cancerous samples, the predominant phylum was Proteobacteria, overall being found in 90\% of cancerous samples, followed by Firmicutes, Bacteroidetes, Actinobacteria, and Fusobacteria. The non-tumor samples demonstrated higher levels of Proteobacteria than the cancerous samples, and lower levels of Firmicutes, Actinobacteria, and Fusobacteria [228].

Bacteria that can produce N-nitroso compounds, such as E. coli, Lactobacillus, Nitrospirae, Clostridium, Veillonella, Haemophilus, and Staphylococcus, have also been associated with GC [229]. In addition, Streptococcus, Prevotella, and Neisseria are treated as low risk factors for the development of GC, and it has been proposed that H. pylori changes the composition of the gastric microbiota, facilitating the colonization of stomach by oral bacteria [230]. This dysbiosis may influence the maintenance of the local microenvironment, stimulating the development and/or progression of GC [231-234]; however, the role of the gastric 
microbiome in the development of gastric cancer remains unclear [235]. Nevertheless, it has been suggested that $H$. pylori eradication therapy may be an effective way to prevent gastric cancer.

\subsubsection{Colorectal Cancer}

Colorectal cancer (CRC) is one of the most commonly diagnosed malignances, and the third most prevalent cancer worldwide [163]. Its development has been closely associated with diet, suggesting that the gut microbiota may play a role in the development and progression of CRC [236]. A reasonable body of evidence exists to support this theory [237]. Higher levels of bacteria belonging to the group Bacteroides-Prevotella have been noted in stool samples of patients with CRC compared to healthy controls, and increased levels of Enterococcus, Escherichia, Shigella, Klebsiella, Streptococcus, and Peptostreptococcus were recorded in the luminal compartment of these patients [238]. These patients also demonstrated lower levels of butyrate producing bacteria belonging to the family Lachnospiraceae, as reported previously [239]. Several other studies have also reported higher proportions of Fusobacterium, Parvimonas, Butyrivibrio, Gemella, Fusobacteria, and Akkermansia in patients with CRC, and lower levels of Ruminococcus, Bifidobacterium, Eubacteria, and Lachnospira compared to healthy subjects [240-242].

The microbiome of CRC patients is often enriched in pro-inflammatory opportunistic pathogens and bacteria that influence the development of metabolic diseases, such as Streptococcus bovis, Fusobacterium nucleatum, Escherichia coli, Bacteroides fragilis, and Enterococcus faecalis, and lower levels of butyrate-producing bacteria, such as those of the Roseburia, Clostridium, Faecalibacterium, and Bifidobacterium genera [243-245]. High levels of Bacteroides increase the risk of colon polyps, whereas Lactobacillus and Eubacterium play a protective role [246]. In addition, higher levels of bacteria producing hydrogen sulfide and bile salts are also indicators of an increased risk of CRC development [247].

The stage of carcinogenesis has also been found to be associated with the composition of gut microbiota. In patients with adenoma, the intestinal mucosal surface demonstrated an increased amount of Firmicutes, Bacteroidetes, and Prevotella, in comparison with healthy controls [248]. However, resected tissues from patients with adenocarcinoma displayed higher levels of bacteria belonging to the phylum Bacteroides and lower levels of Firmicutes; in addition, an overabundance of Fusobacterium was found in samples of tumor as compared to healthy controls [249].

Several explanations have been proposed for the role of microbial dysbiosis in the development of CRC. It has been suggested, for example, that microbiota may have an epigenetic influence on host DNA expression, and that gut microbiota dysbiosis may promote carcinogenesis via epigenetic dysregulation based on gene methylation [237]. Animal studies revealed that germ-free mice that receive feces from patients with CRC showed higher numbers of hypermethylated genes in the colonic mucosa compared to those that receive feces from healthy controls. These mice also demonstrated a higher rate of colon epithelial renewal, and more precancerous lesions [237].

Alternatively, CRC patients have been found to demonstrate increased levels of Fusobacterium nucleatum. An F. nucleatum surface protein, FadA, binds to E-cadherin on epithelial cells, activates oncogenic pro-proliferative $\beta$-cadherin signaling [250], and stimulates the production of inflammatory cytokines such as IL-6, IL-8, and IL-18 [251]. This bacterium may also alter the function of tumor-infiltrating lymphocytes (TIL) and natural killer (NK) cells. It binds to the inhibitory immune receptor TIGIT (T cell immunoreceptor with Ig and ITIM domains), through another adhesion molecule, Fap 2 [161]. TIGIT is found as a protein on NK cells, and its activation enhances tumor killing [252], and the binding of bacteria to TIGIT blocks the anti-tumor activity of NK cells [161]. F. nucleatum can also activate the NF-kB pathway, thus inducing the expression of genes encoding pro-inflammatory cytokines [250,251]. An elevated level of NF-kB transcripts, observed in tumor tissue, decreases the levels of CD3-positive T-cells, suggesting that F. nucleatum obstructs the antitumor immune mechanism in cancer patients [253]. Indeed, in patients 
with stage III/IV of cancer, higher levels of $F$. nucleatum have been observed in tumor tissues than healthy tissues. A positive correlation has also been found between the levels of $F$. nucleatum and tumor invasion, and lymph node and distal metastasis [254].

Bacteroides fragilis, an enterotoxigenic bacteria (ETBF) which causes diarrhea and inflammation of the gastrointestinal tract, is also involved in colorectal carcinogenesis. Its presence is observed in biofilms coating human colorectal cancers and adenomas [255]. The $B$. fragilis-derived toxin (BFT) produced by these bacteria activates spermine oxidase produced by the host; its activation generates hydrogen peroxide and reactive oxygen species that damage the DNA in epithelial cells, promoting tumorigenesis [256]. The produced toxin also interacts with epithelial E-cadherin, disrupting the intracellular junction and activating $\beta$-catenin nuclear signaling, which induces cell proliferation [257]. These bacteria may induce the production of inflammatory cytokine IL-17, thus decreasing host anti-cancer immune responses and allowing cancer growth [258].

Higher levels of Escherichia coli have been observed in patients with CRC in comparison to healthy subjects [244]. This enterogenic bacterium expresses the genomic island polyketide synthase $\left(\mathrm{pks}^{+}\right)$, which has been found to enhance tumorigenesis in preclinical models of CRC. E. coli $\mathrm{pks}^{+}$produces the genotoxin colibactin [259] which alkylates DNA, causing double-strand breaks in DNA mammalian cells [260]. Colibactin also triggers premature and transmissible cellular senescence in the cells that initially survive DNA damage [261]. The influence of E. coli on the development of CRC was also confirmed in animal studies [259].

\subsubsection{Pancreatic Ductal Adenocarcinoma}

Pancreatic ductal adenocarcinoma (PDAC) is a lethal and highly aggressive malignancy $[262,263]$. Growing evidence suggests that gut microbiota may play a role in PDAC susceptibility, initiation, and progression [264,265], as noted in animal studies [266]. The pancreas is generally considered to be free of microbes due to the presence of numerous proteases and a highly alkaline environment [267]; however, previous studies indicate increased bacterial abundance in cancerous pancreas tissues [268]. For example, patients with PDAC demonstrated 1000-fold greater levels of intrapancreatic bacteria in comparison with healthy pancreatic tissue [269]; the presence of Fusobacterium sp. in pancreatic tissues is correlated with poor pancreatic cancer prognosis [270], and the presence of Gammaproteobacteria in PDAC tissue inhibits the therapeutic effects of the anticancer drug, gemcitabine; it is believed that it is metabolized by the bacteria [271].

H. pylori is also believed to play a role in the initiation of pancreatic carcinogenesis [272]. Several subspecies of Helicobacter have been identified in the pancreas [273], and they have been found to produce a range of bacterial pathogenic compounds, such as ammonia, LPS, and inflammatory cytokines, which may damage the pancreas [274]. H. pylori can also dysregulate cellular processes by activating NF- $\mathrm{kB}$ and activator protein-1 (AP-1) and inducing mutations in K-Ras: these were observed in over $90 \%$ of investigated tissue samples [275]. The mutated cells are hyperstimulated by LPS, initiating the process of pancreatic carcinogenesis [276]. Infection of $H$. pylori also causes the activation of signal transducer and activator of transcription 3 (STAT3), resulting in the overexpression of anti-apoptotic and pro-proliferative proteins such as Bcl-xL, MCL-1, c-myc, and cyclin D1, which may promote cancer progression [277].

The risk of PDAC may also be increased by the dysbiosis of oral microbiota associated with periodontal disease and tooth loss [273,278]. It is suggested that the presence of such dysbiosis promotes the development of pancreatic cancer, rather than the other way round. For example, blood samples of patients with PDAC demonstrated significantly higher levels of antibodies against Porphyromonas gingivalis. This bacterium is a known periodontal pathogen which causes chronic periodontitis, and its greater abundance is associated with a twofold greater risk of cancer development [279]. In addition, the presence of $P$. gingivalis and Aggregatibacter actinomycetemitans in the oral cavity is believed to increase the risk of PDAC, whereas that of Fucobacteria and Leptotricha decreases it [280]. The main oral 
bacteria involved in the development of PDAC are P. gingivalis, Fusobacterium, Neisseria elongata, and Streptococcus mitis [273].

In addition, $P$. gingivalis, Treponema denticola, and Tannerella forsythia, known as "the red complex", may also play a role in PDAC carcinogenesis. They are believed to be the key pathogens causing periodontitis. These bacteria secrete peptidyl-arginine deiminase (PAD) enzymes, which may cause point mutations in $p 53$ (tumor suppressor gene), and the oncogene K-Ras [281], the presence of which indicates a poor prognosis for patients with PDAC [282].

Fusobacterium spp. are also known to cause periodontal disease [283]. As this bacterium increases the production of reactive oxygen species and inflammatory cytokines and modulates the tumor microenvironment, it may be involved in the process of tumorigenesis [284]; in addition, the presence of Fusobacterium has been associated with a reduced risk of PDAC development $[279,280]$. Several other associations have also been found between oral microbiota and PDAC $[285,286]$, which have also been confirmed in animal studies [266].

It has also been found that cancer patients with long-term survival (median survival 10.1 years) demonstrated higher $\alpha$-diversity in the composition of tumor microbiome following surgical resection than those with short-term survival (median survival 1.6 years). The authors propose that $\alpha$-diversity may be treated as a predictor of survival in patients with PDAC after surgical resection [286]. In addition, the patients with long-term survival demonstrated significantly higher levels of Pseudoxanthoma, Saccharopolyspora, and Streptomyces than those with short-term survival, suggesting that these three genera, and additional Bacillus clausii may predict long-term survival in PDAC patients [286].

The most common pancreatic cystic neoplasms (PCNs) are intraductal papillary mucinous neoplasms (IPMNs) [287]. These pancreatic cysts are characterized by malignant transformation to invasive carcinoma [288], from PCN, through low-grade dysplasia (LGD), high-grade dysplasia (HGD), to invasive carcinoma [287]. IPMN may be treated as an early indicator of pancreatic cancer [278]. Higher levels of Fusobacterium nucleatum and Granulicatella adiacens were found in samples obtained from patients with IPMNs compared to healthy controls, and higher levels of Granulicatella, Serratia, and Fusobacterium were observed in samples of HGD; lower levels of Methylbacterium, Sphingomonas, and Propionibacterium were also observed in the two groups [278]. Of note, these bacteria are oral microbiota.

\subsubsection{Hepatocellular Carcinoma and Cholangiocarcinoma}

Although hepatocellular carcinoma (HCC) is the most common histological type of liver cancer [289], little research has been performed on the associations between gut microbiota and HCC in humans. Despite this, investigations of fecal samples of patients with HCC revealed higher levels of Escherichia coli in comparison with healthy controls [290,291], as well as decreased levels of Bifidobacterium and increased levels of Bacteroides and Ruminococcus [292]. A Chinese population of patients with early HCC demonstrated higher levels of the phylum Actinobacteria and 13 genera, including Gemmiger, Parabacteroides, Prevotella, Alistipes, Phascolarctobacterium and Ruminococcus, and lower levels of Verrucomicroba, Klebsiella and Haemophilus in comparison with healthy controls. Hence, patients with HCC demonstrated lower levels of butyrate-producing bacteria and higher levels of LPS-producing genera; they also displayed greater gut microbial diversity [293].

Helicobacter spp. has also been implicated in the development of HCC. It has been detected in the liver of patients with primary hepatic carcinoma, but not in healthy controls [294]; in addition, H. hepaticus was not detected in HCC patients with chronic hepatitis B or C [295]. H. pylori, H. bilis, H. hepaticus, and H. ganmani are specifically associated with cholangiocarcinoma, but not non-tumor diseases in the bile duct [296]. Salmonella typhi has also been associated with gallbladder and hepatobiliary carcinoma. HCC patients have also demonstrated changes in the composition of the tongue coating, and it has been suggested that the enrichment of tongue Oribacterium and Fusobacterium may be treated as 
a biomarker of HCC [297]. Further associations between the dysbiosis of gut microbiota and development of HCC have been described by other researchers $[150,289,298-300]$.

Human gut microbiota may produce LPS, which can activate Toll-like receptor 4 (TLR4), causing the development of liver cancer [301]. Animal studies have found that lipopolysaccharide influences hepatic Kupffer cells, which produce the inflammatory cytokines TNF- $\alpha$ and IL-6. Cytokines activated by the LPS-TLR4-NF-кB signaling pathway can induce HCC by stimulating precancerous hepatocellular proliferation [302]. The development of hepatic cancer may also involve secondary bile acids, which are products of the bacterial metabolism of primary bile acids. These compounds influence the liver immune system [303,304], suppressing antitumor immunity, and promoting the progression of liver cancer. This suppression is believed to act through the prostaglandin E receptor on CD8 T cells [305].

\subsection{The Human Gut Microbiota and Cancers of Urogenital System}

The healthy urinary tract has been considered sterile, and the presence of bacteria was treated as some type of infection in the urinary tract. It is widely accepted that urine is hostile to the survival of microorganisms. The composition of the urinary microbiome differs between men and women. For example, female urine samples demonstrate a more heterogenous composition of bacterial composition, with E. coli being observed in $91 \%$ of healthy adult women, and only in $25 \%$ of men; in addition, the members of Actinobacteria (e.g., Actinomyces, Arthobacter) and Bacteroidetes (e.g., Bacteroides) are present in female urine samples, but not in male urine samples [306]. Further differences in the composition of urine microbiota between men and women have been given elsewhere [307].

Although little concrete data exist on the association between microbiome and kidney cancer; it has been proposed that some viral infections may influence the development of renal cancer. However, the evidence is controversial and sometimes contradictory.

\subsubsection{Human Microbiota and Bladder Cancer}

Bladder cancer is the most prevalent malignancy of the urinary system [308,309], and is most commonly observed in men. However, although some associations have been suggested, no hard evidence exists to link dysbiosis of the urinary tract microbiota with bladder cancer [310].

Several investigations have indicated differences in the composition of urine microbiota between patients with bladder cancer and healthy subjects. For example, the urine samples of cancer patients demonstrated higher average number genera in comparison with healthy subjects, with the predominant genera being Acinetobacter and Streptococcus. The urinary samples of patients with bladder cancer demonstrate higher levels of Actinomyces, especially A. europaeus, as compared to those of healthy subjects [311]. While no significant differences in microbial diversity or overall microbiota composition were found between urine samples from male patients with bladder cancer and healthy controls, the former were found to demonstrate bacteria of the genus Fusobacterium, a possible pro-tumorigenic pathogen, while the latter were more abundant in the genera Veillonella, Streptococcus, and Corynebacterium. [308]. In the urine of cancer patients with high risk of recurrence and progression of bladder cancer, researchers observed the enrichment of Herbaspirillum, Porphyrobacteria, and Bacteroides [310]. Other studies have also described differences in the composition of urine microbiome between cancer patients and healthy subjects [312]. Interestingly, the condition of the bladder microbiota may prevent of the recurrence superficial bladder cancer, as is observed in the case of Lactcaseibacillus casei [313].

\subsubsection{Human Microbiota and Ovarian Cancer}

Epithelial ovarian cancer (OC) is the second deadliest cancer of the female reproductive system [314]. One reason for this high mortality rate is the lack an effective screening method for early detection of OC; as such, more than $60 \%$ of cases are diagnosed at an advanced stage [315]. It has been proposed that the peritoneal inflammation caused by OC 
may be a possible mechanism for cancer metastasis [316,317]. While studies suggest that Chlamydia trachomatis and Mycoplasma genitalium may play a part in the development of OC [318], few studies have described the association between microbiota composition and ovarian cancer.

As human microbiota can alter the metabolism of estrogen, they may suppress or promote estrogen-derived cancers [319,320]. In addition, it is possible that OC influences the composition of local microbiota, thus altering its microbial environment. Investigations of peritoneal fluid from patients with advanced OC, III and IV stages revealed the presence of various bacteria that may be associated with disease pathogenesis. These included the Rikenellaceae (phylum Bacteroidetes), known as estrogen responsive, Alphaproteobacteria (phylum Proteobacteria), involved in vascular permeability, and Akkermansia muciniphila (phylum Verrucomicrobia), which show anti-inflammatory properties. The authors add a list of 18 microbial features, that appear to be closely associated with the pathology of $\mathrm{OC}$, and suggest that the composition of peritoneal microbiota may be important for the diagnosis of OC [315]. Elsewhere, in samples of ovarian cancer found to demonstrate Brucella [321], Mycoplasma, in 59\% of the ovarian cancer tissue samples [322], and Chlamydia, in $70 \%$ [323]. These bacteria were not detected in healthy subjects [323]. Other studies have noted the presence of Streptococcus, Stphylococcus, Bacillus, Pediococcus, Chyseobacterium, Fusobacterium, Prevotella, Salmonella, Escherichia, and Treponema in ovarian cancer samples [314]. Most importantly, these bacteria are also associated with other cancers.

Associations have been noted between the profile of the cervicovaginal microbiome, BRCA1 mutations, and the risk of OC [324]. In addition, it was found that a microbiome in which Lactobacillus crispatus, L. iners, L. gasseri, and L. jensenii account for at least $50 \%$ of the bacterial species may protect against ovarian cancer. If Lactobacillus spp. accounted for less than $50 \%$ of all bacterial genera detected, this microbial composition may be involved in development of OC [324]. Lactobacillus spp. Also plays a protective role against vaginal infection and inflammation [325].

\subsubsection{Human Microbiota and Cervical Cancer}

The risk of development of cervical cancer is increased by infection with human papillomavirus (HPV) [326]. Women infected with HPV have greater bacterial diversity [327], and are specifically abundant in Lactobacillus gasseri and Gardnerella vaginalis. A higher level of HPV was associated with a lower level of Lactobacillus and greater vaginal microbiome diversity [328]; in addition, the level of Sneathia was found to closely correlate with HPV infection [329]; furthermore, an elevated level of L. gasseri or L. iners correlated with rapid remission of $\mathrm{HPV}$, and microbiota with low levels of Lactobacillus spp. And a high level of Atopobium, demonstrated slower HPV clearance [327]. It has also been proposed that Chlamydia trachomatis may change the microbiome and predispose women to HPV infection [330].

Regarding the association between the vaginal microbiome and cervical intraepithelial neoplasia, it has been suggested that Lactobacillus iners may be associated with intraepithelial neoplasia [331] and with HPV infection [332]. In HPV-positive women, this bacterium is associated with higher grades of cervical intraepithelial neoplasia [333]. L. iners has also been found to decrease the risk of squamous intraepithelial lesions and cervical cancer. Other studies report that various other bacteria, such as Atopobium vaginae, G. vaginalis and Fusobacterium spp., are also associated with cervical intraepithelial neoplasia [331,332,334,335].

\subsubsection{Human Microbiota and Prostate Cancer}

Prostate cancer (PCa) is one of the most common cancers, and the second leading cause of death in men [262]. Its development is closely linked with the activity of androgen hormones; however, other factors, such as diet and lifestyle, may be involved [336]. A possible association between microbiota and prostate cancer has long been discussed. Chronic inflammation has been proposed to play a role in prostate carcinogenesis [337]. 
As Helicobacter pylori is known to induce chronic inflammation, inducing stomach cancer, it has been suggested that it, and other pro-inflammatory species of Helicobacter, may also be involved in prostate carcinogenesis [338]. Indeed, Gram-negative bacteria such as E. coli, Pseudomonas aeruginosa, and Enterococcus are frequently observed in urinary tract infection, and infections of E. coli and Enterococcus are characterized by higher levels of pro-inflammatory cytokines [339].

Patients undergoing transrectal prostate biopsy demonstrated increased levels of pro-inflammatory bacteria, such as Bacteroides and Streptococcus, in the rectal microbiome compared to healthy subjects. Samples from these patients are characterized by elevated numbers of bacteria associated with carbohydrate metabolism, and lower numbers of those associated with folate, biotin, and riboflavin metabolism [340]. In samples of tumoral, peritumoral, and non-tumoral tissue obtained after radical prostatectomy, the dominant phyla were Actinobacteria, Firmicutes, and Propionibacteria; however, higher levels of Staphylococcus spp. in tumor and peri-tumor samples [341]. Increased levels of Propionibacterium acnes have also been noted in samples of prostate cancer [342].

Mycoplasma genitalium may induce oncogenic transformation. A study of various sexually transmitted infectious agents found only M. genitalium to be independently associated with higher stage cancers [343,344]. In addition, elevated levels of Bacteroidetes, Alphaproteobacteria, Firmicutes, Lachnospiraceae, Propionicimonas, Sphingomonas, and Ochrobacterium bacteria have been noted in prostatic secretions of patients with PCa. Increased levels of $E$. coli were noted in seminal fluid and prostatic secretion, and lower levels in urine samples. Among patients with prostate cancer, those with benign prostatic hyperplasia were characterized by lower counts of Eubacterium and Defluviicoccus [345].

\subsection{Human Microbiota and Lung Cancer}

Lung cancer (LC) is the most common and lethal cancer worldwide, causing up to $23.1 \%$ of deaths due to all cancers $[169,346]$. The most prevalent type of LC is non-small cell lung cancer (NSCLC), which is subdivided into two major subtypes: adenocarcinoma (ADC) and squamous cell carcinoma (SCC). These subtypes are characterized by different biological patterns, molecular biology, and treatment strategies. Although LC is believed to be closely associated with chronic inflammation, the causes of this inflammation remain unclear [347].

The composition of the lung microbiota also remains poorly studied [348]. However, while the lung has long been regarded as a sterile space, it has recently been suggested that it does have its own microbiota, comprising approximately $2.2 \times 10^{3}$ bacterial genomes $/ \mathrm{cm}^{2}$ [349]. The majority of microbes that residue in the human lung belong to four phyla: Bacteroidetes, Firmicutes, Proteobacteria, and Actinobacteria, with the two main phyla in healthy lung microbiota being Bacteroidetes and Firmicutes [350]. The most abundant genera in the human lung are Prevotella, Streptococcus, Veillonella, Neisseria, Haemophilus, and Fusobacterium [351], whereas the most common in the lower respiratory system are Pseudomonas, Streptococcus, Fusobacterium, Megasphaera, and Sphingomonas [352].

Various diseases have the potential to cause dysbiosis of the lung microbiota, and it has been suggested that the composition of lung microbiota should be analyzed separately with regard to each [353]. It has been found that Acidovorax, Klebsiella, Rhodoferax, Comamonas, and Polarmonas are more frequently detected in small-cell carcinoma, but were not detected in ADC samples [354]. Another study showed a correlation between ADC and the presence of Pseudomonas [355], and Capnocytophaga, Selenomonas, Veillonella, and Neisseria were found in saliva samples from patients with small-cell carcinoma and those with ADC [356]. The presence of Granulicatella adiacens, Enterococcus spp., Streptococcus intermedius, S. viridans, Streptococcus spp., E. coli, and Acinetobacter junii was also observed in samples of lung cancer, but not in lung tissue samples from healthy controls [357].

A correlation was also found between the presence of emphysema in patients with LC and the composition of microbiota. The patients with LC and emphysema demonstrated higher levels of Firmicutes (Streptococcus) and Bacteroidetes (Prevotella) than those with 
emphysema only. Patients with LC cases were found to be less likely to demonstrate the phylum Proteobacteria (Acinetobacter and Acidovorax), regardless of emphysema [358].

A relationship was also found between lung microbiota composition and distant metastasis of LC in patients with SCC and ADC [353]. Among patients with ADC, those without distant metastasis demonstrated higher counts of phylum Firmicutes and genus Streptococcus than those with distant metastasis, suggesting that Streptococcus may play a protective role in LC. Among the patients with SCC, those with distant metastasis demonstrated increased levels of Veillonella and Rothia than those without metastasis. Among the patients without distant metastasis, significantly higher levels of genera Veillonella, Megasphaera, Actinomyces, and Arthrobacter were observed in the ADC patients, while among those with distant metastasis, patients with SCC were characterized by significantly higher counts of the genera Capnocytophaga and Rothia [353].

An association has been described between gut microbiota dysbiosis and lung cancer. Fecal samples from patients with LC demonstrated less diverse microbial ecosystems compared to healthy controls: lower levels of Firmicutes and Actinobacteria and a higher abundance of Proteobacteria and Verrucomicrobia compared with healthy controls [346]. In another study, significant differences in $\beta$-diversity were found between LC patients and healthy controls; the former contained lower levels of Actinobacteria and Bifidobacterium and higher levels of Enterococcus compared with healthy controls [359].

Many studies have noted differences in the composition of lung microbiota between LC patients and healthy subjects. The composition of lung microbiota is believed to depend also on LC subtype [360], antibiotic use [361], sample site (gut, lung, upper airways) [362], smoking status, and tumor type/grade [363,364].

In addition, the composition of lung microbiota may be associated with LC prognosis. For example, among patients with NSCLC, a greater diversity of lung commensal bacteria in unaffected distal tissues is associated with reduced disease free (DSF) and recurrencefree (RFS) survival. Higher levels of Koribacter aceae are associated with increased DSF and RFS, and greater occurrence of Bacteroidaceae, Lechnospiraceae, and Ruminococcaceae, with lower RFS and DSF [365]. Several of these results have been confirmed in animal studies [366,367].

\subsection{Human Microbiota and Melanoma}

Although melanoma is the least common cancer of the skin, it is responsible for the most deaths. The skin microbiota plays an important role in human health. Healthy human skin contains up to $10^{7}$ microorganisms $/ \mathrm{cm}^{2}$, and is believed to include more than 1000 bacterial species belonging to 19 phyla [368]. The predominant genera are Propionibacteria, Streptococcus, and Corynebacterium [369]; however, the composition is influenced by several factors, including skin sites, sexual maturity, skin physiology, and age [370]. For example, young children demonstrate high levels of Streptococcus, Rothia, Gemella, Granulicatela, and Haemophilus, while adults are more associated with Propionibacterium, Lactobacillus, Anaerococcus, Finegoldia, and Corynebacterium. In addition, children tend to have more diverse skin microbiota than adults [371].

Few studies have examined the possible link between human microbiota and skin cancer. Nevertheless, it has been suggested that Fusobacterium nucleatum may be involved in the development of melanoma, and that the composition of gut microbiota may be influenced by immunotherapy in patients with melanoma [372]. Longer progression-free survival (PFS) is observed in the patients with more diverse microbial communities with higher numbers of Faecalibacterium prausnitzii, Coprococcus eutactus, Prevotella stercorea, Streptococcus sanguinis, S. anginosus, and Lachnospiraceae bacterium 31 46FAA, while shorter PFS was associated with higher counts of Bacteroides ovatus, B. dorei, B. massiliensis, Ruminococcus gnavus, and Blautia product. [372]. The association between the composition of human skin and gut microbiota and the development of melanoma needs further investigations. 


\subsection{Human Microbiota and Breast Cancer}

Breast cancer (BC) is the most common cancer among women worldwide, and it is the second most common cause of death in women. BC is not believed to be directly associated with dysbiosis of gut microbiota.

Recently obtained results indicate that breast tissue has a specific microbiome which differs from those of other tissue. Significantly higher levels of Prevotella, Lactobacillus, Streptococcus, Corynebacterium and Micrococcus were detected in breast tissue samples of women free of $B C$ who underwent either breast reduction or enhancement, compared to women with BC [373]. The composition of human breast tissue and milk microbiota are almost similar. The most abundant phyla in both breast tissue and milk are Firmicutes, Actinobacteria, and Bacteroidetes [374,375].

It is possible that microbial dysbiosis may play a role in the development of BC. Higher levels of Bacillus, Staphylococcus, and unclassified Enterobacteriaceae, Comamonadaceae, Bacteroidetes were noted in samples of breast tissue from women who underwent lumpectomies or mastectomies for either benign or cancerous tumors, compared with women without cancer [373]. In addition, breast tissue appears to have a similar microbiome between benign and invasive BC, being dominated by Bacteroidetes and Firmicutes, with an increased abundance of certain genera, including Fusobacterium, Atopobium, Gluconacetobacter, Hydrogenophagea, and Lactobacillus [376]. It was found also that the composition of microbiota in the urinary tract of women with BC differs from those of women without BC. However, the two groups demonstrated similar oral cavity microbiota [362,377]. Several studies have noted an association between dysbiosis and the development of BC [378-381].

\section{Role of Gut Microbiota in Anti-Cancer Therapy}

Gut microbiome dysbiosis is associated with several diseases, including cancers. Furthermore, the gut microbiota may modulate the host response to therapies administered in cancers, such as immunotherapy, chemotherapy, or radiotherapy. It is hence possible that an altered gut microbiome composition may have a beneficial effect in anti-cancer therapy [382-384].

Literature on anticancer therapies is very rich. There are described several therapies, such as immunotherapy, radiotherapy, and chemotherapy. There are also molecular techniques in which microRNA (miRNA), short hairpin (shRNA), small interfering (siRNA) and antisense cDNA are used. As an anticancer therapy, they are investigated (in laboratories and clinics) and used natural inhibitors, such as polyphenols, obtained from plants, and synthetic inhibitors, such as BAY876, WZB117, Glutor, fasentin, and several other (Reviewed by Pliszka and Szablewski, 2021 [385]). Unfortunately, literature on the role of gut microbiota as an anti-cancer therapy is poor. Little is known on this subject. Therefore, this paragraph, despite being very important, is very poor.

\subsection{Immunotherapy}

In 1890, William Coley injected a patient with terminal sarcoma of bacteria, referred to as "Coley's toxin". This procedure induced an anti-cancer effect, and saved the life of the patient [386]. Coley's toxin contained heat-killed Staphylococcus pyogenes and Serratia marcescens. Unfortunately, this bacterial combination used in therapy was only effective in a small proportion of patients [387]. Nevertheless, Coley's observations prompted other clinical oncologists to examine the use of microbial agents or their products as anti-cancer therapy, with varying degrees of success. In one case, the attenuated form of Mycobacterium bovis was administered to patients with bladder cancer [388], and Listeria monocytes was used as an anti-cancer therapy in pancreatic cancer [389].

Different responses to anti-programmed death-1 (anti-PD-1) therapy were observed in patients with metastatic melanoma, which were believed to be associated with the composition of gut microbiota in these patients. The responding $(R)$ patients demonstrated higher relative abundance of Faecalibacterium prausnitzii compared to non-responding (NR) [390]. Patients with high counts of Clostridiales, Ruminococcaceae, or Faecalibacterium 
demonstrated increased levels of effector $\mathrm{CD} 4^{+}$and $\mathrm{CD} 8^{+} \mathrm{T}$ cells in the systemic circulation; in addition, higher levels of Bacteroidales in the gut microbiota caused higher levels of Tregs and myeloid-derived suppressor cells (MDSCs) [390].

The effectiveness of anti-PD-1 therapy depends also on increased levels of Bifidobacterium longum [391], and the responses of patients with non-small lung cancer to PD-1 therapy were found to be dependent on the composition of gut microbiota. R patients displayed a higher abundance of Akkermansia muciniphila in comparison with NR patients, while NR patients displayed higher levels of Corynebacterium aurimucosum and Staphylococcus haemolyticus [392]. These results suggest that, in the case of PD-1 therapy, an important role is played by the composition of the human gut microbiota [393]; however, the mechanism of this dependence remains unclear [394].

\subsection{Chemotherapy}

Gut microbiota can influence the efficacy of chemotherapy by several mechanisms, such as xenometabolism, immune reactions, and altered community structure [395], and can modify or metabolize anti-cancer drugs. It has been found that 5-fluorouracil (5-FU)sorivudine, used in anti-cancer bi-therapy, may be metabolized by Bacteroides spp.; this inhibits the degradation of 5-FU, resulting in its accumulation in the blood and potentially the death of the patient. In addition, some bacteria, such as Bacteroides spp., Faecalibacterium prausnitzii, and Clostridium spp., can increase the toxicity of cancer therapy by producing $\beta$-glucoronidase. These bacteria can also increase the toxic effects of the topoisomerase I inhibitor irinotecan, an anti-cancer drug used in pancreatic and colorectal cancer; the drug itself is a prodrug that is metabolized into the active agent SN38. The presence of the bacteria can result in increased SN38 levels, resulting in serious diarrhea [393,396,397]. Gut microbiota have also been implicated in side effects in chemotherapy for other cancers, such as melanoma, lung cancer, colon cancer, and sarcoma.

Gut microbiota may also bestow a beneficial effect on chemotherapy. One commonly used chemotherapy drug is cyclophosphamide (CP). CP induces the translocation of commensal bacteria into secondary lymph organs, influencing the maturity of $\mathrm{T}$ helper 17 cells and shifting to the Th1 immune response. The immune responses facilitate a systemic anti-tumor effect [398]. The influence of gut microbiota on chemotherapy has been confirmed in a number of animal studies, particularly those based on Gram-positive bacteria, such as Enterococcus hirae, Lactobacillus johnsonii, Ligilactobacillus murinus, and segmented filamentous bacteria [398]. Animal studies have also revealed that the effect of platinum-based anti-cancer drugs, such as oxaliplatin or cisplatin, is enhanced by Lactobacillus acidophilus, restoring the anti-tumor activity of cisplatin in resistant cases [399]. Other studies have examined the interaction between microbiota and chemotherapeutic compounds [166].

\subsection{Radiotherapy}

Radiotherapy, or ionizing radiation therapy (RTX), is commonly used for patients with solid cancers. Unfortunately, RTX alters the microbiota composition.

Patients receiving RTX often demonstrate various pathologies, such as oral mucositis, enteritis, and diarrhea, which are believed to occur in response to changes in the composition of the epithelial surface microbiota. Studies suggest that irradiation-mediated intestinal toxicity is regulated by Toll-like receptor-3 (TLR3); therefore, the suppression of TLR3 signaling may decrease the gastrointestinal damage due to radiotherapy. This beneficial effect was observed after the administration of mixtures of B. bifidum, L. acidophilus, $L$. casei, Streptococcus spp., which are believed to reduce radiation-induced gut toxicity. Animal studies indicate that the orally administered Streptococcus, Lactobacillus, and Bifidobacterium spp. mixture protects animal models against toxicity due to radiotherapy [393]. 


\subsection{Probiotics}

Most studies are focused on the role of gut microbiota in the inhibition of cancer development, or on cancer therapy-related toxicity [400]. For example, probiotic VSL\#3, which contains eight strains of lactic-producing bacteria, protects against radiation-induced diarrhea [401,402]. Several studies describe the beneficial role of probiotics in reducing side effects associated with anti-cancer therapy. The results obtained in humans have been confirmed in animal models. For example, L. casei may inhibit the progression of colon cancer, inducing apoptosis [403]. VSL\#3 was found to induce anti-angiogenic effects and reduce inflammation, thus preventing the progression of subcutaneous hepatocellular carcinoma in an animal model [404]. However, further larger controlled clinical trials are needed on the beneficial effects of probiotics in cancer therapy [167].

\subsection{Prebiotics}

Prebiotics are typically substances intended as food for intestinal bacteria. Metabolized prebiotics act as tumor suppressive metabolites [21]. For example, polysaccharides may be metabolized to SCFAs, increasing the share of Bifidobacterium spp., [405], which inhibits the growth of cancer, and facilitates anti-PD-L1 efficacy. Herbal supplements may be metabolized into anti-cancer compounds. Animal studies suggest that metabolites of American ginseng may attenuate colon carcinogenesis; these metabolites decrease the abundance of Gram-negative bacteria, such as Bacteroidales and Verrucomicrobia, that are involved in tumorigenesis, and increase the abundance of Gram-positive bacteria, such as Firmicutes, which have an anti-tumorigenic role [406]. The beneficial roles of prebiotics in anti-cancer therapy have been described elsewhere [108].

\subsection{Synbiotics}

Synbiotics are the combination of probiotics and prebiotics. Few studies have been performed on the role of this mixture in cancer therapy. Patients with periampullary cancers undergoing curative or palliative treatment were treated with a mixture containing Lactobacillus acidophilus, Lacticaseibacillus rhamnosus, Lacticaseibacillus casei, and Bifidobacterium bifidum as a probiotic, and fructooligosaccharides as a prebiotic. These patients demonstrated decreased postoperative mortality and complication rates [407]. Clearly, the use of pre- and synbiotics in anti-cancer therapy requires more studies [397].

\subsection{Fecal Microbiota Transplantation}

This method, while less accepted by patients, has also been suggested for treating cancer. Animal studies suggest that FMT reduces colorectal carcinogenesis [408]; however, it is unclear whether this method reduces carcinogenesis and tumor progression in humans. Therefore, several clinical trials in which FMT is used in patients with cancer are currently ongoing [167].

\section{Summary}

Human microbiota, particularly those of the gut, influence human health and disease. These microbes play an important role in a range of processes, such as digestion, modulation of immunity, and cytokine production, and are generally beneficial to human life. On the other hand, disturbances in the balance between symbionts, commensals and pathobionts, known as dysbiosis, may influence the course of several diseases, including cancer. Such changes in the composition of gut microbiota may occur in response to several factors, such as diet, disease and pharmacology. As such, human and animal health are strongly dependent on maintaining the homeostasis of microbiota composition.

Author Contributions: Conceptualization, original draft preparation, review and editing-A.S. and L.S. These authors contributed equally to this work. All authors have read and agreed to the published version of the manuscript. 
Funding: This research did not receive any specific grant from funding agencies in the public, commercial, or not-for-profit sectors.

Institutional Review Board Statement: Not applicable.

Informed Consent Statement: Not applicable.

Data Availably Statement: All data presented in article are available in cited articles.

Conflicts of Interest: The authors declare no conflict of interest.

\section{References}

1. Chen, Z.; Zhu, S.; Xu, G. Targeting gut microbiota: A potential promising therapy for diabetic kidney disease. Am. J. Transl. Res. 2016, 8, 4009-4016.

2. Pokrzywnicka, P.; Gumprecht, J. Intestinal microbiota and its relationship with diabetes and obesity. Clin. Diabetol. 2016, 5, 164-172. [CrossRef]

3. Koboziev, I.; Webb, C.R.; Furr, K.L.; Grisham, M.B. Role of the enteric microbiota in intestinal homeostasis and inflammation. Free Rad. Biol. Med. 2014, 68, 122-133. [CrossRef]

4. Schloss, P.D.; Handelsman, J. Status of the microbial census. Microb. Mol. Biol. Rev. 2004, 68, 686-691. [CrossRef]

5. Bull-Larsen, S.; Mohajeri, M.H. The potential influence of the bacterial microbiome on the development and progression of ADHD. Nutrients 2019, 11, 2805. [CrossRef]

6. Principi, N.; Esposito, S. Gut microbiota and central nervous system development. J. Infect. 2016, 73, 536-546. [CrossRef] [PubMed]

7. Muñoz-Garach, A.; Diaz-Perdigones, C.; Tinahones, F.J. Gut microbiota and type 2 diabetes mellitus. Endocrinol. Nutr. 2016, 63, 560-568. [CrossRef]

8. $\quad$ Findley, K.; Oh, J.; Yang, J.; Conlan, S.; Deming, C.; Meyer, J.A.; Schoenfeld, D.; Nomicos, E.; Park, M.; NIH Intramural Sequencing Center Comparative Sequencing Program; et al. Topographic diversity of fungal and bacterial communities in human skin. Nature 2013, 498, 367-370. [CrossRef]

9. Oh, J.; Byrd, A.L.; Park, M.; Kong, H.H.; Segre, J.A.; NISC Comparative Sequencing Program. Temporal stability of the human skin microbiome. Cell 2016, 165, 854-866. [CrossRef]

10. Mukherjee, P.K.; Sendid, B.; Hoarau, G.; Colombel, J.-F.; Poulain, D.; Ghannoum, M.A. Mycobiota in gastrointestinal diseases. Nat. Rev. Gastroenterol. Hepatol. 2015, 12, 77-87. [CrossRef] [PubMed]

11. Ghannoum, M.A.; Jurevic, R.J.; Mukherjee, P.K.; Cui, F.; Sikaroodi, M.; Naqvi, A.; Gillevet, P.M. Characterization of the oral fungal microbiome (mycobiome) in healthy individuals. PLoS Pathog. 2010, 6, e1000713. [CrossRef]

12. Mukherjee, P.K.; Chandra, J.; Retuerto, M.; Sikaroodi, M.; Brown, R.E.; Jurevic, R.; Salata, R.A.; Lederman, M.M.; Gillevet, P.M.; Ghannoum, M.A. Oral microbiome analysis of HIV-infected patients: Identification of Pichia as an antagonist of opportunistic fungi. PLoS Pathog. 2014, 10, e1003996. [CrossRef]

13. Hallen-Adams, H.E.; Suhr, M.J. Fungi in the healthy human gastrointestinal tract. Virulence 2017, 8, 352-358. [CrossRef]

14. Illiev, I.D.; Leonardi, I. Fungal dysbiosis: Immunity and interactions at mucosal barriers. Nat. Rev. 2017, 17, 635-646. [CrossRef]

15. Szablewski, L. The Role of Microbiota in Human Health and Disease; Lambert Academic Publishing: Beau Bassin, Mauritius, 2020; p. 342.

16. Charlson, E.S.; Diamond, J.M.; Bittinger, K.; Fitzgerald, A.S.; Yadav, A.; Haas, A.R.; Bushman, F.D.; Collman, R.G. Lung-enriched organisms and aberrant bacterial and fungal respiratory microbiota after lung transplant. Am. J. Respir. Crit. Care Med. 2012, 186, 536-545. [CrossRef]

17. Drell, T.; Lillsaar, T.; Tummeleht, L.; Simm, J.; Aaspõllu, A.; Väin, E.; Saarma, I.; Salumets, A.; Donders, G.G.G.; Metsis, M. Characterization of the vaginal micro- and mycobiome is asymptomatic reproductive-age Estonian women. PLoS ONE 2013, 8 , e54379. [CrossRef]

18. Farr, A.; Kiss, H.; Holzer, I.; Husslein, P.; Hagmann, M.; Petrocevic, L. Effect of asymptomatic vaginal colonization with Candida albicans on pregnancy outcome. Acta Obstet. Gynecol. Scand. 2015, 94, 989-996. [CrossRef] [PubMed]

19. De Filippo, C.; Cavalieri, D.; Di Paola, M.; Ramazzotti, M.; Poullet, J.B.; Massart, S.; Collini, S.; Pieraccini, G.; Lionetti, P. Impact of diet in shaping gut microbiota revealed by a comparative study in children from Europe and rural Africa. Proc. Natl. Acad. Sci. USA 2010, 107, 14691-14696. [CrossRef]

20. Tremaroli, A.; Bäckhed, F. Functional interactions between the gut microbiota and host metabolism. Nature 2012, 489, 242-249. [CrossRef]

21. Louis, P.; Hold, G.L.; Flint, H.J. The gut microbiota, bacterial metabolites and colorectal cancer. Nat. Rev. Microbiol. 2014, 12, 661-672. [CrossRef] [PubMed]

22. Musso, G.; Gambino, R.; Cassader, M. Obesity, diabetes and gut microbiota. The hygiene hypothesis expanded. Diabet. Care 2010, 33, 2277-2284. [CrossRef]

23. Nicholson, J.K.; Holmes, E.; Kinros, J.; Burcelin, R.; Gibson, G.; Jia, W.; Pettersson, S. Host-gut microbiota metabolic interactions. Science 2012, 336, 1262-1267. [CrossRef] 
24. Louis, P.; Flint, H.J. Formation of propionate and butyrate by the human colonic microbiota. Environ. Microbiol. $2017,19,29-41$. [CrossRef]

25. Duncan, S.H.; Louis, P.; Thomson, J.M.; Flint, H.J. The role of $\mathrm{pH}$ in determining the species composition of the human colonic microbiota. Environ. Microbiol. 2009, 11, 2112-2122. [CrossRef] [PubMed]

26. Morrison, D.J.; Preston, T. Formation of short chain fatty acids by the gut microbiota and their impact on human metabolism. Gut Microb. 2016, 7, 189-200. [CrossRef]

27. Thorburn, A.N.; McKenzie, C.I.; Shen, S.; Stanley, D.; Macia, L.; Mason, L.J.; Roberts, L.K.; Wong, C.H.Y.; Shim, R.; Robert, R.; et al. Evidence that asthma is a developmental origin disease influenced by maternal diet and bacterial metabolites. Nat. Commun. 2015, 6, 7320. [CrossRef]

28. Schilderink, R.; Verseijden, C.; de Jonge, W.J. Dietary inhibitors of histone deacetylases in intestinal immunity and homeostasis. Front. Immunol. 2013, 4, 226. [CrossRef]

29. Davie, J.R. Inhibition of histone deacetylase activity by butyrate. J. Nutr. 2003, 133, 2485S-2493S. [CrossRef]

30. Vinolo, M.A.R.; Rodrigues, H.G.; Nachbar, R.T.; Curi, R. Regulation of inflammation by short chain fatty acids. Nutrients 2011, 3 , 858-876. [CrossRef]

31. Arvans, D.I.; Vavricka, S.R.; Ren, H.; Musch, M.W.; Kang, L.; Rocha, F.G.; Lucioni, A.; Turner, J.R.; Alverdy, J.; Chang, E.B. Luminal bacterial flora determines physiological expression of intestinal epithelial cytoprotective heat shock protein 25 and 72 . Am. J. Physiol. Gastrointest. Liver Physiol. 2005, 288, G696-G704. [CrossRef]

32. De Vadder, F.; Kovtcheva-Datchary, P.; Goncalves, D.; Vinera, J.; Zitoun, C.; Duchampt, A.; Bäckhed, F.; Mithieux, G. Microbiotagenerated metabolites promote metabolic benefits via gut-brain neural circuits. Cell 2014, 156, 84-96. [CrossRef] [PubMed]

33. Grüner, A.; Mattner, J. Bile acids and microbiota multifaceted and versatile regulators of the liver-gut axis. Int. J. Mol. Sci. 2021, 22, 1397. [CrossRef] [PubMed]

34. Schroeder, B.O.; Bäckhed, F. Signals from the gut microbiota to distant organs in physiology and disease. Nat. Med. 2016, 22, 1079-1089. [CrossRef] [PubMed]

35. Wang, H.; Chen, J.; Holister, K.; Sowers, L.C.; Forman, B.M. Endogenous bile acids are ligands for the nuclear receptor FXR/BAR. Mol. Cell. 1999, 4, 543-553. [CrossRef]

36. Prawitt, J.; Abdelkarim, M.; Stroeve, J.H.; Iuliana Popescu, I.; Duez, H.; Velagapudi, V.R.; Dumont, J.; Bouchaert, E.; van Dijk, T.H.; Lucas, A.; et al. Farnesoid X receptor deficiency improves glucose homeostasis in mouse models of obesity. Diabetes 2011, 60, 1861-1871. [CrossRef]

37. Thomas, C.; Gioiello, A.; Noriega, I.; Strehle, A.; Oury, J.; Rizzo, G.; Macchiarulo, A.; Yamamoto, H.; Mataki, C.; Pruzanski, M.; et al. TGR5-mediated bile acid sensing controls glucose homeostasis. Cell Metab. 2009, 10, 167-177. [CrossRef]

38. Broeders, E.P.M.; Nascimento, E.B.; Havekes, B.; Brans, B.; Roumans, K.H.M.; Tailleux, A.; Schaart, G.; Kouach, M.; Charton, J.; Deprez, B.; et al. The bile acid chenodeoxycholic acid increases human brown adipose activity. Cell Metab. $2015,22,418-427$. [CrossRef]

39. Salminen, S.; Bouley, C.; Boutron-Rualt, M.C.; Cummings, J.H.; Franck, A.; Gibson, G.R.; Isolauri, E.; Moreau, M.C.; Roberfroid, M.; Rowland, I. Functional food science and gastrointestinal physiology and function. Br. J. Nutr. 1998, 80 (Suppl. S1), S147-S171. [CrossRef]

40. Schuijt, T.J.; Lankelma, J.M.; Scicluna, B.P.; de Sousa e Melo, F.; Roelofs, J.J.T.H.; de Boer, J.D.; Hoogendijk, A.J.; de Beer, R.; de Vos, A.; Belzer, C.; et al. The gut microbiota plays a protective role in the host defense against pneumococcal pneumonia. Gut 2016, 65, 575-583. [CrossRef]

41. Round, J.L.; Mazmanian, S.K. The gut microbiota shapes intestinal immune responses during health and diasese. Nat. Rev. Immunol. 2009, 9, 313-323. [CrossRef]

42. Cebra, J.J. Influences of microbiota on intestinal immune system developments. Am. J. Clin. Nutr. 1999, 69, 10465-10515. [CrossRef] [PubMed]

43. Atharasi, K.; Tanoue, T.; Shima, T.; Imaoka, A.; Kuwahara, T.; Momose, Y.; Cheng, G.; Yamasaki, S.; Saito, T.; Ohba, Y.; et al. Induction of colonic regulatory T cells by indigenous Clostridium species. Nature 2011, 331, 337-341.

44. Huuskonen, J.; Suuronen, T.; Nuutinen, T.; Kyrylenko, S.; Salminen, A. Regulation of microglial inflammatory response by sodium butyrate and short-chain fatty acids. Br. J. Pharmacol. 2004, 141, 874-880. [CrossRef] [PubMed]

45. Cox, M.A.; Jackson, J.; Stanton, M.; Rojas-Triana, A.; Bober, L.; Laverty, M.; Yang, X.; Zhu, F.; Liu, J.; Wang, S.; et al. Short-chain fatty acids act as anti-inflammatory mediators by regulating prostaglandin $\mathrm{E}_{2}$ and cytokines. World J. Gastroenterol. 2009, 15, 5549-5557. [CrossRef] [PubMed]

46. Mazmanian, S.K.; Liu, C.H.; Tzianabos, A.O.; Kasper, D.L. An immunomodulatory molecule of symbiotic bacteria directs maturation of the host immune system. Cell 2005, 122, 107-118. [CrossRef] [PubMed]

47. Christensen, H.R.; Frokiaer, H.; Pestka, J.J. Lactobacilli differentially modulate expression of cytokines and maturation surface markers in murine dendritic cells. J. Immunol. 2002, 168, 171-178. [CrossRef]

48. Fink, L.N.; Zeuthen, L.H.; Christensen, H.R.; Morandi, B.; Frokiaer, H.; Ferrlazzo, G. Distinct gut-derived lactic bacteria elicit divergent dendritic cell mediated NK cell responses. Int. Immunol. 2007, 19, 1319-1327. [CrossRef]

49. Bouskra, D.; Brézillon, C.; Bérard, M.; Werts, C.; Varona, R.; Boneca, I.G.; Eberl, G. Lymphoid tissue genesis induced by commensals through NOD1 regulates intestinal homeostasis. Nature 2008, 456, 507-510. [CrossRef] 
50. Wang, C.; McDonald, K.G.; McDonough, J.S.; Newberry, R.D. Murine isolated lymphoid follicles contain follicular B lymphocytes with a mucosal phenotype. Gastrointest. Liver Physiol. 2006, 291, G595-G604. [CrossRef] [PubMed]

51. Maloy, K.J.; Powrie, F. Intestinal homeostasis and its breakdown in inflammatory bowel disease. Nature 2011, 474, 298-306. [CrossRef]

52. Clarke, T.B.; Davis, K.M.; Lysenko, E.S.; Zhou, A.Y.; Yu, Y.; Weiser, J.N. Recognition of peptidyglycan from the microbiota Nod1 enhances systemic innate immunity. Nat. Med. 2010, 16, 228-231. [CrossRef] [PubMed]

53. Barrett, E.; Ross, R.P.; O’Toole, P.W.; Fitzgerals, C.F.; Stanton, C. Gamma aminobutyric acid production by culturable bacteria from human intestine. J. Appl. Microbiol. 2012, 113, 411-417. [CrossRef] [PubMed]

54. Bravo, J.A.; Forsythe, P.; Chew, M.V.; Escaravage, E.; Savignac, H.M.; Dinan, T.G.; Bienenstock, J.; Cryan, J.F. Ingestion of Lactobacillus strain regulates emotional behavior and central GABA receptor expression in a mouse via the vagus nerve. Proc. Natl. Acad. Sci. USA 2011, 108, 16050-16055. [CrossRef]

55. Rieder, R.; Wisniewski, P.J.; Alderman, B.L.; Campbell, S.C. Microbes and mental health: A review. Brain Behav. Immun. 2017, 66, 9-17. [CrossRef] [PubMed]

56. Coven, P.; Sherwood, A.C. The role of serotonin and cognitive function: Evidence from recent studies and implications for understanding depression. J. Psychopharmacol. 2013, 27, 575-583.

57. Cryan, J.F.; Dinan, T.G. Mind-altering microorganisms: The impact of the gut microbiota on brain and behavior. Nat. Rev. Neurosci. 2012, 13, 701-712. [CrossRef] [PubMed]

58. Reigstad, C.S.; Salmonson, C.E.; Reiney, J.F., 3rd; Szurszewski, J.H.; Linden, D.R.; Sonnenburg, J.L.; Farrugia, G.; Kashyap, P. Gut microbes promote colonic serotonin production through an effect of short-chain fatty acids on enterochromaffin cells. FASEB J. 2015, 29, 1395-1403. [CrossRef] [PubMed]

59. Liu, X.; Cao, S.; Zhang, X. Modulation of gut microbiota-brain axis by probiotics, prebiotics and diet. J. Agric. Food Chem. 2015, 63, 7885-7895. [CrossRef] [PubMed]

60. Parashar, A.; Udayabanu, M. Gut microbiota regulates key modulators of social behavior. Europ. Neuropsychpharmacol. 2016, 26, 78-91. [CrossRef] [PubMed]

61. Zola, S.M.; Squire, L.R.; Teng, E.; Stefanacci, L.; Buffalo, E.A.; Clark, R.E. Impaired recognition memory in monkeys after damage limited to the hippocampal region. J. Neurosci. 2000, 20, 451-463. [CrossRef] [PubMed]

62. Gareau, M.G.; Wine, E.; Rodrigues, D.M.; Cho, J.H.; Whary, M.T.; Philpott, D.J.; Macqueen, G.; Sherman, P.M. Bacterial infection causes stress-induced memory dysfunction in mice. Gut 2011, 60, 307-317. [CrossRef] [PubMed]

63. Carlino, D.; De Vanna, M.; Tongiorgi, E. Is altered BDNF biosynthesis a general feature in patients with cognitive dysfunctions? Neuroscientist 2013, 19, 345-353. [CrossRef] [PubMed]

64. Valdes, A.M.; Walter, J.; Segal, E.; Spector, T.D. Role of the gut microbiota in nutrition and health. BMJ 2018, 361, k2179. [CrossRef] [PubMed]

65. Satokari, R.; Grönroos, T.; Laitinen, K.; Salminen, S.; Isolauri, E. Bifidobacterium and Lactobacillus DNA in the human placenta. Lett. Appl. Microbiol. 2009, 48, 8-12. [CrossRef]

66. Oh, K.J.; Lee, S.E.; Jung, H.; Kim, G.; Romero, R.; Yoon, B.H. Detection of ureoplasms by the polymerase chain reaction in the amniotic fluid of patients with cervical insufficiency. J. Perinat. Med. 2010, 38, 261-268. [CrossRef] [PubMed]

67. Steel, J.H.; Malatos, S.; Kennea, N.; Edwards, A.D.; Miles, L.; Duggan, P.; Reynolds, P.R.; Feldman, R.G.; Sullivan, M.H.F. Bacteria and inflammatory cells in fetal membranes do not always cause preterm labor. Pediatr. Res. 2005, 57, 404-411. [CrossRef]

68. Jiménez, E.; Fernández, I.; Marín, M.L.; Martín, R.; Odriozola, J.M.; Nueno-Palop, C.; Narbad, A.; Olivares, M.; Xaus, J.; Rodríguez, J.M. Isolation of commensal bacteria from umbilical cord blood of healthy neonates born by cesarean section. Curr. Microbiol. 2005, 51, 270-274. [CrossRef] [PubMed]

69. Hu, J.; Nomura, Y.; Bashir, A.; Fernandez-Hernandez, H.; Itzkowitz, S.; Pei, Z.; Stone, J.; Loudon, H.; Peter, I. Diversified microbiota of meconium is affected by maternal diabetes status. PLoS ONE 2013, 8, e78257. [CrossRef] [PubMed]

70. Jiménez, E.; Marín, M.L.; Martín, R.; Odriozola, J.M.; Olivares, M.; Xaus, J.; Fernández, L.; Rodríguez, J.M. Is meconium from healthy newborns actually sterile? Res. Microbiol. 2008, 159, 187-193. [CrossRef] [PubMed]

71. Aagard, K.; Ma, J.; Antony, K.M.; Ganu, R.; Petrosino, J.; Versalovic, J. The placenta harbers a unique microbiome. Sci. Transl. Med. 2014, 237, ra265.

72. Tamburini, S.; Shen, N.; Wu, H.C.; Clemente, J.C. The microbiome in early life: Implications for health outcomes. Natur. Med. 2016, 22, 713-722. [CrossRef] [PubMed]

73. Mandar, R.; Mikelsaar, M. Transmission of mother's microflora to the newborn at birth. Neonatology 1996, 69, 30-35. [CrossRef] [PubMed]

74. Dominiquez-Bello, M.G.; Costello, E.K.; Contreras, M.; Magris, M.; Hidalgo, G.; Fierer, N.; Knight, R. Delivery mode shapes the acquisition and structure of the initial microbiota across multiple body habitats in newborns. Proc. Natl. Acad. Sci. USA 2010, 107, 11971-11975. [CrossRef] [PubMed]

75. Huurre, A.; Kaliomaki, M.; Rautava, S.; Rinne, M.; Salminen, S.; Isolauri, E. Mode of delivery: Effects of gut microbiota and humoral immunity. Neonatology 2008, 93, 236-240. [CrossRef] [PubMed]

76. Turroni, F.; Peano, C.; Pass, D.A.; Foroni, E.; Severgnini, M.; Claesson, M.J.; Kerr, C.; Hourihane, J.; Murray, D.; Fuligni, F.; et al. Diversity of Bifidobacteria within the infant gut microbiota. PLoS ONE 2012, 7, e36957. [CrossRef] [PubMed] 
77. Morelli, L. Postnatal development of intestinal microflora as influenced by infant nutrition. J. Nutr. 2008, 138, 1791S-1795S. [CrossRef] [PubMed]

78. Penders, J.; Thijs, C.; Vink, C.; Stelma, F.F.; Snijders, B.; Kummeling, I.; van den Brandt, P.A.; Stobberingh, E.E. Factors influencing the composition of the intestinal microbiota in early infancy. Pediatrics 2006, 118, 511-521. [CrossRef] [PubMed]

79. Bezirtzoglou, E.; Tsiotsiasias, A.; Welling, G.W. Microbiota profile in feces of breast- and formula-fed newborns by using fluorescence in situ hybridization (FISH). Anaerobe 2011, 17, 478-482. [CrossRef] [PubMed]

80. Moreno-Indias, I.; Cardona, F.; Tinahones, F.J.; Queipo-Ortuño, M.I. Impact of the gut microbiota on the development of obesity and type 2 diabetes mellitus. Front. Microbiol. 2014, 5, 1-10. [CrossRef] [PubMed]

81. Biagi, E.; Nylund, L.; Candela, M.; Ostan, R.; Bucci, L.; Pini, E.; Nikkila, J.; Monti, D.; Satokari, S.; Franceschi, C.; et al. Through ageing, and beyond: Status in seniors and centenarians. PLoS ONE 2010, 5, e10667. [CrossRef]

82. Illiano, P.; Brambilla, R.; Parolini, C. The mutual interplay of gut microbiota, diet and human disease. FEBS J. 2020, $287,833-855$. [CrossRef]

83. Martinez, J.E.; Kathana, D.D.; Ghuman, S.; Wilson, H.P.; Wilson, J.; Kim, S.C.J.; Lagishetty, V.; Jacobs, J.P.; Sinha-Hikim, A.P.; Friedman, T.C. Unhealthy lifestyle and gut dysbiosis: A better understanding the effects of poor diet and nicotine on the intestinal microbiome. Front. Endocrinol. 2021, 12, 667066. [CrossRef]

84. Weir, T.L.; Trikha, S.R.J.; Thompson, H.J. Diet and cancer risk reduction: The role of diet-microbiota interactions and microbial metabolites. Sem. Canccer Biol. 2021, 70, 53-60. [CrossRef] [PubMed]

85. Westman, E.C.; Feineman, R.D.; Mavropoulos, J.C.; Vernon, M.C.; Volek, J.S.; Wortman, J.A.; Yancy, W.S.; Phinney, S.D. Lowcarbohydrate nutrition and metabolism. Am. J. Clin. Nutr. 2007, 86, 276-284. [CrossRef] [PubMed]

86. Eaton, S.B. The ancestral human diet: What is it and should it be a paradigm for contemporary nutrition. Proc. Nutr. Soc. 2006, 65, 1-6. [CrossRef]

87. Dedoussis, G.V.Z.; Kaliora, A.C.; Panagiotakos, D.B. Genes, diet and type 2 diabetes mellitus. Rev. Diabet. Study 2007, 4, 13-24. [CrossRef] [PubMed]

88. Schnorr, S.L.; Candela, M.; Rampelli, S.; Centanni, M.; Consolandi, C.; Basaglia, G.; Turroni, S.; Biagi, E.; Peano, C.; Severgnini, M.; et al. Gut microbiome of the Hadza hunter-gatherers. Nat. Commun. 2014, 5, 3654. [CrossRef] [PubMed]

89. Bäckhed, F.; Ley, R.E.; Sonnenburg, J.L.; Peterson, D.A.; Gordon, J.L. Host bacterial mutualism in the human intestine. Science 2005, 307, 1915-1920. [CrossRef] [PubMed]

90. Bonder, M.J.; Tigchelaar, E.F.; Cai, X.; Trynka, G.; Cenit, M.C.; Hrdlickova, B.; Zhong, H.; Vatanen, T.; Gevers, D.; Wijmenga, C.; et al. The influence of a short-term gluten-free diet on the human gut microbiome. Genome Med. 2016, 8, 45. [CrossRef] [PubMed]

91. Singh, R.K.; Chang, H.-W.; Yan, D.; Lee, K.M.; Ucmak, D.; Wong, K.; Abrouk, M.; Farahnik, B.; Nakamura, M.; Zhu, T.H.; et al. Influence of diet on the gut microbiome and implications for human health. J. Transl. Med. 2017, 15, 73. [CrossRef]

92. Pineiro, M.; Stanton, C. Probiotic bacteria: Legislative framework requirement to evidence basis. J. Nutr. 2007, 137, 850S-853S. [CrossRef]

93. Gomes, A.C.; Bueno, A.A.; Machado de Souza, R.G.; Mota, J.F. Gut microbiota, probiotics and diabetes. Nutr. J. 2014, 13, 60. [CrossRef]

94. Angelakis, E.; Bastelica, D.; Amira, A.B.; Filari, A.E.; Dutour, A.; Mege, J.-L.; Alessi, M.-C.; Raoult, D. An evolution of the effects of lactobacillus ingluviei on body weight, the intestinal microbiome and metabolism in mice. Microb. Pathol. 2012, 52, 61-68. [CrossRef] [PubMed]

95. Takemura, N.; Okubo, T.; Sonoyama, K. Lactobacillus plantarum strain No. 14 reduces adipocyte size in mice fed high-fat diet. Exp. Biol. Med. 2010, 7, 849-856. [CrossRef]

96. Aronson, L.; Huang, Y.; Parini, P.; Korach-André, M.; Håkansson, J.; Gustafsson, J.-Å.; Pettersson, S.; Arulampalam, V.; Rafter, J. Decreased fat storage by Lactobacillus paracasei is associated with increased levels of Angiopoietin-like 4 protein (ANGPTL4). PLoS ONE 2010, 5, e13087. [CrossRef]

97. Chen, D.; Yang, Z.; Chen, C.; Huang, Y.; Yin, B.; Guo, F.; Zhao, H.; Zhao, T.; Qu, H.; Huang, J.; et al. Effect of Lactobacillus rhamnosus hsryfm 1301 on the intestinal microbiota of a hyperlipidemic rat model. BMC Compl. Altern. Med. 2014, 14, 386. [CrossRef]

98. Yadav, H.; Lee, J.H.; Lloyd, J.; Walter, P.; Rane, S.G. Beneficial metabolic effects of a probiotic via butyrate-induced GLP hormone secretion. J. Biol. Chem. 2013, 288, 25088-25097. [CrossRef]

99. Rao, A.V.; Bested, A.C.; Beaulne, T.M.; Katzman, M.A.; Iorio, C.; Berardi, J.M.; Logan, A.C. A randomized, double-blinded, placebo-controlled pilot study of a probiotic in emotional symptoms of chronic fatigue syndrome. Gut Pathol. 2009, 1, 6. [CrossRef]

100. Messaoudi, M.; Lalonde, R.; Violle, N.; Javelot, H.; Desor, D.; Nejdi, A.; Bisson, J.-F.; Rougeot, C.; Pichelin, M.; Cazaubiel, M.; et al. Assessment of psychotropic-like properties of a probiotic formulation (Lactobacillus helveticus R0052 and Bifidobacterium longum R0175) in rats and human subjects. Br. J. Nutr. 2011, 105, 755-764. [CrossRef]

101. Tillish, K.; Labus, J.; Kilpatrick, L.; Jiang, Z.; Stains, J.; Ebrat, B.; Guyonnet, D.; Legrain-Raspaud, S.; Trotin, B.; Naliboff, B.; et al. Consumption of fermented milk product with probiotc modulates brain activity. Gastroenterology 2013, 144, 1394-1401. [CrossRef] [PubMed]

102. Foligné, B.; Parayre, S.; Cheddani, R.; Famelart, M.H.; Madec, M.-N.; Plé, C.; Breton, J.; Dewulf, J.; Jan, G.; Deutsch, S.-M. Immunomodulation properties of multi-species fermented milk. Food Microbiol. 2016, 53, 60-69. [CrossRef] [PubMed] 
103. Rajkumar, H.; Mahmood, N.; Kumar, M.; Varikuti, S.R.; Challa, H.R.; Maakala, S.P. Effect of probiotic (VSL\#3) and omega-3 on lipid profile, insulin sensitivity, inflammatory markers and gut colonization in overweight adults: A randomized controlled trial. Med. Inflamm. 2014, 2014, 348959.

104. Wang, S.; Zhu, H.; Lu, C.; Kang, Z.; Luo, Y.; Feng, L.; Lu, X. Fermented milk supplemented with probiotics and prebiotics can effectively alter the intestinal microbiota and immunity of host animals. J. Dairy Sci. 2012, 95, 4813-4822. [CrossRef]

105. Liu, J.E.; Zhang, Y.; Zhang, D.; Dong, P.L.; Chen, M.; Duan, Z.P. Probiotic yogurt effects on intestinal flora of patients with chronic liver disease. Nurs. Res. 2010, 59, 426-432. [CrossRef] [PubMed]

106. Yang, Y.J.; Sheu, B.S. Probiotic-containing yogurts suppress Helicobacter pylori load and modify immune response and intestinal microbiota in the Helicobacter pylori-infected children. Helicobacter 2012, 17, 297-304. [CrossRef]

107. Roberfroid, M.; Gibson, G.R.; Hoyes, L.; McCartney, A.L.; Rastall, R.; Rowland, I.; Wolvers, D.; Watzl, B.; Szajewska, H.; Stahl, B.; et al. Prebiotic effects: Metabolic and health benefits. Br. J. Nutr. 2010, 104 (Suppl. S2), S1-S63. [CrossRef]

108. Fatima, N.; Akhtar, T.; Sheikh, N. Prebiotics: A novel approach to treat hepatocellular carcinoma. Can. J. Gastroenterol. Hepatol. 2017, 2017, 1548919. [PubMed]

109. Kleessen, B.; Schwarz, S.; Boehm, A.; Fuhrmann, H.; Richter, A.; Henle, T.; Krueger, M. Jerusalem artichoke and chicory inulin in bakery products affect faecal microbiota of healthy volunteers. Br. J. Nutr. 2007, 98, 540-549. [CrossRef]

110. Ramnani, P.; Gaudier, E.; Bingham, M.; Van Bruggen, P.; Tuohy, K.M.; Gibson, G.R. Prebiotic effect of fruit and vegetable shots containing Jerusalem artichoke inulin: A human intervention study. Br. J. Nutr. 2010, 104, 233-240. [CrossRef]

111. Kleessen, B.; Sykura, B.; Zunft, H.J.; Blaut, M. Effects of inulin and lactose on fecal microflora, microbial activity, and bowel habit in elderly constipated persons. Am. J. Clin. Nutr. 1997, 65, 1397-1402. [CrossRef]

112. Brighenti, F.; Casiraghi, M.C.; Canzi, E.; Ferrari, A. Effect of consumption of a ready-to-eat breakfast cereal containing inulin on the intestinal milieu and blood lipids in healthy male volunteers. Eur. J. Clin. Nutr. 1999, 53, 726-733. [CrossRef]

113. Dewulf, W.M.; Cani, P.D.; Claus, S.P.; Fuentes, S.; Puylaert, P.G.B.; Neyrinck, A.M.; Bindels, L.B.; de Vos, W.M.; Gibson, G.R.; Thissen, J.-P.; et al. Insight into the prebiotic concept: Lessons from an exploratory, double blind intervention study with inulin-type fructans in obese women. Gut 2013, 62, 1112-1121. [CrossRef]

114. Genta, S.; Cabrera, W.; Habib, N.; Pons, J.; Carillo, I.M.; Grau, A.; Sánchez, S. Yacon syrup: Beneficial effects on obesity and insulin resistance in humans. Clin. Nutr. 2009, 28, 182-187. [CrossRef]

115. Van den Abbeele, P.; Gérard, P.; Rabot, S.; Bruneau, A.; El Aidy, S.; Derrien, M.; Kleerebezem, M.; Zoetendal, E.G.; Smidt, H.; Verstraete, W.; et al. Arabinoxylans and inulin differentially modulate the mucosal and luminal gut microbiota and mucindegradation in humanized rats. Environ. Microbiol. 2011, 13, 2667-2680. [CrossRef]

116. Cuervo, A.; Valdés, L.; Salazar, N.; de los Reyes-Gavilán, C.G.; Ruas-Madiedo, P.; Gueimonde, M.; González, S. Pilot study of diet and microbiota: Interactive associations of fibers and polyphenols with human intestinal bacteria. J. Agric. Food Chem. 2014, 62, 5330-5336. [CrossRef]

117. Dethlefsen, L.; Relman, D.A. Incomplete recovery and individualized responses of the human distal gut microbiota to repeated antibiotic perturbation. Proc. Natl. Acad. Sci. USA 2011, 108, 4554-4561. [CrossRef]

118. Dethlefsen, L.; Huse, S.; Sogin, M.L.; Relman, D.A. The pervasive effects of an antibiotic on the human gut microbiota, as revealed by deep $16 \mathrm{~S}$ rRNA sequencing. PLoS Biol. 2008, 6, 2383-2400. [CrossRef]

119. Fouhy, F.; Guinane, C.M.; Hussey, S.; Wall, R.; Ryan, C.A.; Dempsey, E.M.; Murphy, B.; Ross, R.P.; Fitzgerald, G.F.; Stanton, C.; et al. High-throughput sequencing reveals the incomplete, short term, recovery of the infant gut microbiota following parental antibiotic treatment with ampicillin and gentamycin. Antimicrob. Agents Chemother. 2012, 56, 5811-5820. [CrossRef] [PubMed]

120. Tanaka, S.; Kobayashi, T.; Songjind, P.; Tateyama, A.; Tsubouchi, M.; Kiyohara, C.; Shirakawa, T.; Sonomoto, K.; Nakayama, J. Influence of antibiotic exposure in the early postnatal period on the development of intestinal microbiota. FEMS Immunol. Med. Microbiol. 2009, 56, 80-87. [CrossRef]

121. Thuny, F.; Richet, H.; Casalta, J.-P.; Angelakis, E.; Habib, G.; Raoult, D. Vancomycin treatment of infective endocarditis is linked with recently acquired obesity. PLoS ONE 2010, 5, e9074. [CrossRef]

122. Mc Farland, L.V. Antibiotic-associated diarrhea: Epidemiology, trends and treatments. Future Microbiol. 2008, 3, 563-578. [CrossRef]

123. Yu, L.C.-H.; Shih, Y.-A.; Wu, L.-L.; Lin, Y.-D.; Kuo, W.-T.; Peng., W.-H.; Lu, K.-S.; Wei, S.-C.; Turner, J.R.; Ni, Y.-H. Enteric dysbiosis promotes antibiotic resistant bacterial infection: Systemic dissemination of resistant and commensal bacteria through epithelial transcytosis. Am. J. Physiol. Gastrointest. Liver Physiol. 2014, 307, G824-G835. [CrossRef]

124. Noverr, M.C.; Falkowski, N.R.; Mc Donald, R.A.; McKenzie, A.N.; Huffnagle, G.B. Development of allergic airway disease in mice following antibiotic therapy and fungal microbiota increase: Role of host genetics, antigen and interleukin-13. Infect. Immun. 2005, 73, 30-38. [CrossRef]

125. Forslund, K.; Hildebrand, F.; Nielsen, T.; Falony, G.; Le Chatelier, E.; Sunagawa, S.; Prifti, E.; Vieira-Silva, S.; Gudmundsdottir, V.; Pedersen, H.K.; et al. Disentangling type 2 diabetes and metformin treatment signatures in the human microbiota. Nature 2015, 528, 262-266. [CrossRef]

126. Mardinoglu, A.; Boren, J.; Smith, U. Confounding effects of metformin on the human gut microbiome in type 2 diabetes. Cell Metab. 2016, 23, 1-12. [CrossRef]

127. Walsh, C.J.; Guinane, C.M.; O'Toole, P.W.; Cotter, P.D. Beneficial modulation of the gut microbiota. FEBS Lett. 2014, 588, 4120-4130. [CrossRef] 
128. Van Nood, E.; Dijkgraff, M.G.; Keller, J.J. Duodenal infusion of feces for recurrent Clostridium difficile. N. Engl. J. Med. 2013, 368, 2145. [CrossRef]

129. Ianiro, G.; Bibbò, S.; Gasbarini, A.; Cammarota, G. Therapeutic modulation of gut microbiota: Current clinical applications and future perspectives. Curr. Drug Targets 2014, 15, 762-770. [CrossRef] [PubMed]

130. Khoruts, A.; Dicksved, J.; Jansson, J.K.; Sadovsky, M.J. Changes in the composition of the human fecal microbiome after bacteriotherapy for recurrent Clostridium difficile-associated diarrhea. J. Clin. Gastroenterol. 2010, 44, 354-360. [CrossRef]

131. Hold, G.L.; Smith, M.; Grange, C.; Watt, E.R.; El-Omar, E.M.I.; Mukhopadha, I. Role of the gut microbiota in inflammatory bowel disease pathogenesis: What have we learnt in the past 10 years. World J. Gastroenterol. 2014, 20, 1192-1210. [CrossRef]

132. Rossen, N.G.; Fuentes, S.; van der Spek, M.J.; Tijssen, J.G.; Hartman, J.H.A.; Duflou, A.; Löwenberg, M.; van den Brink, G.R.; Mathus-Vliegen, E.M.H.; de Vos, W.M.; et al. Findings from a randomized controlled trial of fecal transplantation for patients with ulcerative colitis. Gastroenterology. 2015, 149, 110-118. [CrossRef]

133. Tilg, H.; Moschen, A.R. Microbiota and diabetes: An evolving relationship. Gut 2014, 63, 1513-1521. [CrossRef] [PubMed]

134. Mangiola, F.; Ianiro, G.; Franceschi, F.; Fagiouli, S.; Gasbarrini, G. Gut microbiota in autism and mood disorders. World J. Gastroenterol. 2016, 22, 361-368. [CrossRef]

135. Keshavarzian, A.; Green, S.J.; Engen, P.A.; Voigt, R.M.; Naqib, A.; Forsyth, C.B.; Mutlu, E.; Shannon, K.M. Colonic bacterial composition in Parkinson's disease. Mov. Disord. 2015, 30, 1351-1360. [CrossRef]

136. Parashar, A.; Udayabanu, M. Gut microbiota: Implications in Parkinson's disease. Parkin. Relat. Disord. 2017, 38, 177. [CrossRef]

137. Xu, H.-M.; Huang, H.-L.; Zhou, Y.L.; Zhao, H.-L.; Xu, J.; Shou, D.-W.; Liu, Y.-D.; Nie, Y.-Q. Fecal microbiota transplantation: A new therapeutic attempt from the gut to the brain. Gastroenterol. Res. Pract. 2021, 2021, 6699268. [CrossRef] [PubMed]

138. De Vos, W.M. Fame and future of faecal transplantations-Developing next generation therapies with synthetic microbiomes. Microbial. Biotechnol. 2013, 6, 316-325. [CrossRef]

139. Cani, P.; Amar, J.; Iglesias, M.A.; Poggi, M.; Knauf, C.; Bastelica, D.; Neyrinck, A.M.; Fava, F.; Tuohy, K.M.; Chabo, C.; et al. Metabolic endotoxemia initiates obesity and insulin resistance. Diabetes 2007, 56, 1761-1772. [CrossRef] [PubMed]

140. Cani, P.D.; Dlezenne, N.M. The role of the gut microbiota in energy metabolism and metabolic disease. Curr. Pharm. Des. 2009, 15, 1546-1558. [CrossRef] [PubMed]

141. Laugerette, F.; Vors, C.; Géloën, A.; Chauvin, M.-G.; Soulage, C.; Lambert-Porcheron, S.; Peretti, N.; Alligier, M.; Burcelin, R.; Laville, M.; et al. Emulsified lipids increase endotoxemia: A possible role in early postprandial low-grade inflammation. J. Nutr. Biochem. 2011, 22, 53-59. [CrossRef]

142. Ghanim, H.; Abuaysheh, S.; Sia, C.L.; Korzeniewski, K.; Chaudhuri, A.; Fernandez-Real, J.M.; Dandona, P. Increase in plasma endotoxin concentrations and the expression of toll-like receptors and suppressor of cytokine signaling-3 in mononuclear cells after a high-fat, high-carbohydrate meal: Implications for insulin resistance. Diabet. Care 2009, 32, 2281-2287. [CrossRef] [PubMed]

143. Turnbaugh, P.J.; Hamady, M.; Yatsunenko, T.; Cantarel, B.L.; Duncan, A.; Ley, R.E.; Sogin, M.L.; Jones, W.J.; Roe, B.A.; Affourtit, J.P.; et al. A core guts microbiome in obese and lean twins. Nature 2009, 457, 480-484. [CrossRef]

144. Cani, P.D.; Delzenne, N.M. Gut microflora as a target for energy and metabolic homeostasis. Curr. Opin. Clin. Nutr. Metab. 2007, 10, 729-734. [CrossRef]

145. Carding, S.; Verbeke, K.; Vipond, D.T.; Corfe, B.M.; Owen, L.J. Dysbiosis of the gut microbiota in disease. Microb. Ecol. Health Dis. 2015, 26, 26191. [CrossRef] [PubMed]

146. Lee, E.S.; Song, E.J.; Nam, Y.D. Dysbiosis of gut microbiome and its impact on epigenetic regulation. J. Clin. Epigenet. 2017, 3, 14.

147. Singh, R.; Zogg, H.; Wei, L.; Bartlett, A.; Ghoshal, U.C.; Rajender, S.; Ro, S. Gut microbial dysbiosis in the pathogenesis of gastrointestinal dysmotility and metabolic disorders. J. Neurogastroenterol. Motil. 2021, 27, 19-34. [CrossRef] [PubMed]

148. Zhang, X.; Shi, L.; Sun, T.; Guo, K.; Geng, S. Dysbiosis of gut microbiota and its correlation with dysregulation of cytokines in psoriasis patients. BMC Microbiol. 2021, 21, 78. [CrossRef] [PubMed]

149. Belizário, J.E.; Faintuch, J.; Garay-Malpartida, M. Gut microbiome dysbiosis and immunometabolism: New frontiers for treatment of metabolic diseases. Mediat. Inflamm. 2018, 2018, 2037838. [CrossRef] [PubMed]

150. Wang, L.; Wan, Y.-J.Y. The role of gut microbiota in liver disease development and treatment. Liver Res. 2019, 3, 3-18. [CrossRef] [PubMed]

151. Liguori, G.; Lamas, B.; Richard, M.L.; Brandi, G.; da Costa, G.; Hoffmann, T.W.; Di Simone, M.P.; Calabrese, C.; Poggioli, G.; Langella, P.; et al. Fungal dysbiosis in mucos-associated microbiota of Crohn's disease patients. J. Crohn's Collit. 2016, 10, $296-305$. [CrossRef] [PubMed]

152. Wang, M.; Zhao, J.; Zhang, L.; Wei, F.; Lian, Y.; Wu, Y.; Gong, Z.; Zhang, S.; Zhou, J.; Cao, K.; et al. Role of tumor microenvironment in tumorigenesis. J. Cancer 2017, 8, 761-773. [CrossRef]

153. Gabaldón, T. Roles of human microbiome in cancer. HepatoBiliary Surg. Nutr. 2021, 10, 558-560. [CrossRef]

154. Song, P.; Wang, Q.-B.; Liang, B.; Jiang, S.-J. Advances in research on the relationship between the gut microbiome and cancer. Eur. Rev. Med. Pharmacol. Sci. 2021, 25, 5104-5112.

155. Wang, F.; Meng, W.; Wang, B.; Qiao, L. Helicobacter pylori-induced gastric inflammation and gastric cancer. Cancer Lett. 2014, 345, 196-202. [CrossRef] [PubMed]

156. Di Domenico, E.G.; Cavallo, I.; Pontone, M.; Toma, L.; Ensoli, F. Biofilm producing Salmonella typhi: Colonization and development of gallbladder cancer. Int. J. Mol. Sci. 2017, 18, 1887. [CrossRef] 
157. Elinav, E.; Nowarski, R.; Thaiss, C.A.; Hu, B.; Jin, C.; Flavell, R.A. Inflammation-induced cancer: Crosstalk between tumours, immune cells and microorganisms. Nat. Rev. Cancer 2013, 13, 759-771. [CrossRef]

158. Dzutsev, A.; Goldschmid, R.S.; Viaud, S.; Zitvogel, L.; Trincheri, G. The role of the microbiota in inflammation, carcinogenesis, and cancer therapy. Eur. J. Immunol. 2015, 45, 17-31. [CrossRef]

159. Purcell, R.V.; Pearson, J.; Aitchison, A.; Dixon, L.; Frizelle, F.A.; Keenan, J.L. Colonization with enterotoxigenic Bacteroides fragilis is associated with early-stage colorectal neoplasia. PLoS ONE 2017, 12, e0171602. [CrossRef] [PubMed]

160. Mangerich, A.; Knutson, C.G.; Parry, N.M.; Muthupalani, S.; Ye, W.; Prestwich, E.; Cui, L.; McFaline, J.L.; Mobley, M.; Ge, Z.; et al. Infection-induced colitis in mice causes dynamic and tissue-specific changes in stress response and DNA damage leading to colon cancer. Proc. Natl. Acad. Sci. USA 2012, 109, E1820-E1829. [CrossRef] [PubMed]

161. Gur, C.; Ibrahim, Y.; Isaacson, B.; Yamin, R.; Abed, J.; Gamliel, M.; Enk, J.; Bar-On, Y.; Stanietsky-Kaynan, N.; Coppenhagen-Glazer, S.; et al. Binding of the Fap2 protein of Fusobacterium nucleatum to human inhibitory receptor TIGIT protects tumors from immune cell attack. Immunity 2015, 42, 344-355. [CrossRef]

162. Tomkovich, S.; Yang, Y.; Winglee, K.; Gauthier, J.; Mühlbauer, M.; Sun, X.; Mohamadzadeh, M.; Liu, X.; Martin, P.; Wang, G.P.; et al. Locoregional effects of microbiota in a preclinical model of colon carcinogenesis. Cancer Res. 2017, 77, 2620-2632. [CrossRef] [PubMed]

163. Garrett, W.S. The gut microbiota and colon cancer. Science 2019, 364, 1133-1135. [CrossRef]

164. Yu, J.; Chen, Y.; Fu, X.; Zhou, X.; Peng, Y.; Shi, L.; Chen, T.; Wu, Y. Invasive Fusobacterium nucleatum may play a role in the carcinogenesis of proximal colon cancer through the serrated neoplasia pathway. Int. J. Cancer 2016, 139, 1318-1326. [CrossRef]

165. Yang, Y.; Jobin, C. Far reach of Fusobacterium nucleatum in cancer metastasis. Gut 2021, 70, 1427-1429. [CrossRef] [PubMed]

166. Helmink, B.A.; Khan, M.A.W.; Hermann, A.; Gopalakrishnan, V.; Wargo, J.A. The microbiome, cancer, and cancer therapy. Natur. Med. 2019, 25, 377-388. [CrossRef]

167. Vivarelli, S.; Salemi, R.; Candido, S.; Falzone, L.; Santagati, M.; Stefani, S.; Torino, F.; Banna, G.L.; Tonini, G.; Libra, M. Gut microbiota and cancer: From pathogenesis to therapy. Cancers 2019, 11, 38. [CrossRef]

168. Dzutsev, A.; Badger, J.H.; Perez-Chanona, E.; Roy, S.; Salcedo, R.; Smith, C.K.; Trinchieri, G. Microbes and cancer. Ann. Rev. Immunol. 2017, 35, 199-228. [CrossRef] [PubMed]

169. Bray, F.; Ferlay, J.; Soerjomataram, I.; Siegel, R.L.; Torre, L.A.; Jemal, A. Global cancer statistics 2018: GLOBOCAN estimates of incidence and mortality worldwide for 36 cancers in 185 countries. CA Cancer J. Clin. 2018, 68, 394-424. [CrossRef] [PubMed]

170. Verma, D.; Garg, P.K.; Dubey, A.K. Insight into the human oral microbiome. Arch. Microbiol. 2018, 200, 525-540. [CrossRef]

171. Zhao, H.; Chu, M.; Huang, Z.; Yang, X.; Ran, S.; Hu, B.; Zhang, C.; Liang, J. Variations in oral microbiota associated with oral cancer. Sci. Rep. 2017, 7, 11773. [CrossRef]

172. Deo, P.N.; Deshmukh, R. Oral microbiome: Unveiling the fundamentals. J. Oral Maxifac. Pathol. 2019, 23, $122-128$.

173. Sharma, N.; Bhatia, S.; Sodhi, A.S.; Batra, N. Oral microbiome and health. AIMS Microbiol. 2018, 4, 42-66. [CrossRef] [PubMed]

174. Morgan, X.C.; Huttenhower, C. Human microbiome analysis. PLoS Comput. Biol. 2012, 8, e1002808.

175. Kakabadze, M.Z.; Paresishvili, T.; Karalashvili, L.; Chakhunashvili, D.; Kakabadze, Z. Oral microbiota and oral cancer: Review. Oncol. Rev. 2020, 14, 129-134. [CrossRef] [PubMed]

176. Perera, M.; Al-Hebshi, N.N.; Perera, I.; Ipe, D.; Ulett, G.C.; Speicher, D.J.; Chen, T.; Johnson, N.W. Inflammatory bacteriome and oral squamous cell carcinoma. J. Dent. Res. 2018, 97, 725-732. [CrossRef] [PubMed]

177. Zhang, L.; Liu, Y.; Zheng, H.J.; Zhang, C.P. The oral microbiota may have influence on oral cancer. Front. Cell Front. Microbiol. 2020, 9, 476. [CrossRef]

178. Al-Hebshi, N.N.; Borgnakke, W.S.; Johnson, N.W. The microbiome of oral squamous cell carcinoma: A functional perspective. Curr. Oral Health 2019, 6, 145-160. [CrossRef]

179. Lizana, C.; Valenzuela, O.; Mejia, M. Identification of the salivary microbiota of patients with oral cancer in Antofagosta-Chile by molecular diagnosis of the 16S rRNA gene. Int. J. Odontostomat. 2018, 12, 87-92. [CrossRef]

180. Robayo, D.A.G.; Hernandez, R.F.; Eviera, A.T.; Kandaurova, L.; Juarez, C.L.; Juarez, V.; Cid-Arregui, A. Oral microbiota associated with oral and gastroenteric cancer. Open Microb. J. 2020, 14, 1-7. [CrossRef]

181. Tuominen, H.; Rautava, J. Oral microbiota and cancer development. Pathobiology 2021, 88, 116-126. [CrossRef] [PubMed]

182. Irfan, M.; Delgado, R.Z.R.; Frias-Lopez, J. The oral microbiome and cancer. Front. Immunol. 2020, 11, 591088. [CrossRef] [PubMed]

183. Sun, J.; Tang, Q.; Yu, S.; Xie, M.; Xie, Y.; Chen, G.; Chen, L. Role of the oral microbiota in cancer evolution and progression. Cancer Med. 2020, 9, 6306-6321. [CrossRef] [PubMed]

184. Oliva, M.; Schneeberg, P.H.H.; Rey, V.; Cho, M.; Taylor, R.; Hansen, A.R.; Taylor, K.; Hosni, A.; Bayley, A.; Hope, A.J.; et al. Transitions in oral and gut microbiome of HPV+ oropharyngeal squamous cell carcinoma following definitive chemoradiotherapy (ROMA LA-OPSCC study). Br. J. Cancer 2021, 124, 1543-1551. [CrossRef]

185. Le Bars, P.; Matamoros, S.; Montassier, E.; Le Vacon, F.; Potel, G.; Soueidan, A.; Jordana, F.; de la Cochètiere, M.-F. The oral cavity microbiota: Between health, oral disease, and cancers of the aerodigestive tract. Can. J. Microbiol. 2017, 63, 475-492. [CrossRef] [PubMed]

186. Karpiński, T.M. Role of oral microbiota in cancer development. Microorganisms 2019, 7, 20. [CrossRef]

187. Li, Y.; Tan, X.; Zhao, X.; Xu, Z.; Dai, W.; Duan, W.; Huang, S.; Zhang, E.; Liu, J.; Zhang, S.; et al. Composition and function of oral microbiota between gingival squamous cell carcinoma and periodontitis. Oral Oncol. 2020, 107, 104710. [CrossRef] 
188. Zhang, Y.; Wang, X.; Li, H.; Ni, C.; Du, Z.; Yan, F. Human oral microbiota and its modulation for oral health. Biomed. Pharmacother. 2018, 99, 883-893. [CrossRef] [PubMed]

189. Zhang, W.-L.; Wang, S.-S.; Wang, H.-F.; Tang, Y.-J.; Tang, Y.-L. Who is who in oral cancer? Exptl. Cell Res. 2019, $384,111634$. [CrossRef] [PubMed]

190. Szkaradkiewicz, A.K.; Karpiński, T.M. Microbiology of chronic periodontitis. J. Biol. Earth Sci. 2013, 3, M14-M20.

191. Yang, S.-F.; Huang, H.-D.; Fan, W.-L.; Jong, Y.-J.; Chen, M.-K.; Huang., C.-N.; Chuang, C.-Y.; Kuo., Y.-L.; Chung, W.-H.; Su., S.-C. Compositional and functional variations of oral microbiota associated with the mutational changes in oral cancer. Oral Oncol. 2018, 77, 1-8. [CrossRef] [PubMed]

192. Sun, Y.; Liu, N.; Guan, X.; Wu, H.; Sun, Z.; Zeng, H. Immunosuppression induced by chronic inflammation and the progression to oral squamous cell carcinoma. Mediat. Inflamm. 2016, 2016, 5715719. [CrossRef] [PubMed]

193. Kuboniwa, M.; Hasegawa, Y.; Mao, S.; Shizukuishi, S.; Amano, A.; Lamont, R.J.; Yilmaz, O.P. gingivalis accelerates gingival epithelial cell progression through the cell cycle. Microb. Infect. 2008, 10, 122-128. [CrossRef]

194. Mao, S.; Park, Y.; Hasegawa, Y.; Tribble, G.D.; James, C.E.; Handfield, M.; Stavropoulos, M.F.; Yilmaz, O.; Lamont, R.J. Intrinsic apoptotic pathways of gingival epithelial cells modulated by Porphyromonas gingivalis. Cell Microbiol. 2007, 9, $1997-2007$. [CrossRef] [PubMed]

195. Healy, C.M.; Morgan, G.P. The microbiome and oral cancer: More questions than answers. Oral Oncol. 2019, 89, 30-33. [CrossRef]

196. Alnuaimi, A.D.; Wiesenfeld, D.; O’Brien-Simpson, N.M.; Reynolds, E.C.; McCullough, M.J. Oral Candida colonization in oral cancer patients and its relationship with traditional risk factor of oral cancer: A matched case control study. Oral Oncol. 2015, 51, 139-145. [CrossRef] [PubMed]

197. Abdulrahum, M.H.; Mc Manus, B.A.; Flint, S.R.; Coleman, D.C. Genotyping Candida albicans from Candida leukoplakia and non-Candida leukoplakia shows no enrichment of multilocus sequence typing clades but enrichment of $A B C$ genotype $C$ in Candida leukoplakia. PLoS ONE 2013, 8, e73738. [CrossRef]

198. Gainza-Ciraqui, M.L.; Nieminen, M.T.; Novak Frazer, L.; Aguirre-Urizar, J.M.; Moragues, M.D.; Rautemaa, R. Production of carcinogenic acetylaldehyde by Candida albicans from patients with potentially malignant oral mucosal disorders. J. Oral. Pathol. Med. 2013, 42, 243-249. [CrossRef] [PubMed]

199. O'Grady, J.F.; Reade, P.C. Candida albicans as a promoter of oral mucosal neoplasia. Carcinogenesis 1992, 13, 783-786. [CrossRef] [PubMed]

200. Amer, A.; Galvin, S.; Healy, C.M.; Magan, G.P. Microbiome of potentially malignant oral leukoplakia exhibits enrichment for Fusobacterium, Leptotricha, Campylobacter and Rothia species. Front. Microbiol. 2017, 8, 2391. [CrossRef] [PubMed]

201. Ferlay, J.; Soerjomataram, L.; Dikshit, R.; Eser, S.; Mathers, C.; Rebelo, M.; Parkin, D.M.; Forman, D.; Bray, F. Cancer incidence and mortality worldwide; sources, methods and major patterns in GLOBOCAN 2012. Int. J. Cancer 2015, 136, E359-E386. [CrossRef]

202. Wang, Q.; Rao, Y.; Guo, X.; Liu, N.; Liu, S.; Wen, P.; Li, S.; Li, Y. Oral microbiome in patients with oesophageal squamous cell carcinoma. Sci. Rep. 2019, 9, 19055. [CrossRef]

203. Gupta, E.; Kumar, N. Worldwide incidence, mortality and time trends for cancer of the oesophagus. Eur. J. Cancer Prev. 2017, 26, 107-118. [CrossRef]

204. Rustgi, A.K.; El-Serag, H.B. Esophageal carcinoma. N. Engl. J. Med. 2014, 371, 2499-2509. [CrossRef] [PubMed]

205. Hvid-Jensen, F.; Pedersen, L.; Drewes, A.M.; Sørensen, H.T.; Funch-Jensen, P. Incidence of adenocarcinoma among patients with Barrett's esophagus. N. Engl. J. Med. 2011, 365, 1375-1383. [CrossRef] [PubMed]

206. Rubinstein, J.H.; Shahen, N.J. Epidemiology, diagnosis, and management of esophageal adrenocarcinoma. Gastroenterology 2015, 149, 302-317. [CrossRef]

207. May, M.; Abrams, J.A. Emerging insights into the esophageal microbiome. Curr. Treat. Options Gastroenterol. 2018, 16, 72-85. [CrossRef]

208. Corning, B.; Copland, A.P.; Frye, J.W. The esophageal microbiome in health and disease. Curr. Gastroenterol. Rep. 2018, 20, 39. [CrossRef]

209. Mannell, A.; Plant, M.; Frolich, J. The microflora of the oesophagus. Ann. R. Coll. Surg. Engl. 1983, 65, $152-154$.

210. Narikiyo, M.; Tanabe, C.; Yamada, Y.; Igaki, H.; Tachimori, Y.; Kato, H.; Muto, M.; Montesano, R.; Sakamoto, H.; Nakajima, Y.; et al. Frequent and potential infection of Treponema denticola, Streptococcus mitis, and Streptococcus anginosus in esophageal cancers. Cancer Sci. 2004, 95, 569-574. [CrossRef] [PubMed]

211. Elliott, D.R.F.; Walker, A.W.; O’Donovan, M.; Parkhill, J.; Fitzgerald, R.C. A non-endoscopic device to sample the esophageal microbiota: A case-control study. Lancet Gastroenterol. Hepatol. 2017, 2, 32-42. [CrossRef]

212. Peters, B.A.; Wu, J.; Pei, Z.; Yang, L.; Purdue, M.P.; Freedman, N.D.; Jacobs, E.J.; Gapstur, S.M.; Hayes, R.B.; Ahn, J. Oral microbiome composition reflects prospective risk for esophageal cancers. Cancer Res. 2017, 77, 6777-6787. [CrossRef]

213. Gall, A.; Fero, J.; McCoy, C.; Claywell, B.C.; Sanchez, C.A.; Blount, P.L.; Li, X.; Vaughan, T.L.; Matsen, F.A.; Reid, B.J.; et al. Bacterial composition of the human upper gastrointestinal tract microbiome is dynamic and associated with genomic instability in a Barrett's esophagus cohort. PLoS ONE 2015, 10, e0129055. [CrossRef]

214. Snider, E.J.; Freedberg, D.E.; Abrams, J.A. Potential role of the microbiome in Barrett's esophagus and esophageal adenocarcinoma. Dig. Dis. Sci. 2016, 61, 2217-2225. [CrossRef] [PubMed] 
215. Yu, G.; Gail, M.H.; Shi, J.; Klepac-Ceraj, V.; Paster, B.J.; Dye, B.A.; Wang, G.-Q.; Wei, W.-Q.; Fan, J.-H.; Qiao., Y.-L.; et al. Association between upper digestive tract microbiota and cancer-predisposing states in the esophagus and stomach. Cancer Epidemiol. Biomark. Prev. 2014, 23, 735-741. [CrossRef] [PubMed]

216. Gao, S.; Li, S.; Ma, Z.; Liang, S.; Shan, T.; Zhang, M.; Zhu, X.; Zhang, P.; Liu, G.; Zhou, F.; et al. Presence of Porphyromonas gingivalis is esophagus and its association with the clinicopathological characteristics and survival in patients with esophageal cancer. Infect. Agent Cancer 2016, 11, 3. [CrossRef]

217. Chen, X.; Winckler, B.; Lu, M.; Cheng, H.; Yuan, Z.; Yang, Y.; Jin, L.; Ye, W. Oral microbiota and risk for esophageal squamous cell carcinoma in a high-risk area of China. PLoS ONE 2015, 10, e0143603. [CrossRef] [PubMed]

218. Yamamura, K.; Baba, Y.; Nakagawa, S.; Mima, K.; Miyake, K.; Nakamura, K.; Sawayama, H.; Kinoshita, K.; Ishimoto, T.; Iwatsuki, M.; et al. Human microbiome Fusobacterium nucleatum in esophageal cancer tissue is associated with prognosis. Clin. Cancer Res. 2016, 22, 5574-5581. [CrossRef]

219. Polakovicova, J.; Jerez, S.; Wichmann, I.A.; Sandoval-Borquez, A.; Carrasco-Véliz, N.; Corvalán, A.H. Role of microRNA and exosomes in Helicobacter pylori and Epstein-Barr virus associated gastric cancers. Front. Microbiol. 2018, 9, 636. [CrossRef]

220. Schulz, C.; Schütte, K.; Mayerle, J.; Malfertheiner, P. The role of the gastric bacterial microbiome in gastric cancer: Helicobacter pylori and beyond. Ther. Adv. Gastroenterol. 2019, 12,1-11. [CrossRef] [PubMed]

221. Peek, R.M., Jr.; Crabtree, J.E. Helicobacter infection and gastric neoplasia. J. Pathol. 2006, 208, 233-248. [CrossRef] [PubMed]

222. Shah, M.A. Gastric cancer: The gastric microbiota-Bacterial diversity and implications. Nat. Rev. Gastroenterol. Hepatol. 2017, 14, 692-693. [CrossRef] [PubMed]

223. Nardone, G.; Compare, D. The human gastric microbiota: Is it time to rethink the pathogenesis of stomach diseases? Un. Eur. Gastroenterol. J. 2015, 3, 255-260. [CrossRef] [PubMed]

224. Blaser, M.J.; Atherton, J.C. Helicobacter pylori persistence: Biology and disease. J. Clin. Investig. 2004, 113, 321-333. [CrossRef]

225. Leach, S.A.; Thompson, M.; Hill, M. Bacterially catalyzed N-nitrosation reactions and their relative importance in the human stomach. Carcinogenesis 1987, 8, 1907-1912. [CrossRef]

226. Gantuya, B.; El-Serag, H.B.; Matsumoto, T.; Matsumoto, A.; Ajami, N.J.; Oyuntsetseg, K.; Azzaya, D.; Uchida, T.; Yamaoka, Y. Gastric microbiota in Helicobacter pylori-negative and -positive gastritis among high incidence of gastric cancer area. Cancers 2019, 11, 504. [CrossRef]

227. Erawijantari, P.P.; Mizutani, S.; Shiroma, H.; Shiba, S.; Nakajima, T.; Sakamoto, T.; Saito, Y.; Fukuda, S.; Yachida, S.; Yamada, T. Influence of gastrectomy for gastric cancer treatment on fecal microbiome and metabolome profiles. Gut 2020, 69, 1404-1415. [CrossRef]

228. Chen, X.-H.; Wang, A.; Chu, A.-N.; Gong, Y.-H.; Yuan, Y. Mucosa associated microbiota in gastric cancer tissues compared with non-cancer tissues. Front. Microbiol. 2019, 10, 1261. [CrossRef]

229. Jo, H.J.; Kim, J.; Kim, N.; Park, J.H.; Nam, R.H.; Seok, Y.-J.; Kim, Y.-R.; Kim, J.S.; Kim, J.M.; Kim, J.M.; et al. Analysis of gastric microbiota by pyrosequencing: Minor role of bacteria other than Helicobacter pylori in the gastric carcinogenesis. Helicobacter 2016, 21, 364-374. [CrossRef]

230. Ferreira, R.M.; Pereira-Marques, J.; Pinto-Ribeino, I.; Costa, J.L.; Carneiro, F.; Machado, J.C.; Figueiredo, C. Gastric microbial community profiling reveals a dysbiotic cancer-associated microbiota. Gut 2018, 67, 226-236. [CrossRef]

231. Hu, Y.-L.; Pang, W.; Huang, Y.; Zhang, Y.; Zhang, C.-J. The gastric microbiome is perturbed in advanced gastric adenocarcinoma identified through shotgun metagenomics. Front. Cell Infect. Microbiol. 2018, 8, 433. [CrossRef]

232. Liu, X.; Nie, W.; Liang, J.; Li, Y. Interaction of Helicobacter pylori with other microbiota species in the development of gastric cancer. Arch. Clin. Microbiol. 2017, 8, 37. [CrossRef]

233. Wang, L.-L.; Liu, J.-X.; Yu, X.-J.; Si, J.-L.; Zhai, Y.-X.; Dong, Q.-J. Microbial community reshaped in gastric cancer. Eur. Rev. Med. Pharmacol. Sci. 2018, 22, 7257-7264.

234. Yu, G.; Torres, J.; Hu, N.; Medrano-Guzman, R.; Herrera-Goepfert, R.; Humphrys, M.S.; Wang, L.; Wang, C.; Ding, T.; Ravel, J.; et al. Molecular characterization of the human stomach microbiota in gastric cancer patients. Front. Cell Infect. Microbiol. 2017, 7, 302. [CrossRef] [PubMed]

235. Coker, O.O.; Dai, Z.; Nie, Y.; Zhao, G.; Cao, L.; Nakatsu, G.; Wu, W.K.; Wong, S.H.; Chen, Z.; Sung, J.J.Y.; et al. Mucosal microbiome dysbiosis in gastric carcinogenesis. Gut 2018, 67, 1024-1032. [CrossRef] [PubMed]

236. Davis, C.D.; Milner, J.A. Gastrointestinal microflora, food components and colon cancer prevention. J. Nutr. Biochem. 2009, 20, 743-752. [CrossRef] [PubMed]

237. Sobhani, I.; Bergsten, E.; Couffin, S.; Amiot, A.; Nebbad, B.; Barau, C.; de'Angelis, N.; Rabot, S.; Canoui-Poitrine, F.; Mestivier, D.; et al. Colorectal cancer-associated microbiota contributes to oncogenic epigenetic signatures. Proc. Natl. Acad. Sci. USA 2019, 116, 24285-24295. [CrossRef]

238. Sobhani, I.; Tap, J.; Roudot-Thoraval, F.; Roperch, J.P.; Letulle, S.; Langella, P.; Corthier, G.; Van Nhieu, J.T.; Furet, J.P. Microbial dysbiosis in colorectal cancer (CRC) patients. PLoS ONE 2011, 6, e16393. [CrossRef]

239. Sanapareddy, N.; Legge, R.M.; Javov, B.; McCoy, A.; Burcal, L.; Araujo-Perez, F.; Randall, T.A.; Galanko, J.; Benson, A.; Sandler, R.S.; et al. Increased rectal microbial richness is associated with the presence of colorectal adenomas in humans. ISME J. 2012, 6, 1858-1868. [CrossRef] 
240. Thomas, A.M.; Manghi, P.; Asnicar, F.; Pasolli, E.; Armanini, F.; Zolfo, M.; Beghini, F.; Manara, S.; Karcher, N.; Pozzi, C.; et al. Metagenomic analysis of colorectal cancer datasets identifies cross-cohort microbial diagnostic signatures and link with choline degradation. Nat. Med. 2019, 25, 667-678. [CrossRef]

241. Wirbel, J.; Pyl, P.T.; Kartal, E.; Zych, K.; Kashani, A.; Milanese, A.; Fleck, J.S.; Voigt, A.Y.; Palleja, A.; Ponnudurai, R.; et al. Meta-analysis of fecal metagenomes reveals global microbial signatures that are specific for colorectal cancer. Nat. Med. 2019, 25, 679-689. [CrossRef] [PubMed]

242. Wong, S.H.; Zhao, L.; Zhang, X.; Nakatsu, G.; Han, J.; Xu, W.; Xiao, X.; Kwong, T.N.Y.; Tsoi, H.; Wu, W.K.K.; et al. Gavage of fecal samples from patients with colorectal cancer promotes intestinal carcinogenesis in germ-free and conventional mice. Gastroenterology 2017, 153, 1621-1633. [CrossRef]

243. Gagnière, J.; Raisch, J.; Veziant, J.; Barnich, N.; Bonnet, R.; Buc, E.; Bringer, M.-A.; Pezet, D.; Bonnet, M. Gut microbiota imbalance and colorectal cancer. World J. Gastroenterol. 2016, 22, 501-518. [CrossRef]

244. Saus, E.; Iraola-Guzmán, S.; Willis, J.R.; Brunet-Vega, A.; Gabaldón, T. Microbiome and colorectal cancer. Roles in carcinogenesis and clinical potential. Mol. Apects. Med. 2019, 69, 93-106. [CrossRef]

245. Yu, J.; Feng, Q.; Wong, S.H.; Zhang, D.; Liang, Q.Y.; Qin, Y.; Tang, L.; Zhao, H.; Stenvang, J.; Li, Y.; et al. Metagenomic analysis of fecal microbiome as a tool towards targeted non-invasive biomarkers for colorectal cancer. Gut 2017, 66, 70-78. [CrossRef]

246. Moore, W.E.; Moore, L.H. Intestinal floras of populations that have a high risk of colon cancer. Appl. Environ. Microbiol. 1995, 61, 3202-3207. [CrossRef]

247. O'Keefe, S.J.; Chung, D.; Mahmoud, N.; Sepulveda, A.R.; Manafe, M.; Arch, J.; Adada, H.; van der Merwe, T. Why do African Americans get more colon cancer than Native Africans? J. Nutr. 2007, 137, 175S-182S. [CrossRef]

248. Feng, Q.; Liang, S.; Jia, H.; Stadlmayr, A.; Tang, L.; Lan, Z.; Zhang, D.; Xia, H.; Xu, X.; Jie, Z.; et al. Gut microbiome development along the colorectal adenoma-carcinoma sequence. Nat. Commun. 2015, 6, 6528. [CrossRef]

249. Marchesi, J.R.; Dutilh, B.E.; Hall, N.; Peters, W.H.M.; Roelofs, R.; Boleij, A.; Tjalsma, H. Towards the human colorectal cancer microbiome. PLOS ONE 2011, 6, e20447. [CrossRef]

250. Kostic, A.D.; Gevers, D.; Pedamalu, C.S.; Michaud, M.; Duke, F.; Earl, A.M.; Ojesina, A.I.; Jung, J.; Bass, A.J.; Tabernero, J.; et al. Genomic analysis identifies association of Fusobacterium with colorectal carcinoma. Genome 2012, 22, 292-298. [CrossRef] [PubMed]

251. Rubinstein, M.R.; Wang, X.; Liu, W.; Hao, Y.; Cai, G.; Han, Y.W. Fusobacterium nucleatum promotes colorectal carcinogenesis by modulating E-cadherin/ $\beta$-catenin signaling via its FadA adhesion. Cell Host Microb. 2013, 14, 195-206. [CrossRef]

252. Blake, S.J.; Dougall, W.C.; Miles, J.J.; Teng, M.W.L.; Smyth, M.J. Molecular pathways: Targeting CD96 and TIGIT for cancer immunotherapy. Clin. Cancer Res. 2016, 22, 5183-5188. [CrossRef] [PubMed]

253. Mima, K.; Cao, Y.; Chan, A.T.; Zhi Rong Qian, Z.R.; Nowak, J.A.; Masugi, Y.; Shi, Y.; Song, M.; da Silva, A.; Gu, M.; et al. Fusobacterium nucelatum in colorectal carcinoma tissues according to tumor location. Clin. Transl. Gastroenterol. 2016, 7, e200. [CrossRef]

254. Yan, X.; Liu, L.; Li, X.; Qin, H.; Sun, Z. Clinical significance of Fusobacterium nucleatum, epithelial-mesenchymal transition, and cancer stem cell markers in stage III/IV colorectal cancer patients. OncoTarg. Therap. 2017, 10, 5031-5046. [CrossRef] [PubMed]

255. Dejea, C.M.; Fathi, P.; Craig, J.M.; Boleij, A.; Taddese, R.; Geis, A.L.; Wu, X.; DeStefano Shields, C.E. Hechenbleikner, E.M.; Huso, D.L.; Anders, R.A.; et al. Patients with familial adenomatous polyposis harber colonic biofilms containing tumorigenic bacteria. Science 2018, 359, 592-597. [CrossRef]

256. Goodwin, A.C.; Shields, C.E.D.; Wu, S.; Huso, D.L.; Wu, X.Q.; Murray-Stewart, T.R.; Hacker-Prietz, A.; Rabizadeh, S.; Woster, P.W.; Sears, C.L.; et al. Polyamine catabolism contributes to enterogenic Bacteroides fragilis-induced colon tumorigenesis. Proc. Natl. Acad. Sci. USA 2011, 108, 15354-15359. [CrossRef]

257. Wu, S.; Rhe, K.-J.; Albesiano, E.; Rabizadeh, S.; Wu, X.; Yen, H.-R.; Huso, D.L.; Brancati, F.L.; Wick, E.; McAllister, F.; et al. A human colonic commensal promotes colon tumorigenesis via activation of T helper type $17 \mathrm{~T}$ cell responses. Nat. Med. 2009, 15, 1016-1022. [CrossRef]

258. Geis, A.L.; Fan, H.; Wu, X.; Wu, S.; Huso, D.L.; Wolfe, J.L.; Sears, C.L.; Pardoll, D.M.; Franck Housseau, F. Regulatory T cell response to enterogenic Bacteroides fragilis colonization triggers IL-17-dependent colon carcinogenesis. Cancer Discov. 2015, 5, 1098-1109. [CrossRef]

259. Arthur, J.C.; Perez-Charona, E.; Mühlbauer, M.; Tomkovich, S.; Uronis, J.M.; Fan, T.-J.; Campbell, B.J.; Abujamel, T.; Dogan, B.; Rogers, A.B.; et al. Intestinal inflammation targets cancer-induced activity of the microbiota. Science 2012, 338, 120-123. [CrossRef]

260. Wilson, M.R.; Jiang, Y.; Villalta, P.W.; Stornetta, A.; Boudreau, P.D.; Carrá, A.; Brennan, C.A.; Chun, E.; Ngo, L.; Samson, L.D.; et al. The human gut bacterial genotoxin colibactin alkylates DNA. Science 2019, 363, eaar7785. [CrossRef]

261. Cougnoux, A.; Dalmasso, G.; Martinez, R.; Buc, E.; Delmas, J.; Gibold, L.; Sauvanet, P.; Darcha, C.; Déchelotte, P.; Bonnet, M.; et al. Bacterial genotoxin colibactin promotes colon tumor growth by inducing a senescence-associated secretory phenotype. Gut 2014, 63, 1932-1942. [CrossRef]

262. Siegel, R.L.; Miller, K.D.; Jemal, A. Cancer statistics, 2019. CA Cancer J. Clin. 2019, 69, 7-34. [CrossRef] [PubMed]

263. Groot, V.P.; Wolfgang, C.L.; He, J. ASO author reflections: Do distinct patterns of recurrence impact the prognosis of patients with resected pancreatic ductal adenocarcinoma. Ann. Surg. Oncol. 2018, 25, 806-807. [CrossRef] [PubMed]

264. Michaud, D.S.; Izard, J. Microbiota, oral microbiome, and pancreatic cancer. Cancer J. 2014, 20, 203-206. [CrossRef] 
265. Yu, Q.; Jobin, C.; Thomas, R.M. Implications of the microbiome in the development and treatment of pancreatic cancer: Thinking outside of the box by looking inside the gut. Neoplasia 2021, 23, 246-256. [CrossRef]

266. Vitiello, G.A.; Cohen, D.J.; Miller, G. Harnessing the microbiome for pancreatic cancer immunotherapy. Trends Cancer 2019, 5, 670-676. [CrossRef]

267. Maekawa, T.; Fukaya, R.; Takamatsu, S.; Itoyama, S.; Fukuoka, T.; Yamada, M.; Hata, T.; Nagaoka, S.; Kawamoto, K.; Eguchi, H.; et al. Possible involvement of Enterococcus infection in the pathogenesis of chronic pancreatitis and cancer. Biochem. Biophys. Res. Commun. 2018, 506, 962-969. [CrossRef]

268. Pushalkar, S.; Hundeyin, M.; Daley, D.; Zambirinis, C.P.; Kurz, E.; Mishra, A.; Mohan, N.; Aykut, B.; Usyk, M.; Torres, L.E.; et al. The pancreatic cancer microbiome promotes oncogenesis by induction of innate and adaptive immune suppression. Cancer Discov. 2018, 8, 403-416. [CrossRef]

269. Dickson, I. Microbiome promotes pancreatic cancer. Nat. Rev. Gastroenterol. Hepatol. 2018, 15, 328. [CrossRef] [PubMed]

270. Mitsuhashi, K.; Nosho, K.; Sukawa, Y.; Matsunaga, Y.; Ito, M.; Kurihara, H.; Kanno, S.; Igarashi, H.; Naito, T.; Adachi, Y.; et al. Association of Fusobacterium species in pancreatic cancer tissues with molecular features and prognosis. Oncotarget 2015, 6, 7209-7222. [CrossRef]

271. Geller, L.T.; Barzily-Rokni, M.; Danino, T.; Jonas, O.H.; Shental, N.; Nejman, D.; Gavert, N.; Zwang, Y.; Cooper, Z.A.; Shee, K.; et al. Potential role of intratumoral bacteria in mediating tumor resistance to the chemotherapeutic drug gemcitabine. Science 2017, 357, 1156-1160. [CrossRef] [PubMed]

272. Nilsson, H.O.; Stenram, U.; Ihse, I.; Wadstrom, T. Helicobacter species ribosomal DNA in the pancreas, stomach and duodenum of pancreatic cancer patients. World J. Gastroenterol. 2006, 12, 3038-3043. [CrossRef]

273. Wei, M.-Y.; Shi, S.; Liang, C.; Meng, Q.-C.; Hua, J.; Zhang, Y.-Y. The microbiota and microbiome in pancreatic cancer: More influential than expected. Mol. Cancer 2019, 18, 97. [CrossRef]

274. Manes, G.; Balzano, A.; Vaira, D. Helicobacter pylori and pancreatic disease. JOP 2003, 4, 111-116.

275. Di Magliano, M.P.; Logsdon, C.D. Roles of KRAS in pancreatic tumor development and progression. Gastroenterology 2013, 144, 1220-1229. [CrossRef]

276. Huang, H.; Daniluk, J.; Liu, Y.; Chu, J.; Li, Z.; Ji, B.; Logsdon, C.D. Oncogenic K-Ras requires activation for enhanced activity. Oncogene 2014, 33, 532-535. [CrossRef]

277. Lesina, M.; Kurkowski, M.U.; Ludes, K.; Rose-John, S.; Treiber, M.; Klöppel, G.; Yoshimura, A.; Reindl, W.; Sipos, B.; Akira, S.; et al. Stat3/Socs3 activation by IL-6 transsignaling promotes progression of pancreatic intraepithelial neoplasia and development of pancreatic cancer. Cancer Cell 2011, 19, 456-469. [CrossRef] [PubMed]

278. Gaiser, R.A.; Halimi, A.; Alkharaan, H.; Lu, L.; Davanian, H.; Healy, K.; Hugerth, L.W.; Ateeb, Z.; Valente, R.; Moro, C.F.; et al. Enrichment of oral microbiota in early cystic precursors to invasice pancreatic cancer. Gut 2019, 68, 2186-2194. [CrossRef] [PubMed]

279. Michaud, D.S.; Izard, J.; Wilhelm-Benartzi, C.S.; You, D.-H.; Grote, V.A.; Tjønneland, A.; Dahm, C.C.; Overvad, K.; Jenab, M.; Fedirko, V.; et al. Plasma antibodies to oral bacteria and risk of pancreatic cancer in a large European prospective cohort study. Gut 2013, 62, 1764-1770. [CrossRef]

280. Fan, X.; Alekseyenko, A.V.; Wu, J.; Peters, B.A.; Jacobs, E.J.; Gapstur, S.M.; Purdue, M.P.; Abnet, C.C.; Stolzenberg-Solomon, R.; Miller, G.; et al. Human oral microbiome and prospective risk for pancreatic cancer: A population-based nested case-control study. Gut 2018, 67, 120-127. [CrossRef]

281. Sinn, B.V.; Striefler, J.K.; Rudl, M.A.; Lehmann, A.; Bahra, M.; Denkert, C.; Sinn, M.; Stieler, J.; Klauschen, F.; Budczies, J.; et al. KRAS mutations in codon 12 or 13 are associated with worse prognosis in pancreatic ductal adenocarcinoma. Pancreas 2014, 43, 578-583. [CrossRef]

282. Ogrendik, M. Periodontal pathogens in the etiology of pancreatic cancer. Gastrointest. Tumor. 2017, 3, 125-127. [CrossRef]

283. Aliyu, S.H.; Marriott, R.K.; Curran, M.D.; Parmar, S.; Bentley, N.; Brown, N.M.; Brazier, J.S.; Ludlam, H. Real-time PCR investigation into the importance of Fusobacterium necropharum as a cause of acute pharyngitis in general practice. J. Med. Microbiol. 2004, 53, 1029-1035. [CrossRef]

284. Kostic, A.D.; Chun, E.; Robertson, L.; Glickman, J.N.; Gallini, C.A.; Michaud, M.; Clancy, T.E.; Chung, D.C.; Lochhead, P.; Hold, G.L.; et al. Fusobacterium nucleatum potentiates intestinal tumorigenesis and modulates the tumor-immune microenvironment. Cell Host Microb. 2013, 14, 207-215. [CrossRef]

285. Sethi, V.; Vitiello, G.A.; Saxena, D.; Miller, G.; Dudeja, V. The role of the microbiome in immunologic development and its implication for pancreatic cancer immunotherapy. Gastroenterology 2019, 156, 2097-2115. [CrossRef]

286. Riquelme, E.; Zhang, Y.; Zhang, L.; Montiel, M.; Zoltan, M.; Dong, W.; Quesada, P.; Sahin, I.; Chandra, V.; San Lucas, A.; et al. Tumor microbiome diversity and composition influence pancreatic cancer outcomes. Cell 2019, 178, 795-806. [CrossRef] [PubMed]

287. Aronsson, L.; Anderson, R.; Ansari, D. Intraductal papillary mucinous neoplasm of the pancreas-Epidemiology, risk factors, diagnosis, and management. Scand. J. Gastroenterol. 2017, 52, 803-815. [CrossRef]

288. Chandawani, R.; Allen, P.J. Cystic neoplasms of the pancreas. Annu. Rev. Med. 2016, 67, 45-57. [CrossRef]

289. Meng, C.; Bai, C.; Brown, T.D.; Hood, L.E.; Tian, Q. Human gut microbiota and gastrointestinal cancer. Genom. Proteom. Bioinform. 2018, 16, 33-49. [CrossRef] 
290. Ponziani, F.R.; Gerardi, V.; Pecere, S.; D’Aversa, F.; Lopetuso, L.; Zocco, M.A.; Pompili, M.; Gasbarrini, A. Effect of rifaximin on gut microbiota composition in advanced liver disease and its complications. World J. Gastroenterol. 2015, 21, 12322-12333. [CrossRef] [PubMed]

291. Grat, M.; Wronka, K.M.; Krasnodebski, M.; Masior, Ł.; Lewandowski, Z.; Kosińska, I.; Grąt, K.; Stypułkowski, J.; Rejowski, S.; Wasilewicz, M.; et al. Profile of gut microbiota associated with the presence of hepatocellular cancer in patients with liver cirrhosis. Transplant. Proc. 2016, 48, 1687-1691. [CrossRef]

292. Ponziani, F.R.; Bhoori, S.; Castelli, C.; Putignani, L.; Rivoltini, L.; Del Chierico, F.; Sanguinetti, M.; Morelli, D.; Sterbini, F.P.; Petito, $\mathrm{V}$; et al. Hepatocellular carcinoma is associated with gut microbiota profile and inflammation in nonalcoholic fatty liver disease. Hepatology 2019, 69, 107-120. [CrossRef] [PubMed]

293. Ren, Z.; Li, A.; Jiang, J.; Zhou, L.; Yu, Z.; Lu, H.; Xie, H.; Chen, X.; Shao, L.; Zhang, R.; et al. Gut microbiome analysis as a tool towards targeted non-invasive biomarkers for early hepatocellular carcinoma. Gut 2019, 68, 1014-1023. [CrossRef] [PubMed]

294. Huang, Y.; Fan, X.-G.; Wang, Z.M.; Zhou, J.H.; Tian, X.-F.; Li, N. Identification of helicobacter species in human liver samples from patients with primary hepatocellular carcinoma. J. Clin. Pathol. 2004, 57, 1273-1277. [CrossRef] [PubMed]

295. Dore, M.P.; Realdi, G.; Mura, D.; Graham, D.Y.; Sepulveda, A.R. Helicobacter infection in patients with HCV-related chronic hepatitis, cirrhosis, and hepatocellular carcinoma. Dig. Dis. Sci. 2002, 47, 1638-1643. [CrossRef]

296. Zhou, D.; Wang, J.D.; Weng, M.Z.; Zhang, Y.; Wang, X.-F.; Gong, W.; Quan, Z.-W. Infections of Helicobacter spp. in the biliary system are associated with biliary tract cancer: A meta-analysis. Eur. J. Gastroenterol. Hepatol. 2013, 25, 447-454. [CrossRef]

297. Lu, H.; Ren, Z.; Li, A.; Zhang, H.; Jiang, J.; Xu, S.; Luo, Q.; Zhou, K.; Xiaoli Sun, X.; Zheng, S.; et al. Deep sequencing reveals microbiota dysbiosis of tongue coat in patients with liver carcinoma. Sci. Rep. 2016, 6, 33142. [CrossRef] [PubMed]

298. Ponziani, F.R.; Nicoletti, A.; Gasbarrini, A.; Pompili, M. Diagnostic and therapeutic potential of the gut microbiota in patients with early hepatocellular carcinoma. Therap. Adv. Med. Oncol. 2019, 11, 1-6. [CrossRef] [PubMed]

299. Hartmann, P.; Chu, H.; Duan, Y.; Schnabl, B. Gut microbiota in liver disease: Too much is harmful, nothing at all is not helpful either. Am. J. Physiol Gastrointest. Liver. Physiol. 2019, 316, G563-G573. [CrossRef]

300. Mima, K.; Baba, H. The gut microbiome, antitumor immunity, and liver cancer. HepatoBiliary Surg. Nutr. 2019, 8, 67-68. [CrossRef] [PubMed]

301. Dapto, D.H.; Mencin, A.; Gwak, G.-Y.; Pradere, J.-P.; Jang., M.-K.; Mederacke, I.; Caviglia., J.M.; Khiabanian, H.; Adeyemi, A.; Bataller, R.; et al. Promotion of hepatocellular carcinoma by the intestinal microbiota and TLR4. Cancer Cell 2012, 21, 504-516. [CrossRef]

302. Jiang, J.-W.; Chen, X.-H.; Ren, Z.; Zheng, S.-S. Gut microbial dysbiosis associates hepatocellular carcinoma via the gut-liver axis. Hepatobil. Pancreat. Dis. Intern. 2019, 18, 19-27. [CrossRef]

303. Jia, B. Commentary: Gut microbiome-mediated bile acid metabolism regulates liver cancer via NKT cells. Front. Immunol. 2019, 10, 282. [CrossRef]

304. Jia, B.; Jeon, C.O. Promotion and induction of liver cancer by gut microbiome-mediated modulation of bile acids. PLoS Pathog. 2019, 15, e1007954. [CrossRef]

305. Loo, T.M.; Kamachi, F.; Watanabe, Y.; Yoshimoto, S.; Kanda, H.; Arai, Y.; Nakajima-Takagi, Y.; Iwama, A.; Koga, T.; Sugimoto, Y.; et al. Gut microbiota promotes obesity-associated liver cancer through $\mathrm{PGE}_{2}$-mediated suppression of antitumor immunity. Cancer Dis. 2017, 7, 522-538. [CrossRef]

306. Ipe, D.S.; Sundac, L.; Benjamin, W.H., Jr.; Moore, K.H.; Ulett, G.C. Asymptomatic bacteuria: Prevalence rates of causal microorganisms, etiology of infection in different patient populations, and recent advances in molecular detection. FEMS Microbiol. Lett. 2013, 346, 1-10. [CrossRef]

307. Aragón, J.M.; Herrera-Imbroda, B.; Queipo-Ortuño, M.; Castillo, E.; Del Moral, J.S.-G.; Gómez-Millán, J.; Yucel, G.; Lara, M.F. The urinary tract microbiome in health and disease. Eur. Urol. Focus. 2018, 4, 128-138. [CrossRef] [PubMed]

308. Bučević Popović, V.; Šitum, M.; Chow, C.-E.T.; Chan, L.S.; Roje, B.; Terzić, J. The urinary microbiome associated with bladder cancer. Sci. Rep. 2018, 8, 12157. [CrossRef]

309. Kamat, A.M.; Hahn, N.M.; Efstathiou, J.A.; Lerner, S.P.; Malmström, P.-U.; Choi, W.; Guo, C.C.; Lotan, Y.; Kassouf, W. Bladder cancer. Lancet 2016, 388, 2796-2810. [CrossRef]

310. Wu, P.; Zhang, G.; Zhao, J.; Chen, J.; Chen, Y.; Huang, W.; Zhong, J.; Zeng, J. Profiling the urinary microbiota in male patients with bladder cancer in China. Front. Cell Infect. Microbiol. 2018, 8, 167. [CrossRef]

311. Bi, H.; Tian, Y.; Song, C.; Li, J.; Liu, T.; Chen, Z.; Chen, C.; Huang, Y.; Zhang, Y. Urinary microbiota-A potential biomarker and therapeutic target for bladder cancer. J. Med. Microbiol. 2019, 68, 1471-1478. [CrossRef]

312. Pevsner-Fischer, M.; Tuganbaev, T.; Meijer, M.; Zhang, S.-H.; Zeng, Z.-R.; Chen, M.-H.; Elinav., E. Role of microbiome in non-gastrointestinal cancers. World J. Clin. Oncol. 2016, 7, 200-213. [CrossRef] [PubMed]

313. Whiteside, S.A.; Razvi, H.; Dave, S.; Reid, G.; Burton, J.P. The microbiome of the urinary tract-A role beyond infection. Nat. Rev. Urol. 2015, 12, 81-91. [CrossRef]

314. Banerjee, S.; Tian, T.; Wei, Z.; Shih, N.; Feldman, M.D.; Alwine, J.C.; Coukos, G.; Robertson, E.S. The ovarian cancer oncobiome. Oncotarget 2017, 8, 36225-36245. [CrossRef]

315. Miao, R.; Badger, T.C.; Groesch, K.; Diaz-Sylwester, P.L.; Wilson, T.; Ghareeb, A.; Martin, J.A.; Cregger, M.; Welge, M.; Bushell, C.; et al. Assessment of peritoneal microbial features and tumor marker levels as potential diagnostic tools for ovarian cancer. $P L o S$ ONE 2020, 15, e0227707. [CrossRef] 
316. Farolfi, A.; Gurioli, G.; Fugazzola, P.; Burgio, S.L.; Casanova, C.; Ravaglia, G.; Altavilla, A.; Costantini, M.; Amadori, A.; Framarini, M.; et al. Immune system and DNA repair defects in ovarian cancer: Implications for locoregional approaches. Int. J. Mol. Sci. 2019, 20, 2569. [CrossRef]

317. Nakamura, M.; Bax, H.J.; Scotto, D.; Souri, E.A.; Sollie, S.; Harris, R.J.; Hammar, N.; Walldius, G.; Winship, A.; Ghosh, S.; et al. Immune mediator expression signatures are associated with improved outcome in ovarian carcinoma. Oncoimmunology 2019, 8, e1593811. [CrossRef] [PubMed]

318. Idahl, A.; Lundin, E.; Jurstrand, M.; Kumlin, U.; Elgh, F.; Ohlson, N.; Ottander, U. Chlamydia trachomatis and Mycoplasma genitalium plasma antibodies in relation to epithelial ovarian tumors. Infect. Dis. Obstet. Gynecol. 2011, $1011,824627$.

319. Baker, J.M.; Al-Nakkash, L.; Herbst-Kralovetz, M.M. Estrogen-gut microbiome axis: Physiological and clinical implications. Maturitas 2017, 103, 45-53. [CrossRef]

320. Bhatt, A.P.; Redinbo, M.R.; Bultman, S.J. The role of the microbiome in cancer development and therapy. CA Cancer J. Clin. 2017, 67, 326-344. [CrossRef]

321. Ibrahim, Y.M.A.; Emara, M.; Vyas, V.; al Awadi, S.; Jaroslav, N.; el Khodry, A.; Essam, T.; Rouf, Y.M.A.; Amanguno, H.; Purohit, P. Synchronous occurrence of brucellosis and ovarian cancer-A case report. Austral-Asian. J. Cancer. 2007, 6, $257-259$.

322. Chan, P.J.; Seraj, I.M.; Kalugdan, T.H.; King, A. Prevalence of mycoplasma conserved DNA in malignant ovarian cancer detected using sensitive PCR-ELISA. Gynecol. Oncol. 1996, 63, 258-260. [CrossRef]

323. Shanmughapriya, S.; Senthilkumar, G.; Vinodhini, K.; Das, B.C.; Vasanthi, N.; Natarajaseenivasan, K. Viral and bacterial aetologies of epithelial ovarian cancer. Eur. J. Clin. Microbiol. Infect. Dis. 2012, 31, 2311-2317. [CrossRef]

324. Nené, N.R.; Reisel, D.; Leimbach, A.; Franchi, D.; Jones, A.; Evans, I.; Knapp, S.; Ryan, A.; Ghozali, S.; Timms, J.F.; et al. Association between the cervicovaginal microbiome, BRCA1 mutation status, and risk of ovarian cancer: A case-control study. Lancet Oncol. 2019, 20, 1171-1182. [CrossRef]

325. Ravel, J.; Gajer, P.; Abdo, Z.; Schneider, G.M.; Koenig, S.S.K.; McCulle, S.L.; Karlebach, S.; Gorle, R.; Russell, J.; Tacket, C.O.; et al. Vaginal microbiome of reproductive-age women. Proc. Natl. Acad. Sci. USA 2011, 108 (Suppl. S1), 4680-4687. [CrossRef] [PubMed]

326. Arbyn, M.; Tommasino, M.; Depuydt, C.; Dillner, J. Are 20 human papillomavirus types causing cervical cancer? J. Pathol. 2014, 234, 431-435. [CrossRef]

327. Gao, W.; Weng, J.; Gao, Y.; Chen, X. Comparison of the vaginal microbiota diversity of women with and without human papillomavirus infection: A cross-sectional study. BMC Infect. Dis. 2013, 13, 271. [CrossRef]

328. Lee, J.E.; Lee, S.; Lee, H.; Song, Y.-M.; Lee, K.; Han, M.J.; Sung, J.; Ko, G.P. Association of the vaginal microbiota with human papillomavirus infection in a Korean twin cohort. PLoS ONE 2013, 8, e63514. [CrossRef]

329. Brotman, R.M.; Shardell, M.D.; Gajer, P.; Tracy, J.K.; Zenilman, J.M.; Ravel, J.; Gravitt, P.E. Interplay between the temporal dynamics of the vaginal microbiota and human papillomavirus detection. J. Infect. Dis. 2014, 210, 1723-1733. [CrossRef]

330. Silva, J.; Cerquiera, F.; Medeiros, R. Chlamydia trachomatis infections implications for HPV status and cervical cancer. Arch. Gynecol. Obstet. 2014, 289, 715-723. [CrossRef]

331. Seo, S.S.; Oh, H.Y.; Lee, J.K.; Kong, J.S.; Lee, D.O.; Kim, M.K. Combined effect of diet and cervical microbiome on the risk of cervical intraepithelial neoplasia. Clin. Nutr. 2016, 35, 1434-1441. [CrossRef]

332. Oh, H.Y.; Kim, B.S.; Seo, S.S.; Kong, J.-S.; Lee, J.-L.; Park, S.-Y.; Hong, K.-M.; Kim., H.-K.; Kim., M.K. The association of uterine cervical microbiota with an increased risk for cervical intraepithelial neoplasia in Korea. Clin. Microbiol. Infect. 2015, 21, e1-e674. [CrossRef]

333. Piyathilake, C.J.; Ollberding, N.J.; Kumar, R.; Macaluso, M.; Alvarez, R.D.; Morrow, C.D. Cervical microbiota associated with higher grade cervical intraepithelial neoplasia in women with high-risk human papillomaviruses. Cancer Prev. Rev. 2016, 9, 357-366. [CrossRef]

334. Audirac-Chalifour, A.; Torres-Poveda, K.; Bahena-Román, M.; Téllez-Sosa, J.; Martínez-Barnetche, J.; Cortina-Ceballos, B.; López-Estrada, G.; Delgado-Romero, K.; Burguete-García, A.I.; Cantú, D.; et al. Cervical microbiome and cytokine profile at various stages of cervical cancer: A pilot study. PLOS ONE 2016, 11, e0153274.

335. Champer, M.; Wong, A.M.; Champer, J.; Brito, I.L.; Messer, P.W.; Hou, J.Y.; Wright, J.D. The role of the vaginal microbiome in gynecological cancer. BJOG 2018, 125, 309-315. [CrossRef]

336. Massari, F.; Mollica, V.; Di Nunno, V.; Gatto, L.; Santoni, M.; Scarpelli, M.; Cimadamore, A.; Lopez-Beltran, A.; Cheng, L.; Battelli, N.; et al. The human microbiota and prostate cancer: Friend or foe. Cancers 2019, 11, 459. [CrossRef] [PubMed]

337. Palapattu, G.S.; Sutcliffe, S.; Bastian, P.; Platz, E.A.; De Marzo, A.M.; Isaacs, W.B.; Nelson, W.G. Prostate carcinogenesis and inflammation: Emerging insights. Carcinogenesis 2005, 26, 1170-1181. [CrossRef]

338. Lax, A.J.; Thomas, W. How bacteria could cause cancer: One step at a time. Trends Microbiol. 2002, 10, 293-299. [CrossRef]

339. Wei, H.; Dong, L.; Wang, T.; Zhang, M.; Hua, W.; Zhang, C.; Pang, X.; Chen, M.; Su, M.; Qiu, Y.; et al. Structural shifts of gut microbiota as surrogate, endpoints for monitoring host health changes induced by carcinogen exposure. FEMS Microbiol. Ecol. 2010, 73, 577-586. [CrossRef]

340. Liss, M.A.; White, J.R.; Goros, M.; Gelfond, J.; Leach, R.; Johnson-Pais, T.; Lai, Z.; Rourke, E.; Basler, J.; Ankerst, D.; et al. Metabolic biosynthesis pathways identified from fecal microbiome associated with prostate cancer. Eur. Urol. 2018, 74, 575-582. [CrossRef]

341. Cavarretta, I.; Ferrarese, R.; Cazzaniga, W.; Saita, D.; Lucianò, R.; Ceresola, E.R.; Locatelli, I.; Visconti, L.; Lavorgna, G.; Briganti, A.; et al. The microbiome of the prostate tumor microenvironment. Eur. Urol. 2017, 72, 625-631. [CrossRef] 
342. Cimadamore, A.; Santoni, M.; Massari, F.; Gasparrini, S.; Cheng, L.; Lopez-Beltran, A.; Montironi, R.; Scarpelli, M. Microbiome and cancers with focus on genitourinary tumors. Front. Oncol. 2019, 9, 178. [CrossRef]

343. Miyake, M.; Ohnishi, K.; Hori, S.; Nakano, A.; Nakano, R.; Yano, H.; Ohnishi, S.; Owari, T.; Morizawa, Y.; Itami, Y.; et al. Mycoplasma genitalium infection and chronic inflammation in human prostate cancer: Detection using prostatectomy and needle biopsy specimens. Cells 2019, 8, 212. [CrossRef]

344. Wheeler, K.M.; Liss, M.A. The microbiome and prostate cancer risk. Curr. Urol. Rep. 2019, 20, 66. [CrossRef]

345. Yu, H.; Meng, H.; Zhou, F.; Ni, X.; Shen, S.; Das, U.N. Urinary microbiota in patients with prostate cancer and benign prostatic hyperplasia. Arch. Med. Sci. 2015, 11, 385-394. [CrossRef] [PubMed]

346. Liu, F.; Li, J.; Guan, Y.; Lou, Y.; Chen, H.; Xu, M.; Deng, D.; Chen, J.; Ni, B.; Zhao, L.; et al. Dysbiosis of the gut microbiome is associated with tumor biomarkers in lung cancer. Int. J. Biol. Sci. 2019, 15, 2381-2392. [CrossRef]

347. Jin, C.; Lagoudas, G.K.; Zhao, C.; Bullman, S.; Bhutkar, A.; Hu, B.; Ameh, S.; Sandel, D.; Liang, X.S.; Mazzilli, S.; et al. Commensal microbiota promote lung cancer development via $\gamma \delta$ T cells. Cell 2019, 176, 998-1013. [CrossRef] [PubMed]

348. Kovaleva, O.V.; Romashin, D.; Zborovskaya, I.B.; Davydov, M.M.; Shogenov, M.S.; Gratchev, A. Human lung microbiome on the way to cancer. J. Immunol. Res. 2019, 2019, 1394191. [CrossRef] [PubMed]

349. Sommariva, M.; Le Noci, V.; Bianchi, F.; Camelliti, S.; Balsari, A.; Tagliabue, E.; Sfondrini, S. The lung microbiota: Role in maintaining pulmonary immune homeostasis and its implications in cancer development and therapy. Cell Mol. Life Sci. 2020, 77, 2739-2749. [CrossRef]

350. Morris, A.; Beck, J.M.; Schloss, P.D.; Campbell, T.B.; Crothers, K.; Curtis, J.L.; Flores, S.C.; Fontenot, A.P.; Ghedin, E.; Huang, L.; et al. Comparison of the respiratory microbiome in healthy nonsmokers and smokers. Am. J. Resp. Crit. Care Med. 2013, 187, 1067-1075. [CrossRef]

351. Dickson, R.P.; Erb-Downward, J.R.; Martinez, F.J.; Huffnagle, G.B. The microbiome and the respiratory tract. Annu. Rev. Physiol. 2016, 78, 481-504. [CrossRef]

352. Beck, J.M.; Young, V.B.; Huffnagle, G.B. The microbiome of the lung. Transl. Res. 2012, 160, 258-266. [CrossRef]

353. Huang, D.; Su, X.; Yuan, M.; Zhang, S.; He, J.; Deng, Q.; Qiu, W.; Dong, H.; Cai, S. The characterization of lung microbiome in lung cancer patients with different clinicopathology. Am. J. Cancer Res. 2019, 9, 2047-2063.

354. Greathouse, K.L.; White, J.R.; Vargas, A.J.; Bliskovsky, V.V.; Beck, J.A.; von Muhlinen, N.; Polley, E.C.; Bowman, E.D.; Khan, M.A.; Robles, A.I.; et al. Interaction between the microbiome and TP53 in human lung cancer. Genome Biol. 2018, 19, 123. [CrossRef] [PubMed]

355. Erb-Downward, J.R.; Thompson, D.L.; Han, M.K.; Freeman, C.M.; McCloskey, L.; Schmidt, L.A.; Young, V.B.; Toews, G.B.; Curtis, J.L.; Sundaram, B.; et al. Analysis of the lung microbiome in the "healthy" smoker and in COPD. PLoS ONE 2011, 6, e16384. [CrossRef]

356. Yan, X.; Yang, M.; Liu, J.; Gao, R.; Hu, J.; Li, J.; Zhang, L.; Shi, Y.; Guo, H.; Cheng, J.; et al. Discovery and validation of potential bacterial biomarkers for lung cancer. Am. J. Cancer Res. 2015, 5, 3111-3122.

357. Cameron, S.J.S.; Lewis, K.E.; Huws, S.A.; Hegarty, M.J.; Lewis, P.D.; Pachebat, J.A.; Mur, L.A.J. A pilot study using metagenomics sequencing of the spectrum microbiome suggests potential bacterial biomarkers for lung cancer. PLoS ONE 2017, 12, 0177062. [CrossRef]

358. Liu, Y.; O’Brien, J.L.; Ajami, N.J.; Scheurer, M.E.; Amirian, E.S.; Armstrong, G.; Tsavachidis, S.; Thrift, A.P.; Jiao, L.; Wong, M.C.; et al. Lung tissue microbial profile in lung cancer is distinct from emphysema. Am. J. Cancer Res. 2018, 8, $1775-1787$.

359. Zhuang, H.; Cheng, L.; Wang, Y.; Zhang, Y.-K.; Zhao, M.-F.; Liang, G.-D.; Zhang, M.-C.; Li., Y.-G.; Zhao, J.-B.; Gao., Y.-N.; et al. Dysbiosis of the gut microbiome in lung cancer. Front. Cell Infect. Microbiol. 2019, 9, 112. [CrossRef]

360. Gomes, S.; Cavadas, B.; Ferreira, J.C.; Marques, P.I.; Monteiro, C.; Sucena, M.; Sousa, C.; Rodrigues, L.V.; Teixeira, G.; Pinto, P.; et al. Profiling of lung microbiota discloses differences in adenocarcinoma and squamous cell carcinoma. Sci. Rep. 2019, 9, 12838. [CrossRef]

361. Krief, J.O.; de Tauries, P.H.; Dumenil, C.; Neveux, N.; Dumoulin, J.; Giraud, V.; Labrune, S.; Tisserand, J.; Julie, C.; Emile, J.-F.; et al. Role of antibiotic use, plasma citruline and blood microbiome in advanced non-small cell lung cancer patients treated with nivolumab. J. Immunol. Ther. Cancer 2019, 7, 176.

362. Plaza-Diaz, J.; Alvarez-Mercado, A.I.; Ruiz-Marín, C.M.; Reina-Pérez, I.; Pérez-Alonso, A.J.; Sánchez-Andujar, M.B.; Torné, P.; Gallart-Aragón, T.; Sánchez-Barrón, M.T.; Lartategui, S.R.; et al. Association of breast and gut microbiota dysbiosis and risk of breast cancer: A case-control clinical study. BMC Cancer 2019, 19, 495. [CrossRef]

363. Bingula, R.; Filaire, M.; Radosevic-Robin, N.; Berthon, J.-Y.; Bernalier-Donadille, A.; Vasson, M.-P.; Thivat, E.; Kwiatkowski, F.; Filaire., E. Characterisation of gut, lung, and upper airways microbiota in patients with non-small cell lung carcinoma. Study protocol for case-control observational trial. Medicine 2018, 97, e13676. [CrossRef]

364. Liu, H.X.; Tao, L.L.; Zhang, J.; Zhu, Y.-G.; Zheng, Y.; Liu, D.; Zhou, M.; Ke, H.; Shi, M.-M.; Qu., J.-M. Difference of lower airway microbiome in bilateral protected specimen brush between lung cancer patients with unilateral lobar masses and control subjects. Int. J.Cancer 2018, 142, 769-778. [CrossRef]

365. Peters, B.A.; Hayers, R.B.; Goparaju, C.; Reid, C.; Pass, H.I.; Ahn, J. The microbiome in lung cancer tissue and recurrence-free survival. Cancer Epidemiol. Biomark. Prev. 2019, 28, 731-740. [CrossRef] 
366. Stevenson, A.; Panzica, A.; Holt, A.; Caly, D.L.; Ettore, A.; Delday, M.; Hennessy, E.; Cowie, P.; Pradhan, M.; Jeffery, I.; et al. Host-microbe interactions mediating antitumorigenic effects of MRX01518, a gut microbiota-derived bacterial strain, in breast, renal and lung carcinoma. J. Clin. Oncol. 2018, 36, e15006. [CrossRef]

367. Maddi, A.; Sabharwal, A.; Violante, T.; Manuballa, S.; Genco, R.; Patnaik, S.; Yendamuri, S. The microbiome and lung cancer. J. Thorac. Dis. 2019, 11, 280-291. [CrossRef]

368. Kong, H.H.; Segre, J.A. The molecular evolution in cutaneous biology: Investigating the skin microbiome. J. Investig. Dermatol. 2017, 137, e119-e122. [CrossRef]

369. Thomas, C.L.; Fernández-Peñas, P. The microbiome and atopic eczema: More than skin deep. Austral. J. Dermatol. 2017, 58, 18-24. [CrossRef]

370. Paller, A.S.; Kong, H.H.; Seed, P.; Naik, S.; Scharschmidt, T.C.; Gallo, R.L.; Luger, T.; Irvine, A.D. The microbiome in patients with atopic dermatitis. J. Allergy Clin. Immunol. 2019, 143, 26-35. [CrossRef]

371. Shi, B.; Bangayan, N.J.; Curd, E.; Taylor, P.A.; Gallo, R.L.; Leung, D.Y.M.; Li, H. The skin microbiome is different in pediatric versus adult atopic dermatitis. J. Allerg. Clin. Immunol. 2016, 138, 1233-1236. [CrossRef]

372. Peters, B.A.; Wilson, M.; Moran, U.; Pavlick, A.; Izsak, A.; Wechter, T.; Weber, J.S.; Osman, I.; Ahn, J. Relating the gut metagenome and metatranscriptome to immunotherapy responses in melanoma patients. Genome Med. 2019, 11, 61. [CrossRef] [PubMed]

373. Urbaniak, C.; Gloor, G.B.; Brackstone, M.; Scott, L.; Tangney, M.; Reid, G. The microbiota of breast tissue and its association with breast cancer. Appl. Envir. Microbiol. 2016, 82, 5039-5048. [CrossRef] [PubMed]

374. Constantini, L.; Magno, S.; Albanese, D.; Donati, C.; Molinari, R.; Filippone, A.; Masetti, R.; Merendino, N. Characterization of human breast tissue microbiota from core needle biopsies through the analysis of multivariable 16S-rRNA gene regions. Sci. Rep. 2018, 8, 16893. [CrossRef]

375. Eslami-S, Z.; Majidzadeh-A, K.; Halvaei, S.; Babapirali, F.; Esmaeili, R. Microbiome and breast cancer: New role for an ancient population. Front. Oncol. 2020, 10, 120. [CrossRef]

376. Hieken, T.J.; Chen, J.; Hoskin, T.L.; Walther-Antonio, M.; Johnson, S.; Ramaker, S.; Xiao, J.; Radisky, D.C.; Knutson, K.L.; Kalari, K.R.; et al. The microbiome of aseptically collected human breast tissue in benign and malignant disease. Sci. Rep. 2016, 6, 30751. [CrossRef]

377. Wang, H.; Altemus, J.; Niazi, F.; Green, H.; Calhoun, B.C.; Sturgis, C.; Grobmyer, S.R.; Eng, C. Breast tissue, oral and urinary microbiomes in breast cancer. Oncotarget 2017, 8, 88122-88138. [CrossRef]

378. Mikó, E.; Kovács, T.; Sebö, É.; Tóth, J.; Csonka, T.; Ujlaki, G.; Sipos, A.; Szabó, J.; Méhes, G.; Bai, P. Microbiome-microbial metabolome-cancer cell interaction in breast cancer-familiar, but unexpected. Cells 2019, 8, 293. [CrossRef]

379. Ingman, M.V. The gut microbiome: A new player in breast cancer metastasis. Cancer Res. 2019, 79, 3539-3541. [CrossRef] [PubMed]

380. McKee, A.M.; Hall, L.J.; Robinson, S.D. The microbiota, antibiotics and breast cancer. Breast Canc. Manag. 2019, 8, 3. [CrossRef] [PubMed]

381. Marschalek, J.; Farr, A.; Marschalek, M.-L.; Domig, K.J.; Kneifel, W.; Singer, C.F.; Kiss, H.; Petricevic, L. Influence of orally administered probiotic Lactobacillus strains on vaginal microbiota in women with breast cancer during chemotherapy: A randomized placebo-controlled double-blinded pilot study. Breast Care 2017, 12, 335-339. [CrossRef]

382. Singh, A.; Nayak, N.; Rathi, P.; Verma, D.; Sharma, R.; Chaudhary, A.; Agarwal, A.; Tripathi, Y.B.; Gang, N. Microbiome and host cross-link: A new paradigm to cancer therapy. Sem. Cancer Biol. 2021, 70, 71-84. [CrossRef]

383. Lau, H.C.H.; Sung, J.J.-Y.; Yu, J. Gut microbiota: Impacts on gastrointestinal cancer immunotherapy. Gut Microbiol. 2021, 13, e1869504. [CrossRef]

384. Chandra, V.; McAllister, F. Therapeutic potential of microbial modulation in pancreatic cancer. Gut 2021, 70, 1419-1425. [CrossRef]

385. Pliszka, M.; Szablewski, L. Glucose transporters as a target for anticancer therapy. Cancers 2021, 13, 4184. [CrossRef]

386. McCarthy, E.F. The toxins of William, B Coley and the treatment of bone and soft-tissue sarcomas. Iowa Orthop. 2006, 26, 154-158.

387. Mellman, I.; Coukos, G.; Dranoff, G. Cancer immunotherapy comes of age. Nature 2011, 480, 480-489. [CrossRef]

388. Kiselyov, A.; Bunimovich-Mendrazitsky, S.; Startsev, V. Treatment of non-muscle invasive bladder cancer with Bacillus CalmetteGuerin (BCG): Biological markers and stimulation studies. BBA Clin. 2015, 4, 27-34. [CrossRef]

389. Le, D.T.; Wang-Gillam, A.; Picozzi, V.; Greten, T.F.; Crocenzi, T.; Springett, G.; Morse, M.; Zeh, H.; Cohen, D.; Fine, R.L.; et al. Safety and survival with GVAX pancreas prime and Listeria monocytogenes-expressing mesothelin (CRS-207) boost vaccines for metastatic pancreatic cancer. J. Clin. Oncol. 2015, 33, 1325-1333. [CrossRef]

390. Gopalakrishnan, V.; Spencer, C.N.; Nezi, L.; Reuben, A.; Andrews, M.C.; Karpinets, T.V.; Prieto, P.A.; Vicente, D.; Hoffman, K.; Wei, S.C.; et al. Gut microbiome modulates response to anti-PD-1 immunotherapy in melanoma patients. Science 2018, 359, 97-103. [CrossRef]

391. Matson, V.; Fessler, J.; Bao, R.; Chongsuwat, T.; Zha, Y.; Alegre, M.-L.; Luke, J.J.; Gajewski, T.F. The commensal microbiome is associated with anti-PD-1 efficacy in metastatic melanoma patients. Science 2018, 359, 104-108. [CrossRef]

392. Routy, B.; Le Chatelier, E.; Derosa, L.; Duong, C.P.M.; Alou, M.T.; Daillère, R.; Fluckiger, A.; Messaoudene, M.; Rauber, C.; Roberti, M.P.; et al. Gut microbiome influences efficacy of PD-1 based immunotherapy against epithelial tumors. Science 2018, 359, 91-97. [CrossRef]

393. Ma, W.; Mao, Q.; Xia, W.; Dong, G.; Yu, C.; Jiang, F. Gut microbiota shapes the efficiency of cancer therapy. Front. Microbiol. 2019, 10, 1050. [CrossRef] 
394. Gharaibeh, R.Z.; Jobin, C. Microbiota and cancer immunotherapy: In search of microbial signals. Gut 2019, 68, 385-388. [CrossRef] [PubMed]

395. Alexander, J.L.; Wilson, I.D.; Teare, J.; Marchesi, J.R.; Nicholson, J.K.; Kinross, J.M. Gut microbiota modulation of chemotherapy efficacy and toxicity. Nat. Rev. Gastroenterol. Hepatol. 2017, 14, 356-365. [CrossRef] [PubMed]

396. Guthrie, L.; Gupta, S.; Daily, J.; Kelly, L. Human microbiome signatures of differential colorectal cancer drug metabolism. NPJ Biofilm. Microb. 2017, 3, 27. [CrossRef] [PubMed]

397. Villéger, R.; Lopés, A.; Carrier, G.; Veziant, J.; Billard, E.; Barnich, N.; Gagnière, J.; Vazeille, E.; Bonne, M. Intestinal microbiota: A novel target to improve anti-tumor treatment? Int. J. Mol. Sci. 2019, 20, 4584. [CrossRef]

398. Viaud, S.; Saccheri, F.; Mignot, G.; Yamazaki, T.; Daillère, R.; Hannani, D.; Enot, D.P.; Pfirschke, C.; Engblom, C.; Pittet, M.J.; et al The intestinal microbiota modulates the anticancer immune effects of cyclophosphamide. Science 2013, 342, 971-976. [CrossRef]

399. Gui, Q.; Lu, H.F.; Zhang, C.X.; Xu, Z.R.; Yang, Y.H. Well-balanced commensal microbiota contributes to anti-cancer response in a lung cancer mouse model. Genet. Mol. Res. 2015, 14, 5642-5651. [CrossRef]

400. Hendler, R.; Zhang, Y. Probiotics in treatment of colorectal cancer. Medicines 2018, 5, 101. [CrossRef] [PubMed]

401. Delia, P.; Sansotta, G.; Donato, V.; Frosina, P.; Messina, G.; De Renzis, C.; Famularo, G. Use of probiotic for prevention of radiation-induced diarrhea. World J. Gastroenterol. 2007, 13, 912-915. [CrossRef]

402. Demers, M.; Dagnault, A.; Desjardins, J. A randomized double-blind controlled trial: Impact of probiotics on diarrhea in patients treated with pelvic radiation. Clin. Nutr. 2014, 33, 761-767. [CrossRef]

403. Konishi, H.; Fujiva, M.; Tanaka, H.; Ueno, N.; Moriichi, K.; Sasajima, J.; Ikuta, K.; Akutsu, H.; Tanabe, H.; Kohgo, Y. Probioticderived ferrichrome inhibits colon cancer progression via JNK-mediated apoptosis. Nat. Commun. 2016, 7, 12365. [CrossRef]

404. Li, J.; Sung, C.Y.J.; Lee, N.; Ni, Y.; Pihlajamäki, J.; Panagiotou, G.; El-Nezami, H. Probiotics modulated gut microbiota suppresses hepatocellular carcinoma growth in mice. Proc. Natl. Acad. Sci. USA 2016, 113, E1306-E1315. [CrossRef]

405. Sivan, A.; Corrales, L.; Hubert, N.; Williams, J.B.; Aquino-Michaels, K.; Earley, Z.M.; Benyamin, F.W.; Lei, Y.M.; Jabri, B.; Alegre, M.-L.; et al. Commensal Bifidobacterium promotes antitumor immunity and facilitates anti-PD-L1 efficacy. Science 2015, 350, 1084-1089. [CrossRef]

406. Rea, D.; Coppola, G.; Palma, G.; Barbieri, A.; Luciano, A.; Del Prete, P.; Rossetti, S.; Berretta, M.; Facchini, G.; Perdonà, S.; et al. Microbiota effects on cancer: From risk to therapies. Oncotarget 2018, 9, 17915-17927. [CrossRef]

407. Sommacal, H.M.; Bersch, V.P.; Vitola, S.P.; Osvaldt, A.B. Perioperative synbiotics decrease postoperative complications in periampullary neoplasma: A randomized, double-blind clinical trial. Natur. Cancer 2015, 67, 457-462. [CrossRef]

408. Bel, S.; Elkis, Y.; Elifantz, H.; Koren, O.; Ben-Hamo, R.; Lerer-Goldshtein, T.; Rahimi, R.; Horin, S.B.; Nyska, A.; Shpungin, S.; et al. Reprogrammed and transmissible intestinal microbiota confer diminished susceptibility to induced colitis in $\mathrm{TMF}^{-} /^{-} \mathrm{mice}$ Proc. Natl. Acad. Sci. USA 2014, 111, 4964-4969. [CrossRef] 